\title{
Notice of Construction for Tank Waste Remediation System Vadose Zone Characterization
}

Prepared for the U.S. Department of Energy

Assistant Secretary for Environmental Management

U.S. Department of Energy under Contract DE-AC06-96RL13200

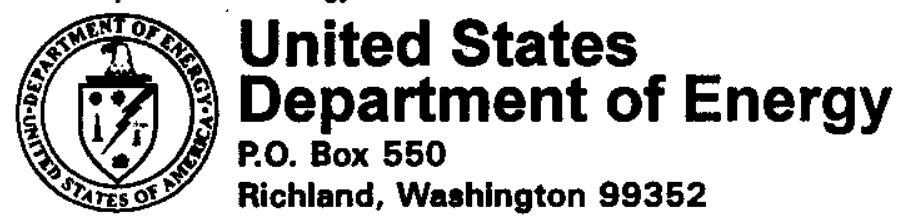

RECORD COPY 


\section{Notice of Construction for Tank Waste Remediation System Vadose Zone Characterization}

Prepared for the U.S. Department of Energy

Assistant Secretary for Environmental Management

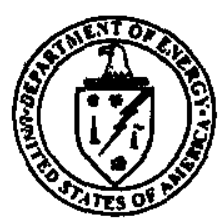

United States

Richland, Washington 99352 


\section{INFORMATION CLEARANCE FORM}

\begin{tabular}{|ll}
\hline \multicolumn{2}{|c|}{ A. Information Category } \\
$\square$ Abstract & $\square$ Journal Articto \\
$\square$ Summary & $\square$ Internet \\
$\square$ Visual Aid & $\square$ Software \\
$\square$ Full Paper. & $\square$ Report \\
$\square$ Other RAD NOC & \\
\hline
\end{tabular}
B. Document Number $B \mathrm{OE} / \mathrm{ORP}-2000-05, \mathrm{REV}, 1$
C. Tite
NOTICE OF CONSTRUCTION FOR TANK WASTE REMEDIATION SYSTEM VADOSE
ZONE CHARACTERIZATION, REV. 1

\section{Internet Address}

E. Required Information

1. Is document pefontlally Glapified? $\triangle$ No $\square$ Yes (MANDATORY) 10 tour

Manager's Signature Required

If Yes 7

ADC Signature Required

\No $\square$ Yes Classified

2. Internal Review Required?

If Yes, Document Slgnatures Below

No $\mathbf{X}$ Yes

Counsel

$-$

Program

3. References in the Information are Applied Technology $\bigotimes_{N O} \square$ Yes

Export Controlled Information

$\bigotimes_{\text {No }} \square$ Yes

4. Does Information Contain the Following: (MANDATORY)

a. New or Novel (Patentable) Subject Matter? $\triangle$ No $\square$ Yes

If "Yes", Disclosure No.:

b. Information Received in Confidence, Such as Proprietary and/or Inventions?

$\triangle$ No $\square$ Yes If "Yes", Affx Appropriate Legends/Notices.

c. Copyrights? $\square$ No $\square$ Yes If "Yes", Attach Permission.

d. Trademarks? $\square$ No $\bigotimes$ Yes If "Yes", Identfy in Document.

5. Is Information requiring submission to OSTI? $\square$ No $\square$ Yes

If Yes $U C-630$ and $B \& R-$

6. Release Level? $\square$ Public $\square$ Limited

7. Charge code 110173

F. Complete for a Journal Article

1. Titlo of Journal

G. Complete for a Presentation

1. Title for Conference or Meeting

2. Group Sponsoring

3. Date of Conference

5. Will Information be Published in Proceedinge? $\square$ No $\square$ Yes

4. City/State

H. Author/Requestor $\frac{\text { J. STAN HILL }}{\text { (Print and Sign) }}$

I. Reviowers

Yos Print

6. Will Material be Handed Out? $\square$ No $\square$ Yes

$\begin{array}{llll}\text { General Counsel } & \square \\ \text { Office of External Affairs } \square & \square \\ \text { DOE-RL } & \square\end{array}$

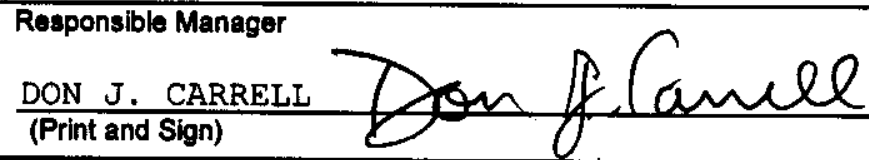

Signature

Public $\mathrm{Y} / \mathrm{N}$ (If $\mathrm{N}$, complete J)

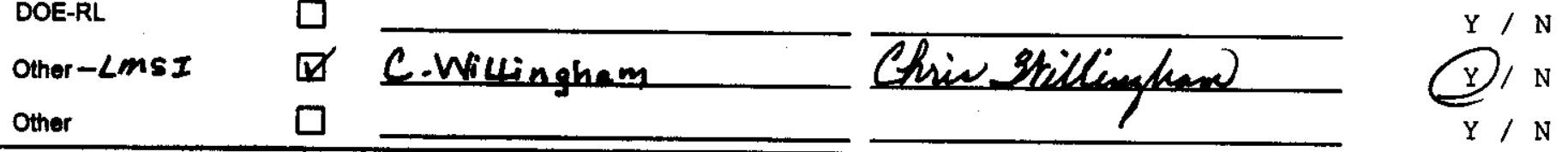

J. If Information Includes Eenaltive Information and is not to be released to the Public indicate category below.

$\square$ Applied Technology $\square$ Protected CRADA

$\square$ PersonalPivate $\square$ Export Controlled

$\square$ Proprietary

$\square$ Businese-Sensitive

$\square$ Procurement-Sensitive

$\square$ Predecisional

$\square$ Patentable

$\square$ UCNI

$\square$ Other (Specify)

K. If Additional Comments, Please Attach Separate Sheot

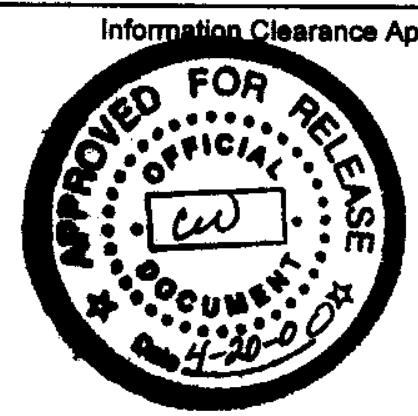




\section{RELEASE AUTHORIZATION}

Document DOE/ORP-2000-05, Rev. 1

Number:

Document Title: $\quad$ Notice of Construction for Tank Waste Remediation System Vadose Zone Characterization, Revision 1

This document, reviewed in accordance with DOE Order 241.1, "Scientific and Technical Information Management," and DOE G 241.1-1, "Guide to the Management of Scientific and Technical Information," does not contain classified or sensitive unclassified information and is:

\section{APPROVED FOR PUBLIC RELEASE}

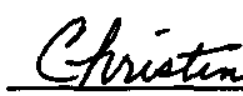

y.

isistin

C. Willingham

$4 / 20 / 00$

Lockheed Martin Services, Inc.

Document Control/nformation Clearance

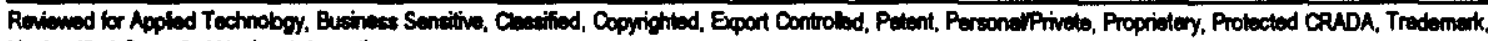
Unclessified Controlud Nucber hiormation.

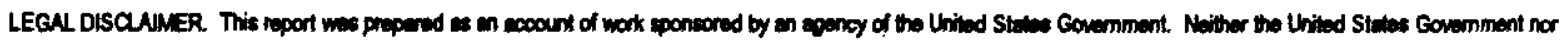

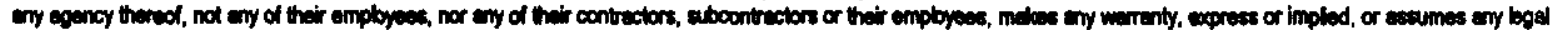

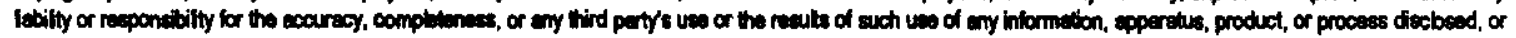

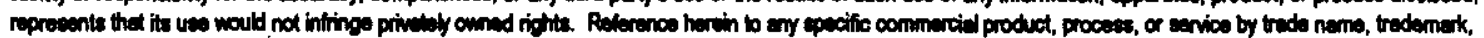

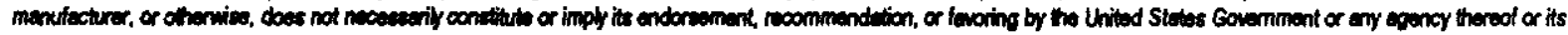

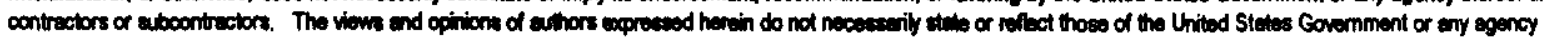
thereof. This report hes been reproduced from the best eveilebe copy. Printed in the Unitiod Statese of America. 


\section{Notice of Construction for Tank Waste Remediation System Vadose Zone Characterization}

Prepared for the U.S. Department of Energy

Assistant Secretary for Environmental Management

U.S. Department of Energy under Contract DE-AC06-96RL13200

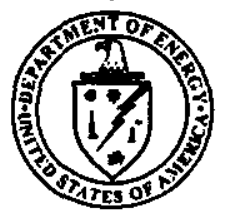

United States

Department of Energy

P.O. Box 550

Richland, Washington 99352 


\section{Notice of Construction for Tank Waste Remediation System Vadose Zone Characterization}

April 2000

Prepared for the U.S. Department of Energy Assistant Secretary for Environmental Management

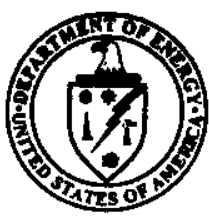

United States Department of Energy 


\section{RELEASE AUTHORIZATION}

Document

DOEJORP-2000-05, Rev. 1

Number:

Document THte: Notice of Construction for Tank Waste Remediation System Vadose Zone Characterization, Revision 1

This document, reviewed in accordance with DOE Order 241.1, "Scientific and Technical Information Management," and DOE G 241.1-1, "Guide to the Management of Scientific and Technical Information," does not contain classified or sensitive unclassified information and is:

\section{APPROVED FOR PUBLIC RELEASE}

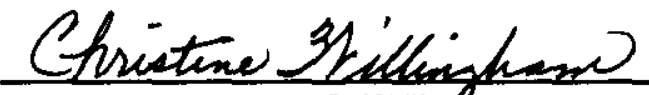

C. Willingtham

Lockheed Martin Services, Inc.

Document Control/nformation Clearance

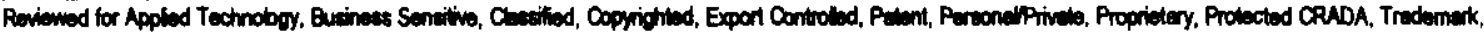
Unclestified Controlud Nucter information.

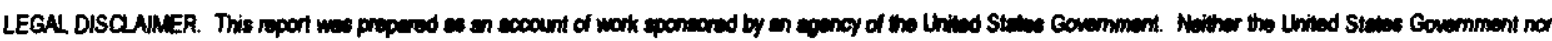

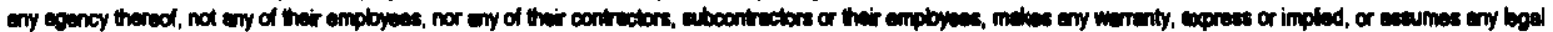

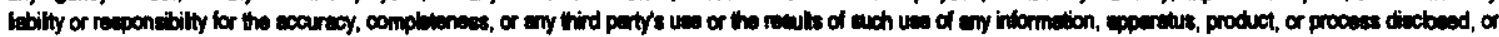

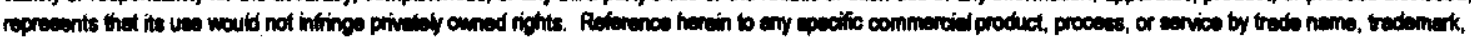

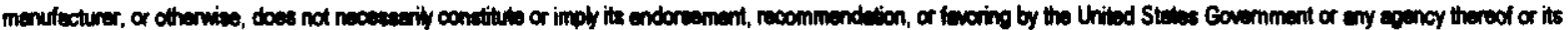

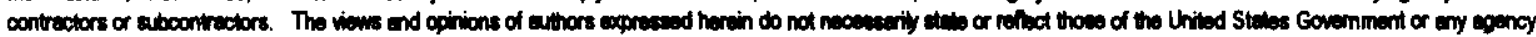
thereof. This report has been reproduced from the bect andeble copy. Printed in the United Stibse of Ammice. 


\section{CONTENTS}

1.0 INTRODUCTION 1

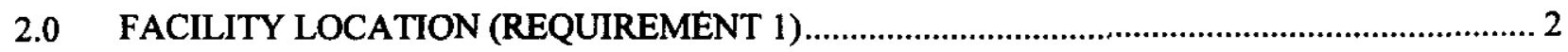

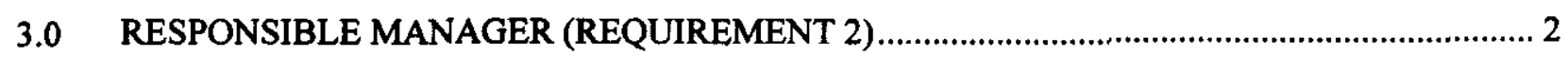

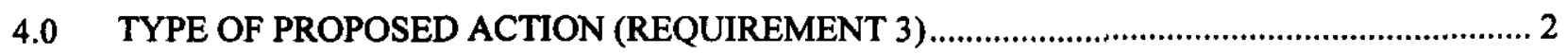

5.0 STATE ENVIRONMENTAL POLICY ACT (REQUIREMENT 4) ….................................... 3

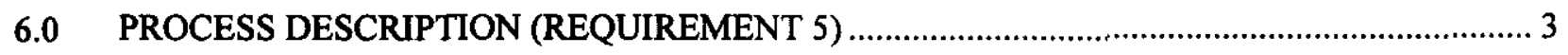

7.0 ANNUAL POSSESSION QUANTITY AND PHYSICAL FORM

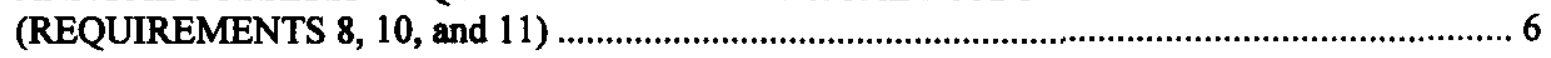

8.0 ABATEMENT TECHNOLOGY AND CONCEPTUAL DRAWING(S)

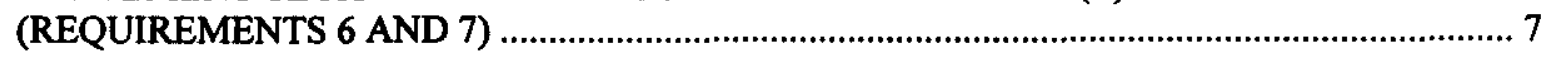

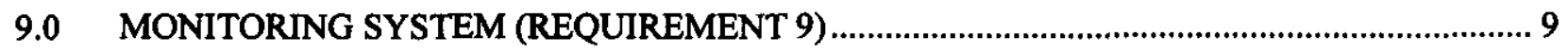

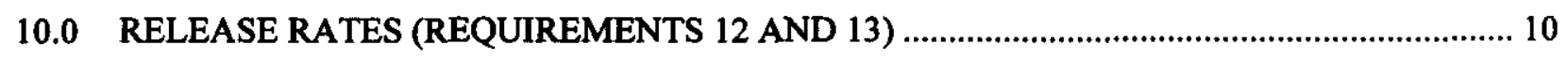

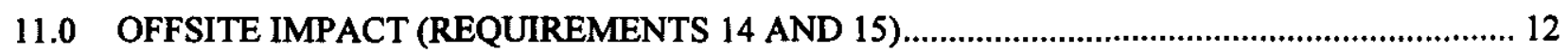

12.0 COST FACTORS AND FACILITY LIFETIME (REQUIREMENTS 16 AND 17) .................... 12

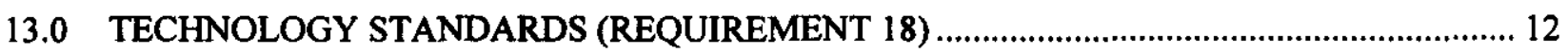

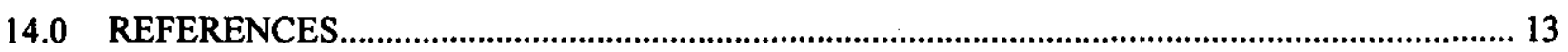

\section{ATTACHMENTS}

A INSTRUCTIONS FOR BOREHOLE SAMPLING (WHC-SD-EN-AP-181, REV. 0) ...........ATT A-i

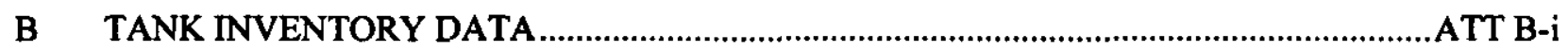

C TANK ISOTOPE TO CESIUM-137 RATIOS................................................................. C C-i

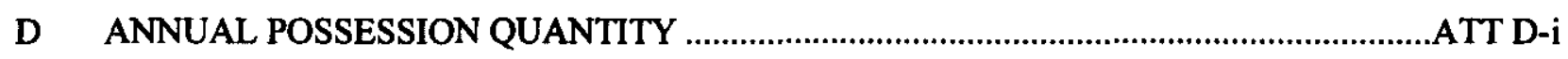

E POTENTIAL-TO-EMIT ASSUMPTIONS AND CALCULATIONS DRILLING BOREHOLES ......................................................................................... ETT E-i

F TWRS ALARACT DEMONSTRATION FOR SOIL EXCAVATION (USING

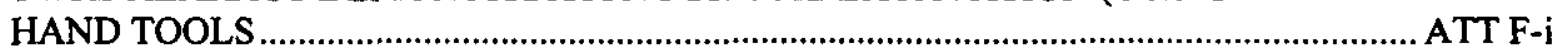

G SOIL CONTAMINATION STANDARDS FOR PROTECTION FOR PERSONNEL ..........ATT G-i 


\section{ATTACHMENTS (cont)}

H ANNUAL POSSESSION QUANTITY AND POTENTIAL TO EMIT FOR EXCAVATION ACTIVITIES ATT H-i

I POTENTIAL-TO-EMIT ASSUMPTIONS AND CALCULATIONS CLOSING BOREHOLES AND REMOVING CASING. ATT I-i

J SUMMARY OF POTENTIAL-TO-EMIT ASSUMPTIONS DRILLING BOREHOLES/CLOSING BOREHOLES AND REMOVING CASING ATT J-i

K POTENTIAL-TO-EMIT EXAMPLE CALCULATION ATT K-i

L TWRS ALARACT DEMONSTRATION FOR PACKAGING AND TRANSPORTATION OF EQUIPMENT AND VEHICLES

M DISCUSSION OF BEST AVAILABLE RADIONUCLIDE CONTROL TECHNOLOGY ATT M-i

N CAP88PC RUN DATA AND INFORMATION ATT N-i

\section{FIGURE}

Figure 1. Process Flow Diagram 15

Figure 2. Flow Diagram for Handling Perched Water and Purgewater. 16

Figure 3. Air Hammer Ventilation System.

\section{TABLES}

Table 1. Facility Locations.

2

Table 2. Average Allowable Concentrations of Cs-137. 


\section{NOTICE OF CONSTRUCTION FOR TANK WASTE REMEDIATION SYSTEM VADOSE ZONE CHARACTERIZATION}

\subsection{INTRODUCTION}

The following description and any attachments and references are provided to the Washington State Department of Health (WDOH), Division of Radiation Protection, Air Emissions \& Defense Waste Section as a notice of construction (NOC) in accordance with Washington Administrative Code (WAC) 246-247, Radiation Protection - Air Emissions. The WAC 246-247-060, "Applications, registration, and licensing", states "This section describes the information requirements for approval to construct, modify, and operate an emission unit. Any NOC requires the submittal of information listed in Appendix A." Appendix A (WAC 246-247-110) lists the requirements that must be addressed. The original NOC was submitted in May of 1999 as DOE/RL-99-34.

Additionally, the following description, attachments and references are provided to the U.S. Environmental Protection Agency (EPA) as an NOC, in accordance with Title 40 Code of Federal Regulations (CFR), Part 61, "National Emission Standards for Hazardous Air Pollutants." The information required for submittal to the EPA is specified in 40 CFR 61.07. The potential emissions from this activity are estimated to provide less than 0.1 millirem/year total effective dose equivalent (TEDE) to the hypothetical offsite maximally exposed individual (MEI), and commencement is needed within a short time frame. Therefore, this application is also intended to provide notification of the anticipated date of initial startup in accordance with the requirement listed in 40 CFR 61.09(a)(1), and it is requested that approval of this application will also constitute EPA acceptance of this initial start-up notification. Written notification of the actual date of initial startup, in accordance with the requirement listed in 40 CFR 61.09(a)(2) will be provided at a later date.

This NOC covers the activities associated with vadose zone characterization within the Single-Shell Tank Farms located in the 200-East and 200-West Areas of the Hanford Site. Vadose zone characterization activities include the drilling and sampling of soil from the surface to the depth of groundwater.

Boreholes that are drilled to groundwater will be extended into the aquifer a sufficient distance to enable a groundwater sample to be collected. Under extenuating circumstances it may be prudent to complete these characterization boreholes as groundwater monitoring wells.

For the various characterization options covered under this NOC, the maximum TEDE to the hypothetical MEI is 7.03 E-02 millirem per year. Based on using CAP88PC, Version 2, the MEI for Hanford Site public access is 5.7E-02 millirem per year (Energy Northwest) for the various characterization options. The maximum TEDE to the hypothetical MEI associated with site preparation (excavation) activities is $8.51 \mathrm{E}-03$ millirem per year. Based on using CAP88PC, Version 2, the MEI for Hanford Site public access is 4.2E-03 millirem per year (Energy Northwest) for the site preparation (excavation) activities. 


\subsection{FACILITY LOCATION (REQUIREMENT 1)}

U. S. Department of Energy, Office of River Protection

P.O. Box 550

Richland, Washington 99352-3562

Vadose zone characterization work may be performed in any of the single-shell tank farms. The following is a listing of coordinates for the individual single-shell tank farms based on the location of a tank within the farm (center location if data were readily available) or an average of two tank coordinates that would result in a location near the center of the farm.

Table 1. Facility Locations.

\begin{tabular}{|l|l|l|l|}
\hline \multicolumn{1}{|c|}{ Tank Farm } & \multicolumn{1}{|c|}{ Latitude } & \multicolumn{1}{|c|}{ Longitude } & \multicolumn{1}{c|}{ Reference Tank(s) } \\
\hline $241-\mathrm{A}$ & $46^{\circ} 33^{\prime} 11.6^{\prime \prime} \mathrm{N}$ & $119^{\circ} 31^{\prime} 2.3^{\prime \prime} \mathrm{W}$ & Average 241-A-103 \& -104 \\
$241-\mathrm{AX}$ & $46^{\circ} 33^{\prime} 15.7^{\prime \prime} \mathrm{N}$ & $119^{\circ} 31^{\prime} 29.6^{\prime \prime} \mathrm{W}$ & Average 241-AX-101 \& -104 \\
$241-\mathrm{B}$ & $46^{\circ} 33^{\prime} 52.3^{\prime \prime} \mathrm{N}$ & $119^{\circ} 32^{\prime} 13.9^{\prime \prime} \mathrm{W}$ & 241-B-108 \\
$241-\mathrm{BX}$ & $46^{\circ} 33^{\prime} 54.0^{\prime \prime} \mathrm{N}$ & $119^{\circ} 32^{\prime} 23.2^{\prime \prime} \mathrm{W}$ & Average 241-BX-101 \& -112 \\
$241-\mathrm{BY}$ & $46^{\circ} 33^{\prime} 58.5^{\prime \prime} \mathrm{N}$ & $119^{\circ} 32^{\prime} 36.1^{\prime \prime} \mathrm{W}$ & Average 241-BY-101 \& -112 \\
$241-\mathrm{C}$ & $46^{\circ} 33^{\prime} 28.2^{\prime \prime} \mathrm{N}$ & $119^{\circ} 31^{\prime} 12.0^{\prime \prime} \mathrm{W}$ & $241-\mathrm{C}-108$ \\
$241-\mathrm{S}$ & $46^{\circ} 32^{\prime} 22.9^{\prime \prime} \mathrm{N}$ & $119^{\circ} 37^{\prime} 88.8^{\prime \prime} \mathrm{W}$ & Average 241-S-101 \& -112 \\
$241-\mathrm{SX}$ & $46^{\circ} 32^{\prime} 13.7^{\prime \prime} \mathrm{N}$ & $119^{\circ} 37^{\prime} 43.0^{\prime \prime} \mathrm{W}$ & $241-\mathrm{SX}-113$ \\
$241-\mathrm{T}$ & $46^{\circ} 33^{\prime} 35.7^{\prime \prime} \mathrm{N}$ & $119^{\circ} 37^{\prime} 43.1^{\prime \prime} \mathrm{W}$ & $241-\mathrm{T}-108$ \\
$241-\mathrm{TX}$ & $46^{\circ} 33^{\prime} 20.0^{\prime \prime} \mathrm{N}$ & $119^{\circ} 37^{\prime} 44.9^{\prime \prime} \mathrm{W}$ & $241-\mathrm{TX}-110$ \\
$241-\mathrm{TY}$ & $46^{\circ} 33^{\prime} 26.4^{\prime \prime} \mathrm{N}$ & $119^{\circ} 37^{\prime} 45.6^{\prime \prime} \mathrm{W}$ & Average 241-TY-101 \& -106 \\
$241-\mathrm{U}$ & $46^{\circ} 32^{\prime} 41.9^{\prime \prime} \mathrm{N}$ & $119^{\circ} 37^{\prime} 43.7^{\prime \prime} \mathrm{W}$ & $241-\mathrm{U}-108$ \\
\hline
\end{tabular}

\subsection{RESPONSIBLE MANAGER (REQUIREMENT 2)}

The responsible manager for the activities described under this NOC is as follows:

Mr. R. T. French, Manager

U.S. Department of Energy, Office of River Protection

P.O. Box 550

Richland, Washington 99352

(509) 376-6677

\subsection{TYPE OF PROPOSED ACTION (REQUIREMENT 3)}

The proposed action results in the construction of new minor emission units. These will not represent significant modifications. 


\subsection{STATE ENVIRONMENTAL POLICY ACT (REQUIREMENT 4)}

The proposed action is categorically exempt from the requirements of the State Environmental Policy Act under WAC 197-11-845.

\subsection{PROCESS DESCRIPTION (REQUIREMENT 5)}

To accomplish the goals of the vadose zone characterization program, there will be a need to perform subsurface sampling within selected single-shell tank farms identified in Table 1. Subsurface sampling and drilling techniques will be performed using the guidance document contained in Attachment $\mathbf{A}$.

Up to ten equivalent boreholes may be drilled per year (consecutive 12-month period) by the methods described in this section of the NOC. An equivalent borehole for the purposes of this NOC is assumed to have a nominal top diameter of 10 inches for the first 50 feet and a nominal bottom diameter of 8 inches for the remaining 200 feet of pipe (average depth is 250 feet). Additionally, an equivalent borehole is assumed to contain a contaminated layer 20 feet long in the 10 -inch portion of the equivalent borehole. Each of the proposed subsurface sampling and drilling methods has the potential to emit radionuclides into the air. Individual methods are to be selected based on the likely level (concentration) of contaminants to be encountered. The highest levels of contamination occur closest to the tanks; however, as the depth below the tank increases, the levels of contamination decrease substantially. A conservative drilling approach (low potential to emit) will be applied. Borehole logging will be used to determine when it is appropriate to apply drilling techniques that may have a higher potential to emit. Zones not sampled during advancement of the borehole due to having a high potential to exceed exposure guidelines may be sampled by various side-wall sampling techniques as the boreholes are decommissioned.

The most aggressive (greatest potential for particulate generation) option for drilling equivalent boreholes will involve the use of an air rotary type drill. The air rotary type drill is expected to suspend particulate matter into the cyclone and the toriti (process equipment for material recovery) shown in Figure 1. According to the manufacturer, the torit has an efficiency of $99.96 \%$ for particulates with a median diameter of 0.4 microns. No abatement credit is taken for the cyclone or torit.

Samples taken during air rotary type drilling will be obtained from the "sampling sock" located on the side of the cyclone and/or from the drums underneath the cyclone and torit (see, Figure 1). The "sampling sock" is a polyethylene (or similar air tight material) bag that will catch material for geological, chemical and radiochemical analyses. Additional geological description samples may be obtained from the drums. The drums will be labeled to allow correlating the material level in the drum to the depth in the borehole where the material resided. The material in the drums may be sampled by pulling a mini-core from the drum. Sampling and change-out of the drums will be performed inside the containment structure with continuous HPT coverage. The radioactive material in the drums is expected to be at a very low level as assured by the administrative limits in Section 7.0 for use of the air rotary type drilling method.

Other possible borehole drilling techniques that may be used are briefly described below.

- Sonic drilling - a non-air assisted drill and drive system that mechanically removes the cuttings in a vibrated core barrel set up. The core barrel is vibrated down. This captures the soils in the barrel, the

\footnotetext{
${ }^{1}$ Torit is a registered trademark of Donaldson Company, Inc. - Minneapolis, MN
} 
barrel is removed and extruded, the casing is advanced by vibration and the whole process is repeated.

- Closed end probe - a casing with closed end is driven into the ground by any of a number of methodspile driver (percussion), vibrated (sonic), or air hammer (driven from inside of the pipe by an air driven hammer, the circulation air is not in direct contact with the soil and is not expected to be contaminated). At selected depths, the end of the probe is removed (straight pull, unscrewed or milled-drilled out) and a separate sampling probe inserted to catch the sample. Sampling is accomplished by advancing the sampling probe using one of the methods described above. In the event that samples cannot be obtained ahead of the driven casing, the casing is driven to its maximum depth and sampling is accomplished during decommissioning using a sampler driven into the sidewall of the borehole- Several telescoped lengths of probe may be used to achieve total depth for this method.

- Traditional cable tool drilling from top to bottom. A core barrel is driven into the soil by mechanical impact, the barrel is removed, emptied and the casing is driven down by impact at surface. When the barrel is removed from the ground, the barrel is sleeved into plastic and the bottom is tied off. The barrel is then placed into the drum, the exterior of the barrel is hit with a hammer or other hard object to dislodge the soil into the plastic sleeving. The plastic sleeving is removed from the barrel, tied off at the top and placed into the drum. The soil samples from this activity will be contained in the plastic sleeving. A sub-sample may be collected from the sleeved material for submission to the laboratory.

- Cone Penetrometer - consists of a probe containing either instrumentation to measure activity in the ground, or a soil sampler both of which is pushed into the ground by sheer weight. There is minimal potential for sudden or other air emissions from this technology. The equipment design and operation keeps personnel and environmental exposures to contamination very low (i.e., no drill tailings, no compressed air, pipe is pushed slowly, sensors provide real-time information, soil exposure to the air pathway is extremely minimal).

- GeoProbe - consists of a small, truck-mounted sampling device which is pushed into the ground while the small diameter push rod is vibrated. Like the cone penetrometer, no materials are returned to the surface during advancement. Upon reaching sample depth, a messenger is sent down the hollow drill rod and the sample tool tip is retrieved to the surface. The tool is then advanced and the sample is collected.

- Auger Drilling - Consists of a hollow stem with flights of helical twist lifting surfaces which are rotated into the ground. Soil is displaced upward by the lifting surfaces and accumulates at the ground surface. The drill cuttings are then transferred by hand tools into containers. Samples are collected by lowering a split-spoon sampler through the hollow stem of the auger flights and driving it into the underlying undisturbed material.

Other soil sampling techniques will include one or a combination of the following techniques:

- Air Rotary Split Spoon

- Drive Split Spoon Sampler

- Cable Tool

- Cable Tool and Auger with a Split Spoon Core Barrel

- Sonic Core Barrel and Split Spoon

- Rotary Coring

- Sidewall Sampling. 
With the exception of sidewall sampling, a detailed description of the drilling and sampling techniques are discussed in chapter two of EPA 1993. Sidewall sampling of the borehole may involve the use of a "whipstock" located at the end of the casing to deflect a sample tube from the vertical direction and direct it into the surrounding formation (maximum of 8 inches). Once the sample is captured, the drill rod with the sampler attached will be removed from the borehole using the drilling machine. At the surface, the sampler will be bagged or sleeved into plastic or other suitable container (e.g., shielded container) after retrieval and packaged in a container suitable for shipment to the laboratory for analysis. Other sidewall sampling techniques may involve a lever-action sampler (the sampler is driven into the formation through a cantilever action) or a rotating formation "shaving" device with the sample captured in an under-slung basket.

For casing removal, if decontamination or application of fixatives cannot reduce smearable contamination to less than $100,000 \mathrm{dpm}$ per $100 \mathrm{~cm}^{2}$ for beta/gamma or $2,000 \mathrm{dpm}$ per $100 \mathrm{~cm}^{2}$ for alpha, the casing shall be pulled into plastic sleeving. The casing shall be unthreaded if possible, or cut using a wheel cutter or by disconnecting from other segments into a nominal length of 10 feet. The wheel cutter shall not use a high speed blade. When necessary, either to accomplish casing removal for borehole decommissioning or to enable pull-back for sidewall sampling, the casing will be cut at depth using a Bowen Casing Cutter (or equivalent). This device is mechanically deployed against the casing and then rotated to deploy the cutting knives. Water may be used to cool the cutter blades. If decontamination or application of fixatives cannot reduce smearable contamination to less than $100,000 \mathrm{dpm}$ per $100 \mathrm{~cm}^{2}$ for beta/gamma or $2,000 \mathrm{dpm}$ per $100 \mathrm{~cm}^{2}$ for alpha and the casing is sleeved in plastic, no more than one foot of casing shall be exposed to air during the cutting process. Cuttings shall be captured in a draped plastic. If decontamination or application of fixatives cannot reduce smearable contamination to less than $100,000 \mathrm{dpm}$ per $100 \mathrm{~cm}^{2}$ for beta/gamma or $2,000 \mathrm{dpm}$ per $100 \mathrm{~cm}^{2}$ for alpha, the pieces cut shall be capped with plastic or the sleeving will be horsetailed and the sections shall be placed in a burial box. Using a tremie, the hole will be backfilled with clean (non-radioactive) materials (e.g., granular bentonite and/or grout). A tremie is an apparatus that consists of a hopper or funnel at the top (ground level) end and a long metal tube for placing fill materials directly on the bottom of the borehole. Using a tremie reduces void spaces while backfilling the hole and reduces the potential to resuspend contaminated particulates. Casing removal activities will be performed outside of the containment structure. The closure of the equivalent boreholes may also be performed by backfilling the borehole using a tremie without pulling the casing.

During drilling activities, there is the possibility of hitting perched water. Perched water is groundwater separated from an underlying body of groundwater by unsaturated rock. Any perched water would be collected in the drum at the bottom of the cyclone. The perched water is not expected to consist of undiluted tank waste since gamma logging activities have noted that the gamma sources from tank waste decrease with depth that is above any perched water table (BNWL 1966).

Approximately 1,000 gallons of purgewater will be removed from each equivalent borehole prior to inserting a screen below the water table. After installation of the screen, groundwater samples will be taken. An average of 2,000 gallons of water (includes perched water, purgewater and groundwater sampling) is expected to be removed from each equivalent borehole. As shown in Figure 2, perched water and purgewater will be collected in passively ventilated open top containers. When a sufficient volume of water has been collected or at the end of groundwater sampling activities, the water will be transferred from the passively ventilated containers into a tanker truck for treatment at the 200 Area ETF or other permitted storage/treatment facility. Water may be transferred directly from the borehole to the tanker truck, bypassing the intermediate containers. 
Approximately 3,500 cubic feet of soil may need to be excavated per year. Soil excavation may be required to anchor and guide the drill, and to ensure that drilling activities will miss buried equipment and utilities. Excavation will be performed using manual methods, backhoe, and/or the guzzler.

\subsection{ANNUAL POSSESSION QUANTITY AND PHYSICAL FORM (REQUIREMENTS 8, 10, AND 11)}

The annual possession quantity (APQ) was estimated based on drilling and closing ten equivalent boreholes per year with the soil containing an average of 330 microcuries of Cs-137 per gram of soil. The 330 microcuries of Cs-137 per gram of soil is based on a 100 percent saturation of the soil pore space (30 percent total porosity) by a waste solution (BNWL 1966). [Based on previous soil characterization activities, the highest actual measured Cs- 137 concentration in the soil was 100 microcuries (100,000 nanocuries) per gram of soil (BNWL 1966).]

Other isotopes may have higher off-site dose consequences and they have been accounted for; however, Cs- 137 was selected as the base isotope because it can be readily detected in the soil. Attachment B provides a listing of known or assumed leaking tanks (HNF 1998) and the corresponding tank inventory from the database in the Tank Waste Information Network System 2 which is available on the internet (http://twins.pnl.gov:8001). A ratio of each isotope to Cs-137, based on curies, was calculated for each tank as shown in Attachment $C$. A comparison of the curie ratio for each isotope in each tank was performed with the average value being considered representative of the extent of soil contamination for other isotopes.

As shown in Attachment $\mathrm{D}$, a maximum of 10 equivalent boreholes may be drilled per year. Each equivalent borehole will have a nominal top diameter of 10 inches for the first 50 feet and a nominal bottom diameter of 8 inches for the remaining 200 feet of boring (average depth is 250 feet). As a result of drilling, the soil has been observed to expand approximately $15 \%$ over what would be calculated based strictly on the volume of the equivalent borehole as the soil is no longer compacted. Based on previous drilling experience, the vertical range of soil contamination is assumed to span an average of 20 feet per equivalent borehole (HNF 1999a). For conservatism, all contamination is assumed to occur in the 10inch diameter section of the equivalent borehole.

Based on the previous assumptions, approximately 112 cubic feet of soil is removed per equivalent borehole. An estimated 13 cubic feet of the soil per equivalent borehole is assumed contaminated. Using the average isotope ratios multiplied by 330 microcuries of Cs- 137 (average) per gram of soil and the total weight of soil [based on an average density of 97.5 pounds per cubic foot for loose dry sand and gravel, (Avallone and Baumeister)] the APQ of each isotope for drilling has been calculated and is provided in Attachment D.

The APQ associated with the closure of 10 equivalent boreholes has also been provided in Attachment D. Under field conditions, the soil column abrasively scrubs the outside of the casing free of a soil layer leaving a few patches (up to $15 \%$ of the exposed surface area) of soil on the casing material (DSI 99b). The thin soil patches were assumed to consist of a thickness of 1/64-inch with the worst case composition of 330 microcuries of Cs-137 per gram of soil. For conservatism an additional $10 \%$ was added to the exterior contamination on the casing to account for any potential contamination on the interior of the casing. For boreholes that do not require casing removal, the APQ is assumed to be zero since the APQ was included in constructing the borehole. 
A summary of the total APQ associated with the installation and closure of 10 equivalent boreholes per year has been provided in Attachment D (4.38E+04 curies per year). All isotopes are assumed to be in the form of particulate solids or liquids.

A downhole air hammer may be used to drive a sampler while using a closed end probe. Although the circulation air is not expected to be in contact with contaminated soil, the potential exists for a small amount of residual soil being deposited on the inside walls of the casing during removal of the drive tip to allow for sampling ahead of the advancing casing. For conservatism, as shown in Attachment E, the APQ associated with using the Air Hammer was assumed to be 0.05 cubic feet of soil per equivalent borehole with a contamination level corresponding to $3.30 \mathrm{E}-04$ curies of $\mathrm{Cs}-137$ per gram of soil (195 curies per year).

The APQ associated with perched water, purgewater and groundwater sampling is based on drilling 10 equivalent boreholes per year, with an average of 2,000 gallons per borehole contaminated with Tc-99 at a concentration of 48,000 picocuries per liter. The 48,000 picocuries per liter of Tc-99 corresponds to groundwater sampling near 241-SX Tank Farm and it represents the highest concentration that has been found in groundwater (PNNL-12086). For conservatism, a value of 100,000 picocuries per liter was used in calculating the APQ. As shown in Attachment E, the APQ associated with perched water, purgewater and groundwater sampling is estimated at 7.57E-03 curies.

The APQ associated with excavation activities is based on excavating 3,500 cubic feet of soil contaminated with $\mathrm{Sr}-90$ to produce a count rate of 1,000 disintegrations per minute (dpm) per probe area and Am-241 to produce a count rate of $140 \mathrm{dpm}$ per probe area. The suggested count rates are consistent with the maximum allowable count rate base on the "TWRS ALARACT Demonstration For Soil Excavation Using Handtools" (Attachment F) and the Categorical NOC for the Guzzler on the Hanford Site. The conversion factors for converting dpm to curies is provided in Attachment G. As shown in Attachment $\mathrm{H}$, the APQ associated with excavation using handtools, backhoe or Guzzler is 74.9 curies.

\subsection{ABATEMENT TECHNOLOGY AND CONCEPTUAL DRAWING(S) (REQUIREMENTS 6 AND 7)}

Emissions from any air rotary drilling activities will be contained using an active ventilation system attached to the process equipment and a passive vent system attached to the process equipment containment structure. The active ventilation system will have radioactive air emissions abated by one stage of high efficiency particulate air (HEPA) filter. The HEPA filter located downstream of the will be tested to provide a minimum collection efficiency of 99.95 percent for particulates with a median diameter of 0.3 microns. The containment structure will have a passive HEPA type filter that will provide high efficiency collection.

The average volumetric flowrate from the compressor to the equivalent borehole is estimated to be 1.2 cubic meters per second $(2,400$ cubic feet per minute) with approximately 0.6 cubic meters per second ( 1,200 cubic feet per minute) returning out the borehole into the cyclone. The difference in the flowrate is attributed to the soil column absorbing a fraction of the air volume which is gradually released into the process and abatement control equipment after the compressor is turned off.

The exhaust fan will have a maximum average velocity of 0.85 cubic meters per second $(1,800$ cubic feet per minute) with a range of 0.6 to 1.2 cubic meters per second (1,200 to 2,400 cubic feet per minute) to maintain the ducting between the cyclone and the HEPA filter at atmospheric or less than atmospheric pressure. The drill rig will be sealed to the casing so that particulates will be contained and routed to the process equipment (e.g., cyclone and torit) located inside the plastic containment structure. The flange on 
the well discharge head and on the inlet of the cyclone will be double flanged to reduce the potential for an unabated release to the atmosphere. Additionally, the flexible line connecting the well discharge head and the cyclone will be encased by another flexible line. The flexible encasement line and flanges will also be vented to the cyclone. The plastic containment structure surrounding the process control equipment will be fitted with one stage of HEPA type filtration. Figure 1 is a conceptual drawing of the proposed system.

When the borehole has been completed and the process equipment is ready to be removed, equipment will be broken down at the disconnect points and contaminated equipment openings will be sealed or plugged to minimize the spread of contamination. All work related to disconnecting and moving the equipment will be performed in accordance with TWRS as low as reasonably achievable control technology (ALARACT) demonstration number 12 (HNF-1999b), "TWRS ALARACT Demonstration for Packaging and Transportation of Equipment \& Vehicles" (Attachment L).

Emission controls to be used during sonic drilling, cable tool drilling, cone penetrometer, use of the closed end probe, and casing removal will be decontamination by non-aggressive manual methods such as wiping, sleeving into plastic or having fixatives applied to prevent the spread of contamination if the smearable contamination levels are greater than 100,000 disintegrations per minute per 100 square centimeters for beta/gamma or 2,000 disintegrations per minute per 100 square centimeters for alpha.

During cable tool drilling, when the barrel is removed from the ground, the barrel will be sleeved into plastic and the bottom will be tied off. During sample removal, the exterior of the barrel is hit with a hammer or other hard object, the moist soil will dislodge into the plastic sleeving with minimal potential for emissions. The soil samples from this activity will remain in plastic sleeving after the sample is removed from the barrel. In the event that the soil does not dislodge from the barrel, the entire barrel will remain in the sleeving and the barrel will be placed in a suitable closed container for shipment to the laboratory or placed in a closed burial box.

Additionally, other sample containers may be wrapped in plastic after retrieval and the casing may be sleeved into plastic during the removal process to prevent the spread of contamination.

As shown in Figure 3, emissions associated with the downhole air hammer will be routed to a HEPA filter that may or may not have an exhaust fan associated with it. In the event that an exhaust fan is used to reduce the velocity head on the HEPA filter, an exhauster no larger than 0.95 cubic meters per second (2,000 cubic feet per minute) will be attached to the HEPA filter. The drill rig will be sealed to the casing so that any particulates in the borehole casing will be contained and routed to the emission unit.

Emissions associated with perched water, purgewater and groundwater samples are expected to be close to nondetectable. In the event that perched water is encountered, actual emissions from drilling will decrease due to contaminated soil becoming wet and less mobile. Purgewater results from pumping and all water is contained in the discharge piping, thus no releases to the air will occur. As a result, potential emissions associated with radionuclides inside the casing will actually decrease since the radionuclides will be wetted or in solution. As shown in Figure 2, no controls are proposed for perched water, purgewater and groundwater sampling activities since water retards resuspension of particulate radionuclides.

Excavation activities using handtools will be performed in accordance with "Demonstration For Soil Excavation Using Handtools" (Attachment $\mathrm{H}$ ). Excavation with a backhoe will be done using the equivalent controls identified in Attachment $F$. Use of the guzzler will be done in accordance the Categorical NOC of use of the Guzzler on the Hanford Site. 
A sustained wind speed restriction of 20 miles per hour will be applied to drilling, sampling, casing removal work, and excavation activities. This criterion applies to sustained wind speeds as determined by the Hanford Meteorological Station. The radiological conditions associated with the work activities will be controlled by following a radiation work package (RWP). Continuous Health Physics Technician coverage will be provided while drilling, sampling and removing casing.

\subsection{MONITORING SYSTEM (REQUIREMENT 9)}

Periodic confirmatory monitoring of emissions from borehole drilling using the air rotary drilling technique will be accomplished by a destructive or non-destructive analysis of the record filter combined with radiological field surveys during the work. The record filter, located downstream of the active ventilation HEPA filter, will receive all flow from the first filter and will have a minimum efficiency of 90 percent for particulates with a median diameter of 0.3 microns as specified by the manufacturer. The radiological analyses from the soil samples will be averaged to determine the isotopic distribution of Strontium-90 (Sr-90), Cs-137, Plutonium-239 (Pu-239) and Americium (Am-241). Sr-90, Pu-239 and $\mathrm{Am}-241$ are the isotopes estimated to potentially contribute greater than $10 \%$ of the unabated offsite dose; whereas, $\mathrm{Pu}-239$ and $\mathrm{Sr}-90$ are the isotopes estimated to contribute greater than $25 \%$ of the offsite dose due to abated emissions. The record filter will be counted using a gamma spectrometer calibrated to Cs-137. Counting will be done annually using either a destructive or non-destructive technique.

The soil sample isotope ratios discussed above will be applied to Cs-137 on the record filter to confirm low emissions instead of the ratios used in Attachment C. The actual soil sample isotopic ratios are expected to be less than the overly conservative ratios contained within Attachment $\mathrm{C}$ since Pu-239 and Am-241 are not as soluble and will not transport through the entire leak plume as readily as Cs-137. The proposed periodic confirmatory method is capable of providing the required detection levels to verify low emissions. In addition, the HEPA filter housing will be field surveyed after the completion of each borehole to verify low emissions.

Periodic confirmatory monitoring of the passive HEPA type filter will be accomplished by performing a field survey of the filter housing to confirm low emissions. The field survey of the passive HEPA type filter will be performed after the completion of each borehole.

Fugitive emissions may result from cable tool and sonic drilling, use of the closed end probe and the cone penetrometer, the plastic containment structure during air rotary drilling, and during dismantlement/assembly or relocating the ventilation equipment, plastic containment structure, or process equipment. To confirm low emissions, periodic confirmatory monitoring will be accomplished by operating three fixed head samplers around the location of where the drilling and sampling operations are occurring. The fixed head samplers will be located within 100 feet of where the drilling and sampling work activities are occurring and will be operated whenever the work activities have the potential to emit radionuclides. During soil sampling activities that require the use of a downhole air hammer, one of the three fixed head samplers will be located near the air exhaust stream (exhaust fan or HEPA filter as appropriate). After packaging the equipment and samples for shipment, Health Physics Technicians will perform surveys (swipes for removable contamination) in accordance with TWRS as low as reasonably achievable control technology (ALARACT) demonstration number 12 (HNF-1999b), "TWRS ALARACT Demonstration for Packaging and Transportation of Equipment \& Vehicles" (Attachment L).

Fugitive emissions may also result from excavation, removing casing from the ground and from transferring the perched water and purgewater. To confirm low emissions, periodic confirmatory monitoring will be accomplished by operating three fixed head samplers around the location of the work activities. The fixed head samplers will also be located with 100 feet of where the casing removal 
activities are occurring and will be operated when the work activities have the potential to emit radionuclides.

In addition to the fixed head samplers, monitoring during excavation activities using handtools will be performed in accordance with "Demonstration For Soil Excavation Using Handtools" (Attachment F). Monitoring during excavation with a backhoe will be done using the equivalent monitoring requirements identified in Attachment F. Use of the guzzler will be done in accordance the Categorical NOC of use of the Guzzler on the Hanford Site.

\subsection{RELEASE RATES (REQUIREMENTS 12 AND 13)}

Up to ten equivalent boreholes may be drilled by the methods previously described in the NOC. Each of the proposed methods has the potential to emit radionuclides into the air. Individual methods are to be selected based on the highest concentration of contaminants likely to be encountered. The highest levels of contamination occur closest to the tanks. As the depth below the tank increases, the levels of contamination decrease substantially. Of the methods considered for use, a conservative drilling approach (low potential to emit) will be applied. Borehole logging will be used to determine when it is appropriate to apply drilling techniques that may have a higher potential to emit. Zones not sampled during advancement of the borehole due to having a high potential to exceed occupational exposure guidelines, may be sampled by various side-wall sampling techniques as the boreholes are decommissioned.

Based on the methods of drilling and the total APQ discussed in Section 7.0, handling limits were calculated for each of the available drilling methods to ensure that the estimated TEDE to the hypothetical $\mathrm{MEI}$ remains less than 0.08 millirem per 12 month consecutive period. Drilling method selection and subsequent monitoring of excavated material will define the number of boreholes that may be drilled in any year. The estimated emissions associated with the different drilling techniques are located in Appendix E. The assumptions used to estimate the emissions associated with the various drilling techniques and the administrative limits are discussed below.

Air Rotary - The administrative average handling limit is 5.0 nanocuries of cesium-137 (Cs-137) per gram of soil which results in a total handling limit of $2.8 \mathrm{E}-02$ curies of Cs-137 per year. The administrative limit is based on previous drilling experience where the average vertical range of soil contamination is assumed to span an average of 20 feet per equivalent borehole (HNF 1999a). Using the average isotope ratios multiplied by the administrative average limit of 5.0 nanocuries of Cs-137 per gram of soil and the total weight of soil [based on an average density of 97.5 pounds per cubic foot for loose dry sand and gravel (Avallone and Baumeister)], the total annual handling limit and estimated emission for each isotope has been provided in Attachment $E$.

Cable Tool and Sonic Drilling - The administrative average handling limit is 5.0 microcuries of Cs-137 per gram of soil (total combined handling limit of 28 curies of Cs-137 per year). The total annual handling limit for the cable tool and sonic drilling were calculated similar to that for air drilling since all the material will be removed from the equivalent borehole and brought to the surface. Using the average isotope ratios multiplied by the administrative average limit of 5.0 microcuries of Cs-137 per gram of soil and the total weight of soil [based on an average density of 97.5 pounds per cubic foot for loose dry sand and gravel (Avallone and Baumeister)], the total annual handling limit for each isotope has been provided in the Attachment $E$.

Closed End Probe and Cone Penetrometer - The administrative handling limit was conservatively estimated based on the soil containing an average of 330 microcuries of Cs-137 per gram of soil (total 
combined annual handling limit of 71.8 curies of Cs-137 per year). The 330 microcuries of Cs- 137 per gram of soil is based on a 100 percent saturation of the soil pore space ( 30 percent total porosity) by a waste solution (BNWL 1966). The annual handling limit for the closed end probe and the cone penetrometer is based on the contaminated soil volume brought to the surface which occurs during sampling. These emissions are contained within Attachment $E$ and assume the equivalent of 10, 4-inch diameter by 2 feet long (approximately 1.75 cubic feet) samples, with $25 \%$ of the sample ( 0.44 cubic feet) being contaminated with the worst case composition of 330 microcuries of Cs- 137 per gram of soil.

Attachment I contains the estimated emissions associated with the closure of 10 equivalent boreholes. For boreholes that do not require casing removal, the emissions of radionuclides is assumed to be equal to zero since the radioactive material available for release was included in constructing the borehole.

Attachment $\mathrm{J}$ contains a summary of the emissions associated with the installation and closure of 10 equivalent boreholes per year using the air rotary method, the cable tool /sonic drilling, and the closed end probe/cone penetrometer. An example calculation has been provided in Attachment $\mathrm{K}$.

The average soil concentration used to derive the emissions estimates discussed above is based on the total amount of Cs-137 in the actual borehole divided by the estimated volume of contaminated soil in the equivalent borehole (calculated in Attachment E) for the selected method. In the event that fewer than ten equivalent boreholes are drilled, the average limit may be adjusted upwards to match the total annual possession quantity associated with each method. If the limit is reached in fewer than 10 boreholes, no more boreholes may be drilled until the 12 consecutive month period falls below the handling limit. Conversely, if the limit would not be reached after drilling 10 boreholes, additional boreholes may be drilled until the annual handling limit is reached. Table 2 has been included below to demonstrate how the average limit would be adjusted based on drilling one, five, and ten equivalent boreholes per year.

Table 2. Average Allowable Concentrations of Cs-137.

\begin{tabular}{|l|c|c|c|c|}
\hline & $\begin{array}{c}\text { Estimated Volume of } \\
\text { Contaminated Soil Per } \\
\text { Equivalent Borehole } \\
\text { (Appendix D) }\end{array}$ & $\begin{array}{l}\text { One Borehole Per } \\
\text { Year }\end{array}$ & $\begin{array}{l}\text { Two Boreholes } \\
\text { Per Year }\end{array}$ & $\begin{array}{c}\text { Ten Boreholes } \\
\text { Per Year }\end{array}$ \\
\hline $\begin{array}{l}\text { Air Rotary } \\
\text { Drilling }\end{array}$ & 12.54 cubic feet & $\begin{array}{l}5.0 \text { E-08 curies per } \\
\text { gram of soil }\end{array}$ & $\begin{array}{l}1.0 \text { E-08 curies } \\
\text { per gram of soil }\end{array}$ & $\begin{array}{l}5.0 \text { E-09 curies } \\
\text { per gram of soil }\end{array}$ \\
$\begin{array}{l}\text { Cable Tool or } \\
\text { Sonic Drilling }\end{array}$ & 12.54 cubic feet & $\begin{array}{l}5.0 \text { E-06 curies per } \\
\text { gram of soil }\end{array}$ & $\begin{array}{l}5.0 \text { E-06 curies } \\
\text { per gram of soil }\end{array}$ & $\begin{array}{l}5.0 \text { E-06 curies } \\
\text { per gram of soil }\end{array}$ \\
$\begin{array}{l}\text { Closed End Probe } \\
\text { or Cone } \\
\text { Penetrometer }\end{array}$ & 0.44 cubic feet & $\begin{array}{l}3.3 \text { E-03 curies per } \\
\text { gram of soil }\end{array}$ & $\begin{array}{l}\text { 6.6 E-04 curies } \\
\text { per gram of soil }\end{array}$ & $\begin{array}{l}3.3 \text { E-04 curies } \\
\text { per gram of soil }\end{array}$ \\
\hline
\end{tabular}

Downhole Air Hammer - As shown in Attachment E Emissions associated with the downhole air hammer are based on the using a release fraction of 1.0 for the air hammer APQ and a HEPA filter efficiency of $99.95 \%$ for particles with a median diameter of 0.3 microns.

Perched Water, Purgewater, and Groundwater Sampling - Emissions associated with perched water, purgewater and groundwater sampling are based on applying a 2.0 E-03 (two times the 40 CFR 61 Appendix D release fraction of $1.0 \mathrm{E}-03$ for liquids and particulates) release fraction to the annual possession quantity. The $2.0 \mathrm{E}-03$ release fraction was used to conservatively account for transferring the water into the temporary containment structure and the subsequent transfer to the tanker truck. The total volume of the groundwater samples is insignificant compared to the potential volume associated with perched water or purgewater; therefore, applying the 2.0 E-03 release fraction to the groundwater samples 
will not have a significant impact on the estimated emissions. A summary of emissions associated with perched water, purgewater and groundwater sampling is provided in Attachment E. Emissions associated with perched water, purgewater and groundwater sampling are insignificant when compared to emissions associated with drilling and casing removal activities.

Excavation Activities - Release rates associated with excavation activities have been provided in Attachment $\mathrm{H}$. A release fraction of $1 \mathrm{E}-03$ was used for excavation activities with handtools or a backhoe. A release fraction of 1.0 was used for the Guzzler.

\subsection{OFFSITE IMPACT (REQUIREMENTS 14 AND 15)}

A detailed summary of the estimated potential-to-emit TEDE to the hypothetical MEI for each radionuclide for the various drilling techniques, casing removal activities, perched water, purgewater, groundwater sampling, and overall total summary has been provided in Attachments D, E, H, and I. The MEI is 20,200 meters east southeast of the 200-East Area of the Hanford Site. As shown in Attachment $\mathrm{N}$, alternative MEI's on the Hanford Site and the associated CAP88PC (version 2) run have been provided.

\subsection{COST FACTORS AND FACILITY LIFETIME (REQUIREMENTS 16 AND 17)}

Requirement 16 is not applicable because a best available radionuclide control technology (BARCT) demonstration is provided (Attachment $\mathbf{M}$ ).

The maximum design life of the project is twenty years (July 15, 2019).

\subsection{TECHNOLOGY STANDARDS (REQUIREMENT 18)}

For air rotary drilling, the HEPA filter performance standards of ASME/ANSI N510, Section 10.5 will be met. The powered HEPA filter will have a minimum efficiency of 99.95 per cent for particles with a median diameter of 0.3 microns. ASME/ANSI AG-1 for the HEPA filter will be met as documented in a letter from the U.S. Department of Energy, Richland Operations Office, to the Washington State Department of Health (99-EAP-213). Other sections of ASME/ANSI 509 and 510 do not apply to this system due to its temporary configuration. The passive HEPA filter will be factory tested to a minimum efficiency of 99.95 per cent for particles with a median diameter of 0.3 microns and will provide a high efficiency of collection during passive ventilation. The systems will be visually inspected daily during operation and after any relocations to ensure the systems continue to operate as designed. Additionally, line pressure tests will be performed on the line between the well head and the cyclone and line between the torit and the fan prior to starting a new borehole. The line pressure test will be performed in accordance with ASME/ANSI N510.

In accordance with WAC 246-247-075(3), for emission units with a potential-to-emit of less than 0.1 millirem per year TEDE to the MEI, the option exists to estimate radionuclide emissions in accordance with 40 CFR 61 Appendix D, or other approved methods. Additionally, WDOH may require periodic confirmatory measurements during routine operations to verify low emissions. For the air rotary drilling, a destructive or nondestructive analysis of the record filters are proposed to be used for providing periodic confirmatory measurement to verify low emissions. Since the exhaust flow rate will not be 
needed to determine emissions, 40 CFR 60 Appendix A, Methods 1, 1A, 2, 2A, 2C, 2D, 4, 5, and 17 do not apply. In addition, ANSI N13.1 does not address the record filter system design because a sampling probe will not be used to measure emissions.

The air rotary drilling monitoring method will be compatible with NQA-1 as imposed by NESHAP Quality Assurance Project Plan for Radioactive Airborne Emissions, all of Sections 2.0, 3.0 and 5.0. ANSI/ASME NQA-2 is no longer an active National Standard and has been incorporated into NQA-1.

During sampling activities, when using an air hammer to drive the sampler, any possible emissions from the well head will be routed through a HEPA or HEPA type filter. The powered HEPA filter will have a minimum efficiency of 99.95 per cent for particles with a median diameter of 0.3 microns. ASME/ANSI AG-1 for the HEPA filter will be met as documented in a letter from the U.S. Department of Energy, Richland Operations Office, to the Washington State Department of Health (99-EAP-213). Other sections of ASME/ANSI 509 and 510 do not apply to this system due to its temporary configuration. The passive HEPA filter will be factory tested to a minimum efficiency of 99.95 per cent for particles with a median diameter of 0.3 microns and will provide a high efficiency of collection during passive ventilation. The systems will be visually inspected daily during operation and after any relocations to ensure the systems continue to operate as designed. Additionally, line pressure tests will be performed on the line between the well head and the filter and/or fan (if applicable) prior to starting a new borehole. The line pressure test will be performed in accordance with ASME/ANSI N510.

For cable tool drilling, sonic drilling, closed end probe, cone penetrometer, casing removal activities, purgewater, and groundwater sampling, the technology standards do not apply since these will be fugitive emission sources. Emissions will be maintained using BARCT (decontaminating, plastic sleeving and applying fixatives as needed) for contamination controls.

\subsection{REFERENCES}

BNWL, 1966, Characterization of Subsurface Contamination in the SX Tank Farm, BNWL-CC-701, by J. R. Raymond and E. G. Shdo, Battelle-Northwest, Richland, Washington.

DSI-99a, "Volume of fines Collected During Air Drilling", DSI, Kent Reynolds, Waste Management Northwest, Inc., to Stan Hill, Waste Management Federal Services of Hanford, Inc., Richland, Washington, January 15, 1999.

DSI-99b, "Well Decommissioning", DSI, Kent Reynolds, Waste Management Northwest, Inc., to Stan Hill, Waste Management Federal Services of Hanford, Inc., Richland, Washington, February 22, 1999.

DOE/RL-98-49, Tank Waste Remediation System Vadose Zone Program Plan, U.S. Department of Energy, Richland Operations Office, Richland, Washington.

DOE-RL, 1999, letter, 99-EAP-213, Mr. J. E. Rasmussen, U.S. Department of Energy, Richland Operations Office, to Mr. A. W. Conklin, Washington State Department of Health, “Technical Justification for a Temporary Deviation to American Society of Mechanical Engineers (ASME) AG-1, Section FC, 5100 High-Efficiency Particulate Air (HEPA) Filter Qualification Test Requirements", March 22, 1999.

DOE/RL-99-34, Notice of Construction for Tank Waste Remediation System Vadose Zone Characterization, U.S. Department of Energy, Richland Operations Office, Richland, Washington. 
EPA, 1993, Subsurface Characterization and Monitoring Techniques, Volume 1, EPA/625, R-93-003a, U.S. Environmental Protection Agency, Center for Environmental Research Information, Cincinnati, Ohio.

HNF, 1998, Waste Tank Summary Report for Month Ending July 31, 1998, HNF-EP-0182-124, Fluor Daniel Hanford, Inc., Richland, Washington.

HNF, 1999a, Radionuclide Inventories of Liquid Waste Sites at Hanford, HNF-1744, Fluor Daniel Hanford, Inc., Richland, Washington, expected release June 1999.

HNF 1999b, Control of Airborne Radioactive Emissions for Frequently Performed TWRS Work Activities (ALARACT Demonstrations), HNF-4327, Fluor Daniel Hanford, Inc., Richland, Washington, April 1999.

PNNL-12086, Hanford Site Groundwater Monitoring FY 1998, M.J. Hartman, et. al, Pacific Northwest National Laboratory, February 1999.

E. A. Avallone and T. Baumeister III, "Marks' Standard Handbook for Mechanical Engineers", $9^{\text {th }}$ Edition, McGraw Hill, 1987.

WDOH, 1992, Letter, Air 92-107, A. W. Conklin, Washington State Department of Health, to J. D. Bauer, U.S. Department of Energy, Richland Operations Office, no subject, October 5, 1992. 
DOE/ORP-2000-05, Rev. 1

04/2000

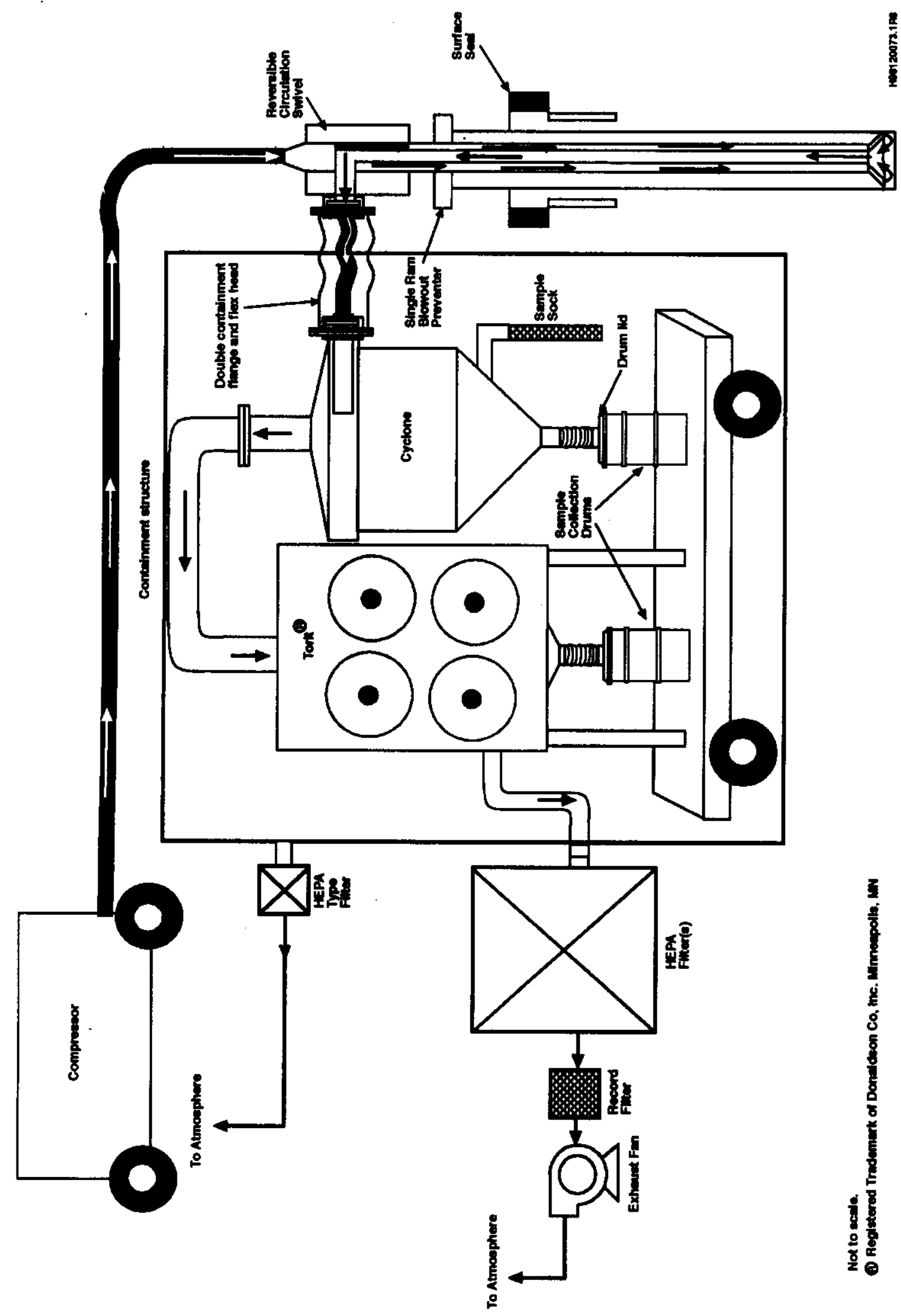

Figure 1. Process Flow Diagram 


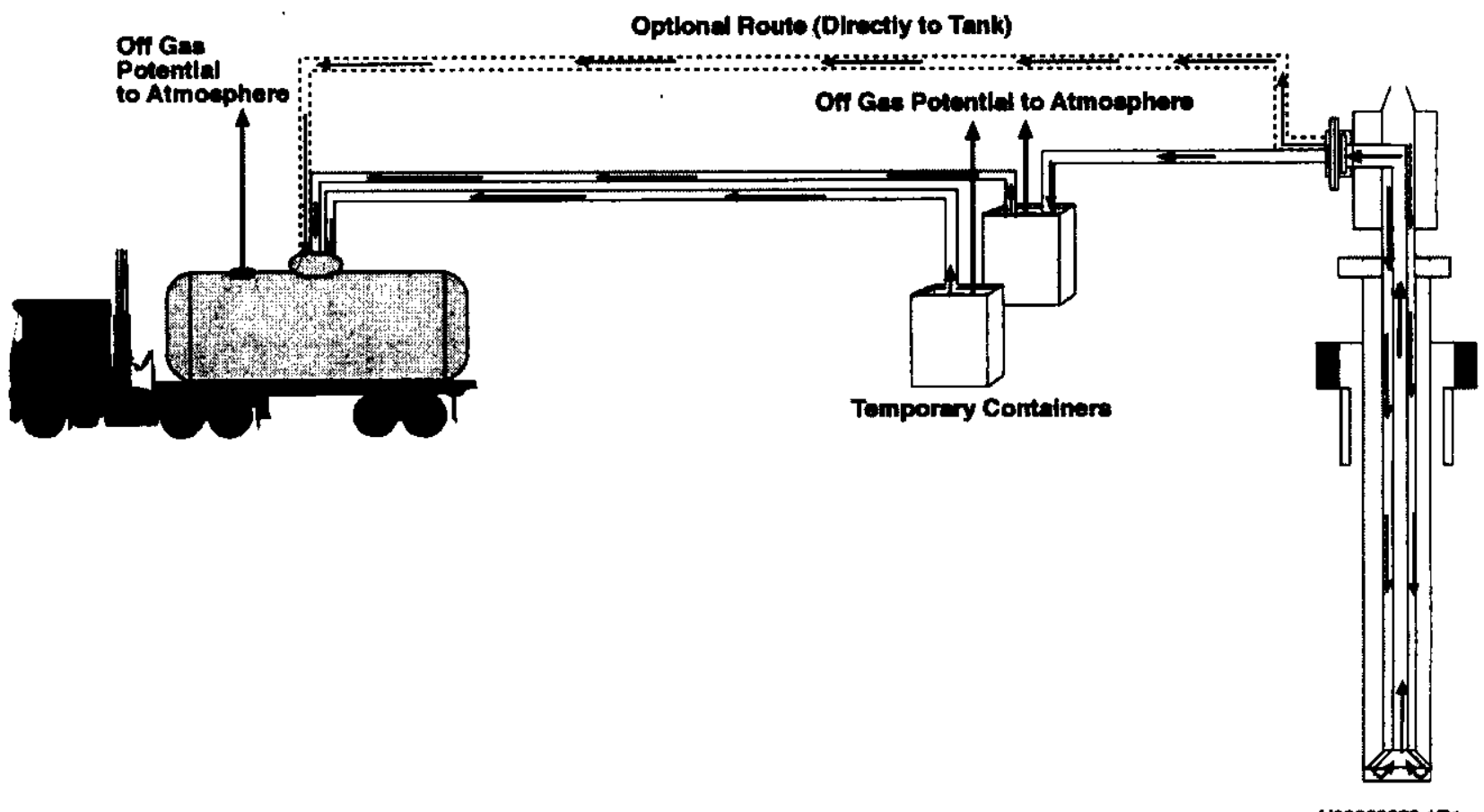

Figure. Flow Diagram for Handling Perched Water and Purgewater. 


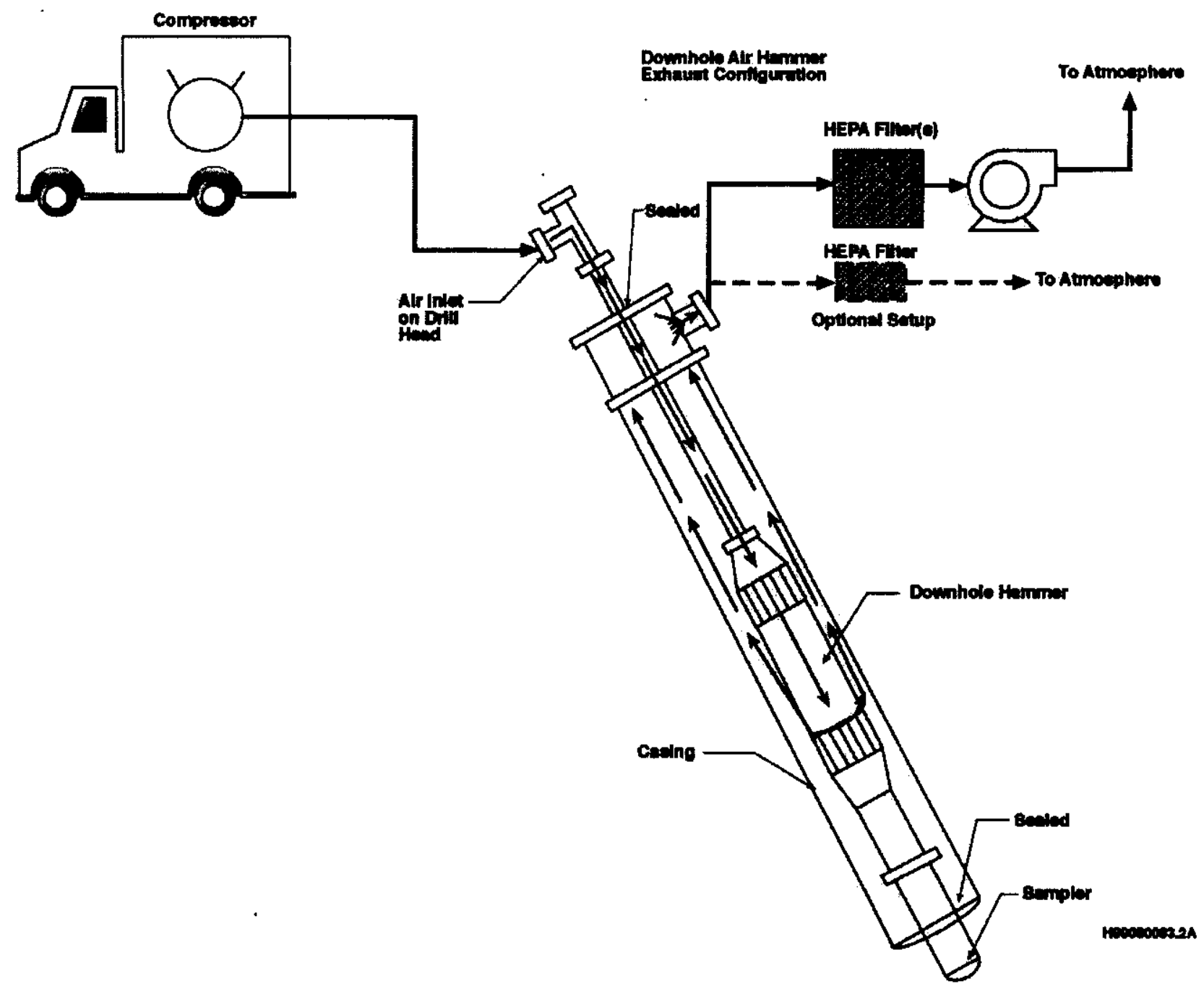

Figure 2. Air Hammer Ventilation System. 
DOE/ORP-2000-05, Rev. 1

$04 / 2000$

This page intentionally left blank. 


\section{ATTACHMENT A}

INSTRUCTIONS FOR BOREHOLE SAMPLING

(WHC-SD-EN-AP-181, REV. 0) 
This page intentionally left blank. 
WHC-SD-EN-AP-181, Rev. 0

\author{
INTRODUCTION
}

Geologic systems generally are complex with physical properties and trends that can be difficult to predict. Subsurface geology (including stratigraphy, mineralogy, geochemistry) exerts a fundamental control on groundwater flow and contaminant transport. Federal and state reguiations (Title 40, Code of Federal Regulations (CFR) Part 265.90(a), 40 CFR 265.90(c)(1)(ii), 40 CFR 265.90(2)(i), 40 CFR 265.91(a), Washington Administrative Code (WAC) 173-303-282, WAC 173-303806, WAC 173-200-080, WAC 173-160-050) require characterization of subsurface hydrogeologic conditions to allow for defensible calculations of flow and transport conditions, and to asses the impacts of the geology on groundwater and vadose zone conditions.

The primary source for direct observation of subsurface geologic information is a borehole. However, direct observations from a borehole essentially are limited to the diameter and spacing of boreholes and the quality of the information derived from the drilling. Because it is impractical to drill a borehole every few feet to obtain data, it is necessary to maximize the data gathered during linited drilling operations. A technically defensible balance between the customer's data quality objectives and control of drilling costs through limited drilling can be achieved with proper conduct of operations.

This report presents the minimum criteria for geologic and hydrologic characterization and sampling that must be met during drilling. It outlines the sampling goals that need to be addressed when drilling boreholes, and the types of drilling techniques that work best to achieve these goals under the geologic conditions found at Hanford. This report provides general guidelines for: (1) how sampling methods are controlled by data needs, (2) how minimum sampling requirements change as knowledge and needs change, and (3) when drilling and sampling parameters need to be closely controlled with respect to the specific data needs. Consequently, the report is divided into two sections that center on: (1) a discussion of basic categories of subsurface characterization, sarapling, and sampling techniques, and (2) guidelines for determining which drilling and sampling techniques meet required characterization and sampling objectives.

Data quality objectives for subsurface characterization in any given project are established in characterization plans, work plans, data sheets, and similar documentation. The guidelines outlined in this report are used to determine the appropriate drilling and sampling techniques necessary to achieve the stated objectives. This document is not intended to be used to establish the data quality objectives for a spectfic project, only to aid in achieving them. 
WHC-SD-EN-AP-181, Rev. 0

\section{SUBSURFACE SAMPLING}

Subsurface sampling is the main driving force of any characterization/ drilling program. Sampling during drilling can be grouped under general categories which relate to the data needs for a given project. These categories range from no sampling, to basic or gross scale sampling, to intermediate sampling, to detailed analysis. Depending on data needs and project objectives, different scales of sampling effort are necessary. Successful implementation of sampling, regardless of the type, is highly dependant on input from an experienced drilling engineer and the project geologist.

\section{Samoling Categories}

The basic rational, typical techniques, and situations for the different categories of sampling are outlined below:

1. No Sampling - In some situations a projects data quality objectives may not involve geologic/physical sampling. Under these circumstances it would be appropriate to not do any geologic sampling.

2. Basic Sampling - Basic sampling (also referred to as gross or grab sampling) is used to provide enough information to identify basic geologic features such as formation, member, and unit and to differentiate between major sediment types or facies. Under some circumstances, these samples also may be adequate for chemical and radiological screening. Basic samples typically consist of cuttings bailed from the borehole and/or removed from an air/fluid circulation stream. The geologist's ability to accurately interpret the geologic features represented by particular cuttings is directly dependant upon drilling factors such as lagtime, hole cleaning, over drilling, and excessive milling. Generaliy, basic sampling is done in areas were sufficient data already exists to meet project data needs, in areas were only confirmation of the most basic geologic information is needed, and as a scoping tool in areas where reconnaissance or exploratory drilling is being conducted.

3. Intermediate Scale - Intermediate sampling is done in areas where a moderate amount of data already exists and where project goals call for specific, limited technically defendable sampling. Such objectives include, but are not limited to, verification of stratigraphic picks. and facies types previously interpreted from cuttings and the collection of certain types of samples for specific analysis. Commoniy, this type of characterization may require that samples be called for anytime there is a need to establish a level of control or defensibility not attainable with drill cuttings alone. Appropriate techniques. for this sampling would include split spoons, sonic core barrel methods, and rotary coring.

4. Detailed - Detailed sampling, generally in the form of coring (e.g., rotary or sonic), usually is undertaken in areas where there is little 
WHC-SD-EN-AP-181, ReV. 0

or no accurate data to meet project data quality objectives. These needs range from physical data about formation geologic properties that is only obtainable from intact samples to specific sample requirements for analytical evaluation. Specific sample techniques are controlied by the types of samples needed and the geologic conditions (e.g., cemented vs. uncemented, or gravelly vs. silty).

\section{Establishing Sampling Categories}

Determining which sampling category is used during any given project is dependant on a clear definition of the data quality objectives. In order to determine the objectives, one must first evaluate the nature and quality of existing data applicable to a given project. Based on this evaluation specific project data needs (e.g., the data quality objectives) are .. identified and the requirements for borehole sampling established.

The existing data and data needs are usualiy identified in characterization and work plans written prior to the beginning of a drilling project. Data sheets for individual wells take the information from the work and characterization plans to identify drilling and sampling goals (e.g. sample categories) for a well, establish the type of sample required, and indicate the approximate sample intervals. The project geologist, in consultation with the client, is responsible for determining overail sampling needs, and the effectiveness and reliability of the samples retrieved during the project.

The following discussion lists two examples of how sampling categories are used in combination to achieve specific data quality objectives:

1. For many projects adequate well coverage and data to address most, if not all, data quality objectives already exists. In these situations new drilling and sampling will center. on correlating the geology encountered in the new wells to preexisting wells, and sampling will consist dominantly of category 2 methods. Some category 3 sampling to verify stratigraphic/facies picks will be undertaken if it is determined to be.necessary. Occasionally, category 4 sampling will undertaken if site specific data quality objectives must be met. In some cases if no additional information is required no sampling would be needed (i.e., sampling category 1 ).

2. For some projects 1fttle or no data applicable to the project objectives may exist. Consequently, drilling for this project relies heavily on sampling categories 3 and 4 in. order to establish site specific data and tie the new site to other, previousiy characterized locations.

During any given project, the scale of the sampling effort is 1ikely to change. For example, as data from drilling is assimilated, the level of the sampling effort may decrease (e.g., from categories 4 to 3) as data quality objectives are met. Another example of conditions under which a 
WHC-SD-EN-AP-181, Rev. 0

scale-down in sampling may occur is in situations where drilling conditions are such that intact cores (category 4) simply can not be obtained. Under many circumstances a scale up in sampling effort is necessary. This typically happens when previously unforeseen geologic conditions are encountered during driling and it is determined that more detailed sampling is necessary to meet the project data quality objectives.

\section{SAMPLING TECHNIQUES}

Sampling techniques and sampling categories are closely related and, in practice, essentialiy inseparable. Inappropriate sampling techniques for the geologic conditions encountered limits the ability to recover a representative sample, and consequentiy leads to decreased accuracy and reliability in the analysis performed. During subsurface geologic sampling, data needs and formation conditions must be considered when determining the appropriate drilling/sampling techniques to collect the required data.

Tables 1 and 2 compare various fjeld and analytical samples to different drilling techniques to show which techniques are more appropriate for the kind of analysis planned. These comparisons take the form of a yes (Y) or no (N) to show whether a particular drilling method has a reasonable chance of acquiring a sample adequate for a given analysis or data need. In many cases the yes/no response is marked by a number that corresponds to a footnote following the tables. These footnotes list basic considerations that need to be taken into account for the specific drilling techniques and sampling requirements. These considerations center on two fundamental areas of critical importance to the acquisition of representative

subsurface samples: (1) geologic or formation conditions, and (2) drilling technique and rig operation.

Table 1 lists the descriptive parameters that well site geologists commonly consider when providing general subsurface geologic descriptions. In addition, the parameters listed in Table 1 generally represent the minimum data requirements necessary for the field geologist to identify subsurface samples that meet sampling criteria established in the characterization plans and data sheets.

Table 2 lists analyses typically done on borehole samples and compares them to the various drilling techniques. This table shows that a number of drilling techniques are not appropriate for the types of analysis requested for many of the samples collected on the Hanford Site. The table can be used to establish the drilling technique needed to acquire samples for the analyses required to meet the project data quality objectives. If the drilling criteria for the specific analyses outlined in Table 2 cannot be met, the data quality objectives for the project will not be met. In such cases the selected drilling/sampling techniques need to be reassessed. 
WHC-SD-EN-AP-181, Rev. 0

Table 1. Field Criteria

\begin{tabular}{|c|c|c|c|c|c|c|c|c|}
\hline & $\begin{array}{l}\text { Anger } \\
\text { solid } \\
\text { atem }\end{array}$ & ntit & 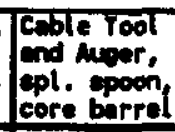 & $\begin{array}{l}\text { Soncic core } \\
\text { barret and } \\
\text { applit apoon } \\
\end{array}$ & $\begin{array}{l}\text { Air Rothry, } \\
\text { cuttenges }\end{array}$ & $\mid \begin{array}{l}\text { Rir Rotary. } \\
\text { eplit apoon }\end{array}$ & pud Rotary & $\begin{array}{l}\text { Rothy } \\
\text { coring }\end{array}$ \\
\hline $\begin{array}{l}\text { Relotive } \\
\text { moleturure } \\
\text { gset EII } \\
9.1)\end{array}$ & $w^{2}$ & $n$ & $r^{1}$ & $x^{9}$ & n & $r^{6}$ & w & $y^{1}$ \\
\hline 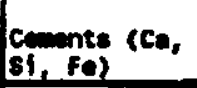 & $r^{10} / m^{2}$ & $y^{11}$ & $r^{4}$ & $r$ & $\mid r^{3,10}$ & $r^{6}$ & $r^{10}$ & $y$ \\
\hline $\begin{array}{l}\text { Colors } \\
\text { str) }\end{array}$ & $\mu^{2}$ & $n$ & $r$ & $r / m^{5}$ & $r^{3,12}$ & $\gamma$ & $r^{12}$ & $\mathrm{r}$ \\
\hline $\begin{array}{l}\text { Lith.. } \\
\text { textures (1 } \\
\text { phi) }\end{array}$ & n & $\mu$ & $r^{4}$ & $r / x^{5}$ & $r^{3,12}$ & $r^{4}$ & $\gamma^{12}$ & 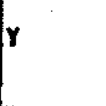 \\
\hline Lith & $n^{13}$ & $N^{13}$ & $r$ & $Y / N^{5}$ & $r^{3}$ & $r$ & $\mid \begin{array}{l}\text { y-uneon } \\
\text { Yenconeol; } 12 .\end{array}$ & $Y$ \\
\hline 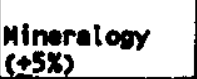 & $w^{2}$ & $\mid n^{6,12}$ & $r^{4}$ & r & $y^{3}$ & $r^{4}$ & w & $r$ \\
\hline
\end{tabular}

Explanations of parameters used in Table 1.

Cements - The basic nature and characteristics of cementing agents need to be identified because of their fundamental control on hydrologic properties such as high and low flow zones. Cementing agents typically present include calcium carbonate, silica, ferro-magnesfum oxides, and muds.

Colors - Color changes are often an important indicator of unit and. facies changes. As such they need to be readily identified. Changes in color need to be identified within 1 foot of actual occurrence.

Lith., textures - Lithologic texture essentially refers to grain size. Grain size variations down to 1 phi have to be identifiable in the sand to stall pebble range.

Lith., bedding - Resolution of stratigraphic features within $2 \mathrm{ft}$ of their actual occurrence is necessary to identify facies changes important to hydrologic flow systems and to pick major formational and stratigraphic unit contacts.

Mineralogy - In fine-grained sand and larger sizes the field geologist should be able to identify major mineral types (e.g. basalt, quartz, feldspar, micas, etc.) and estimate abundance by volume to $\pm 10 \%$. Below the fine-grained sand size geologist cannot identify. mineralogy by hand lens. 
WHC-SD-EN-AP-181, Rev, 0

Table 2. Analytical Criteria

\begin{tabular}{|c|c|c|c|c|c|c|c|c|}
\hline & \begin{tabular}{|l|} 
Auger, \\
sol id stem
\end{tabular} & Table Tool, $_{\text {HT }}$ & $\begin{array}{l}\text { Cable Yool } \\
\text { and Auger, } \\
\text { spl.spoon, } \\
\text { core berrel }\end{array}$ & $\begin{array}{l}\text { Sonic core } \\
\text { berral and } \\
\text { sppltt } \\
\text { spoon }\end{array}$ & \begin{tabular}{|l}
1 R Rotary, \\
cuttings
\end{tabular} & $\begin{array}{l}\text { Air Rotary, } \\
\text { spl it apoon }\end{array}$ & $\begin{array}{l}\text { Wed Rotary } \\
\text { cuttings }\end{array}$ & $\begin{array}{l}\text { Rotary } \\
\text { Coring }\end{array}$ \\
\hline Moisture & H & $n$ & $y^{1}$ & $N^{9}$ & u & $y$ & W & $y^{1.7}$ \\
\hline $\begin{array}{l}\mathrm{CaCO}_{3} \text {; } \\
\text { cempents }\end{array}$ & $n^{2}$ & $N$ & $y$ & $\gamma$ & $r^{3}$ & $Y$ & $r$ & $r$ \\
\hline sieve & $\mathrm{N}^{2}$ & H & $r^{4}$ & $y$ & $y$ & $y^{4}$ & in & $r$ \\
\hline $\begin{array}{l}\text { Specific } \\
\text { Grevity }\end{array}$ & N & $N$ & $r^{4}$ & $y / x^{5}$ & $\omega$ & $r^{4}$ & $\cdots$ & $y$ \\
\hline $\begin{array}{l}\text { Density, } \\
\text { Porosity } \\
\left(>3.5^{\circ}\right)\end{array}$ & N & $N$ & $r^{4}$ & $r / \mu^{5}$ & $n$ & $r^{4}$ & $\mu$ & $\dot{\gamma}$ \\
\hline $\begin{array}{l}\text { Unsat \& sat K } \\
(>3.511)\end{array}$ & N & N & $y^{4}$ & $y / N^{5}$ & H & $y^{4}$ & $N$ & $y$ \\
\hline $\begin{array}{l}\text { Moisture } \\
\text { Retention }\end{array}$ & N & N & $r^{4}$ & $y / N^{5}$ & N & $y^{4}$ & $N$ & $y$ \\
\hline XRD Min. & $N^{2}$ & N & $r^{4,8}$ & $y$ & $r^{3}$ & $r^{4,8}$ & $r^{3}$ & $y$ \\
\hline XRF Geochem. & $H^{2}$ & N & $r^{4,8}$ & $y$ & $y^{3}$ & $r^{4,8}$ & $r^{3}$ & $Y$ \\
\hline Thin sec. & $N^{2}$ & L & $r^{4,8}$ & $y$ & $r^{3}$ & $r^{4,8}$ & $y^{3}$ & $y$ \\
\hline Chemical & $\mathrm{N}^{2}$ & $N$ & $\gamma$ & $\begin{array}{c}\text { yonvol: } \\
\text { nolatile } \\
\text { velle }\end{array}$ & $N$ & $y$ & M & $\gamma^{7}$ \\
\hline
\end{tabular}

Density, Porosity and Unsat. and Sat. K - A minimum 3.5 inch diameter sample needs to acquired on sample runs less than 10 feet long. If sampling runs longer than $10 \mathrm{ft}$ are being done sample minimum diameter will be 2.5 inch.

Footnotes to Tables 1 and 2.

1. If fluid not added.

2. Mixing of cuttings with borehole wall during transport of cuttings up auger flights limits use. 
WHC-SD-EN-AP-181, Rev. O

3. Assumes a reasonable lag time of no more than $20 \%$ over calculated 1 ag $t$ ime based on an uphole velocity of $6000 \mathrm{ft} / \mathrm{min}$. less than $1 \mathrm{ft}$ of slough in the borehole, absence of significant overmilled material, and position of drill bit is as per manufacturers spec for the system in use.

4. Best applied in unconsolidated to consolidated muds and sands. Will not work well in gravelly or cemented deposits because driving the sampler into these sediment types will break and fracture formation materials. Anything recovered from the sampler under these circumstances will not be intact.

5. Sonic core barrel samples in many cases show evidence of having expanded at some point during drilling (e.g. rig will drill $5 \mathrm{ft}$ but sample will fill a $10 \mathrm{ft}$ of core barrel). Expansion commonly results in the destruction of bedding features. As yet, the cause and extent of expansion is not clearly understood, making it difficult to determine if many samples are representative of true formation conditions. Whether or not expansion has occurred needs to be determined in order to decide if a yes or no applies.

6. Fines are generated while driving the sampler because of abrasion and breaking of formation materials. Also have to have clean boreholes to insure recovery of representative sample.

7. Mud rotary core may alter.

8. In crystalline and homogeneous sedimentary rocks should work well. In heterogeneous deposfts have to assume an ability to separate grains broken during drilling from those that are unbroken. As a consequence, this may only be usable in gravel-poor formations and uncemented strata.

9. Temperatures measured during drilling are too high for reliable estimates of moisture content and sampling of volatile materials.

10. Can use observed differences in drilling responses, e.g. chattering, torque, changing advance rate, bucking, etc; to determine at least the presence or absence of cement.

11. Gross scale observations (changes over several feet), based on advance rate. Small scale features such as individual beds and changes over just a few feet are difficult to identify.

12. Gross scale resolution of such things as beds over several feet thick and formational and member contacts is based on first arrivals of a particular parameter. Small scale features such as individual beds and changes over just a few feet are difficult to identify.

13. The exception is formational and high contrast member/unit contacts that are based on major, large scale parameters such as very different colors, textures, etc. 
WHC-SD-EN-AP-181, Rev. 0

14. Resolution of bedding is incumbent upon whether or not features are actualiy present. Knowing this is dependant upon good regional and facies knowledge typically acquired from outcrop analogues and intact cores.

\section{CONCLUSIONS}

Accurate subsurface characterization is dependant on the acquisition of representative geologic samples. To acquire such samples, the appropriate drilling technology must be matched to a projects stated data needs. These data needs, presented as part of the data quality objectives, should be found in planning documents (such as the characterization plan, drilling plan, and data sheets) for any given project. The guidelines outlined in this report can then be used by the project staff, in consultation with the client, to determine the specific drilling techniques necessary to obtain the stated data quality objectives for subsurface characterization. 
DOE/ORP-2000-05, Rev. 1

$04 / 2000$

\section{ATTACHMENT B}

TANK INVENTORY DATA 
DOE/ORP-2000-05, Rev. 1

$04 / 2000$

This page intentionally left blank. 


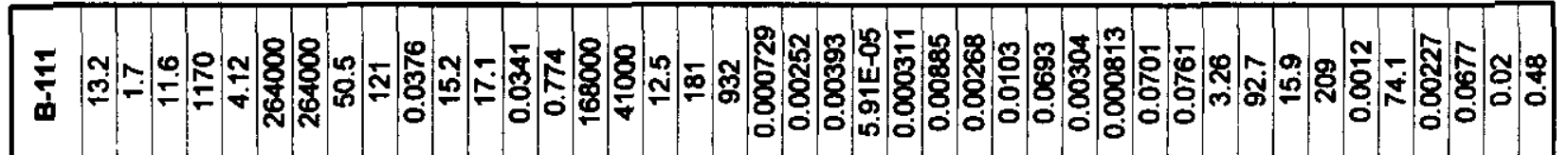

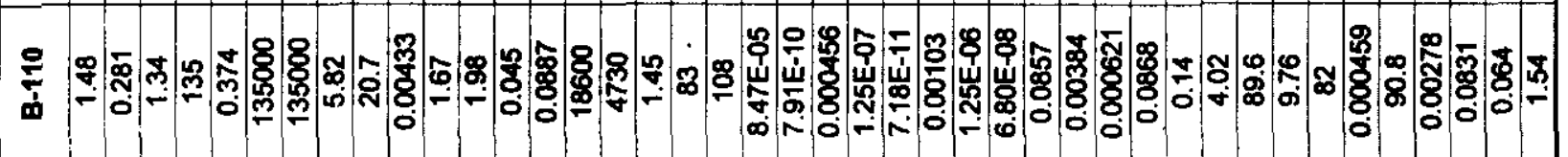

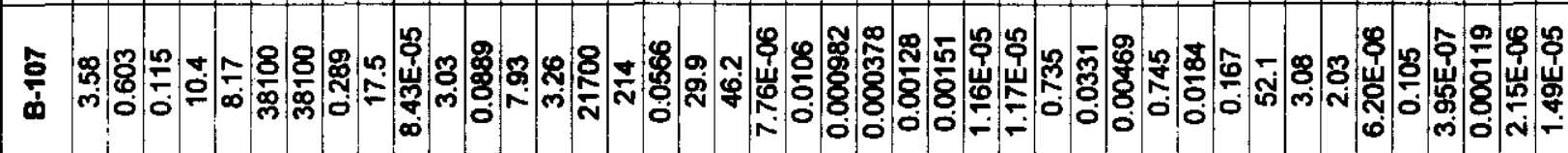

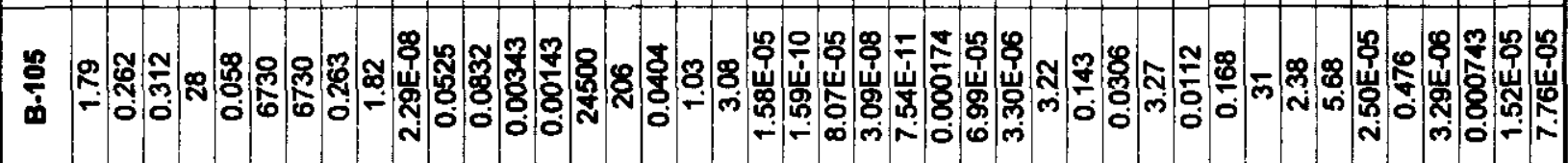

\%

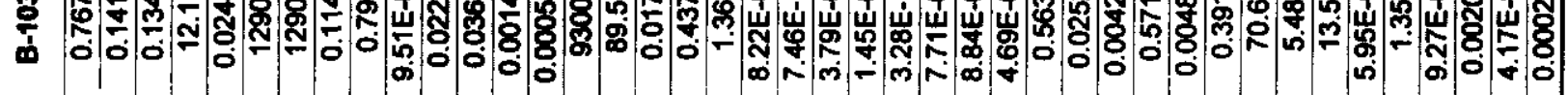

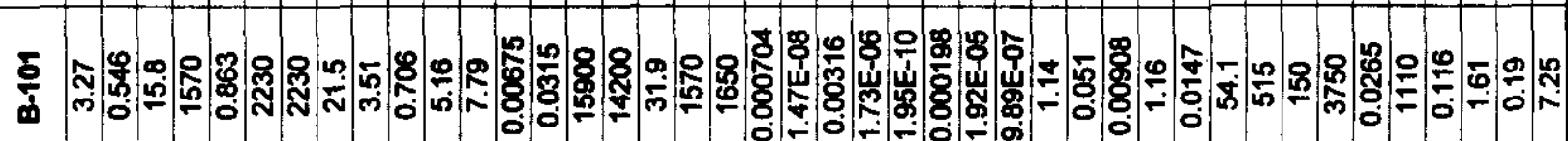

安

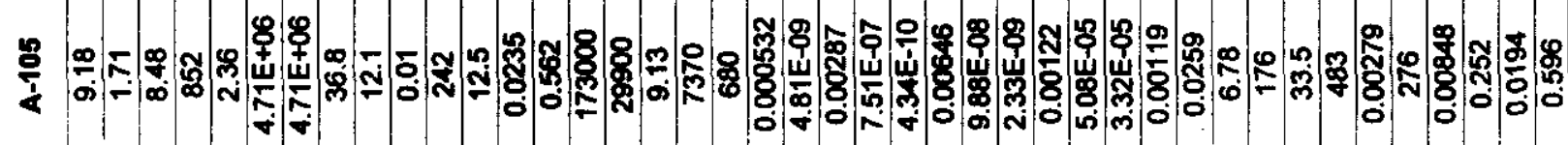

产

\&

量

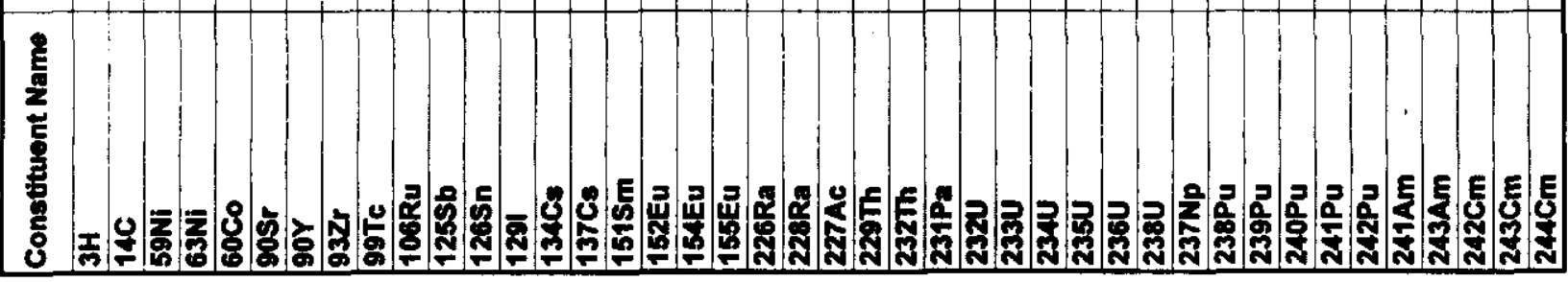


里 商竞| 室 F 产

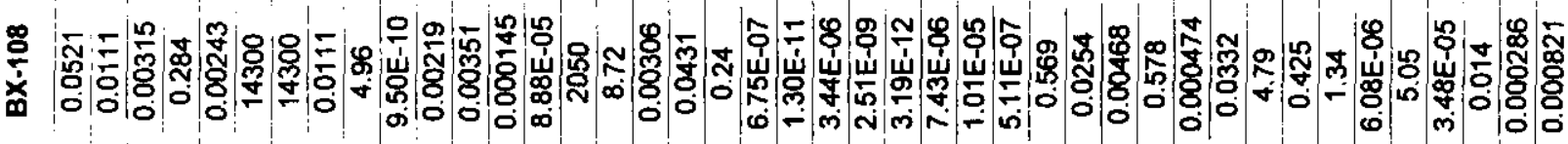

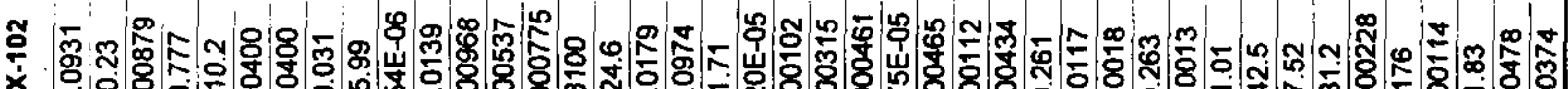

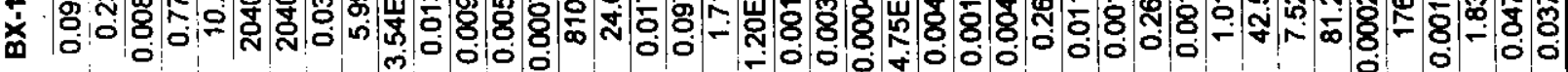

๖ 畜

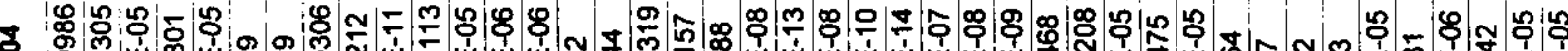
志 由

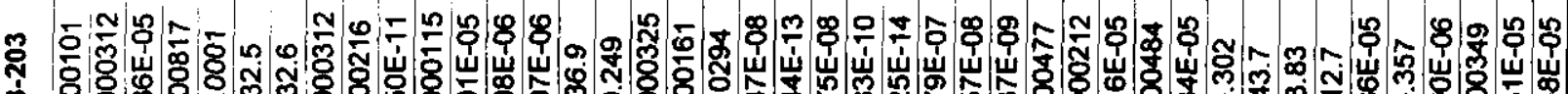
m ร

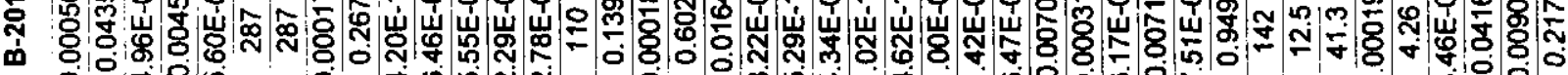

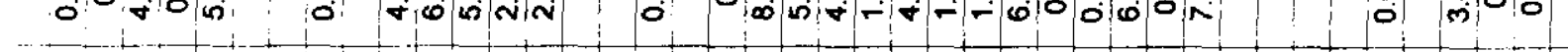
₹

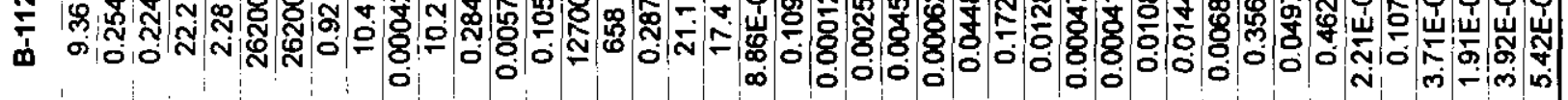

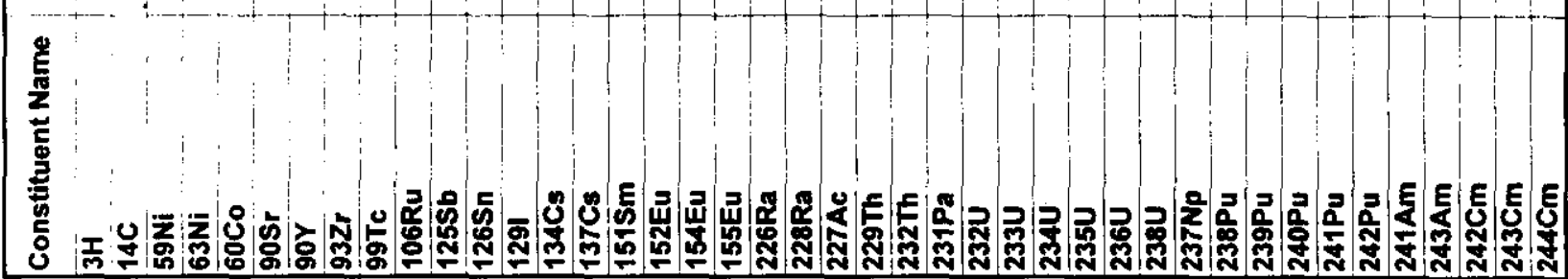




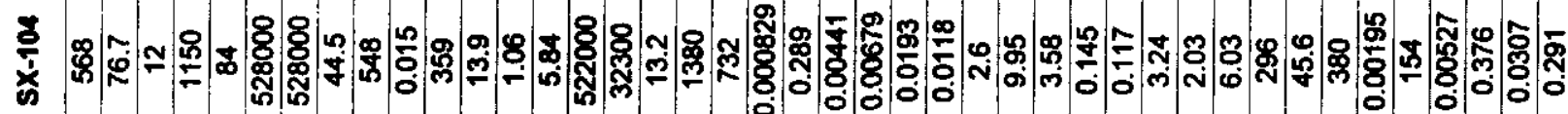

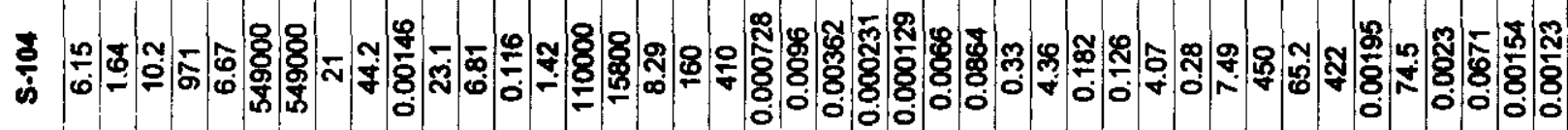

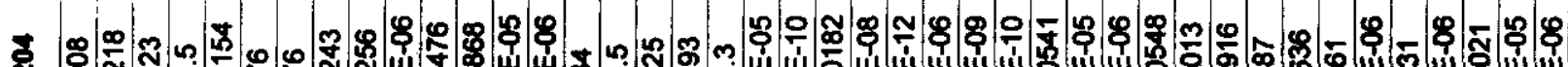
总 蛋 出

₹

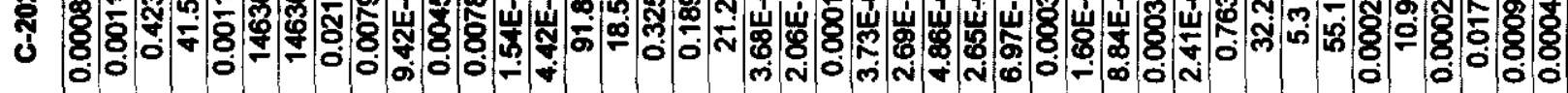

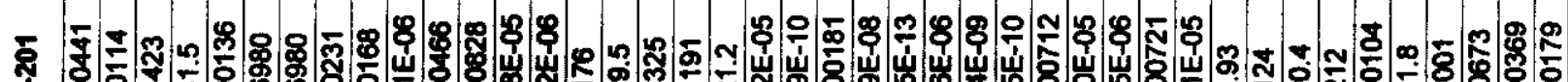
空 F 8 舟 J゙

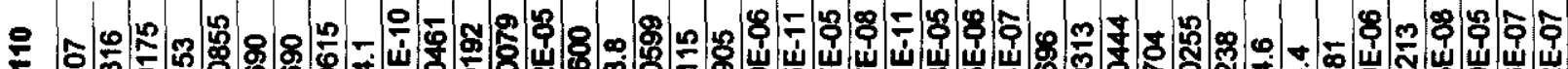
亏

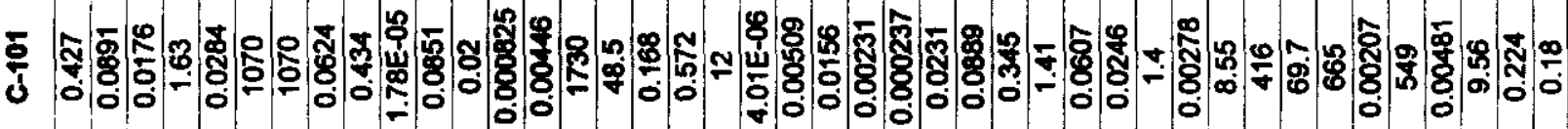
\% 前 市

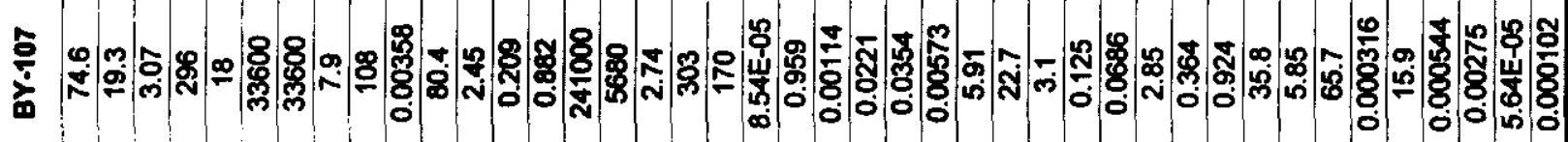

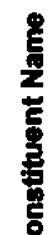


m 芒

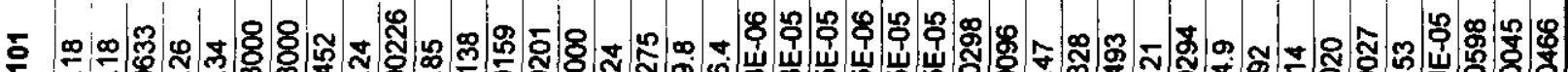
至

\%

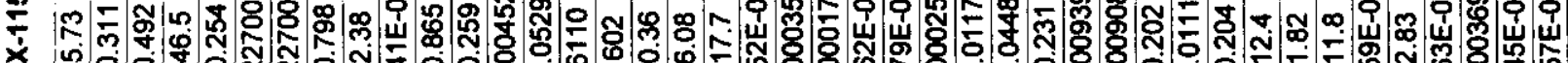
希

妾

m テ 产

产

产

울

离

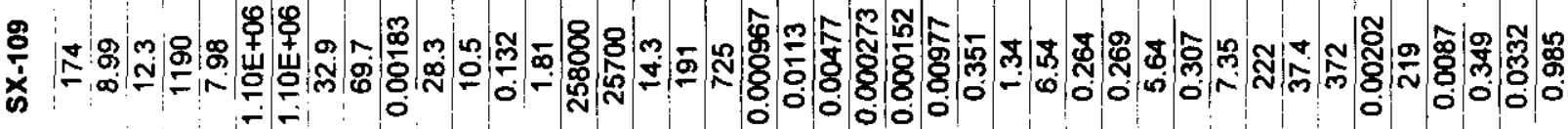

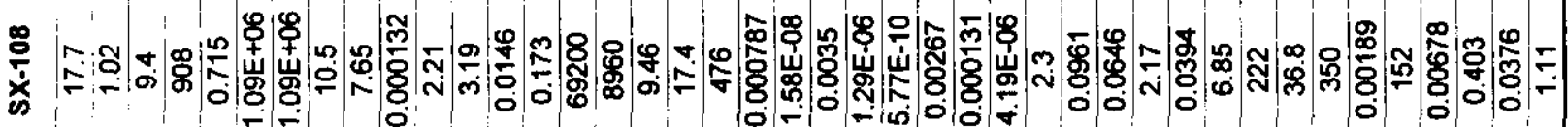

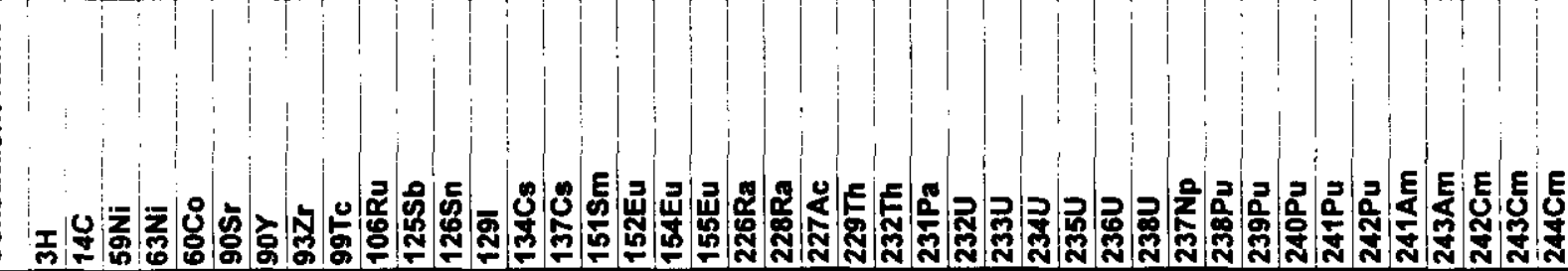




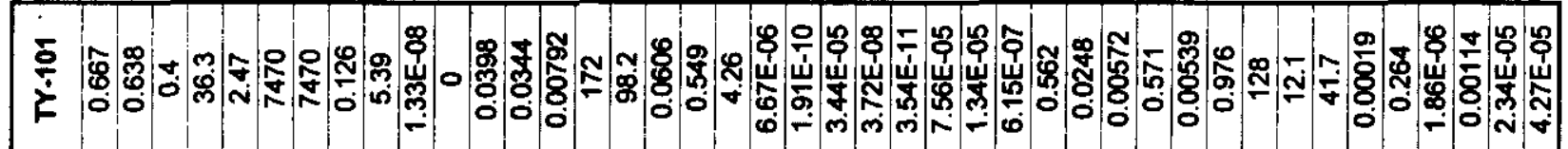

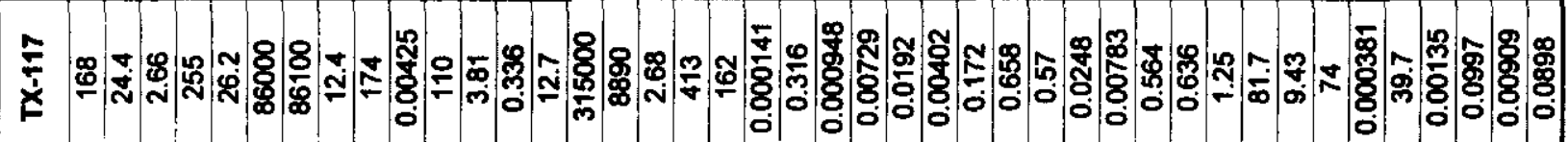
立

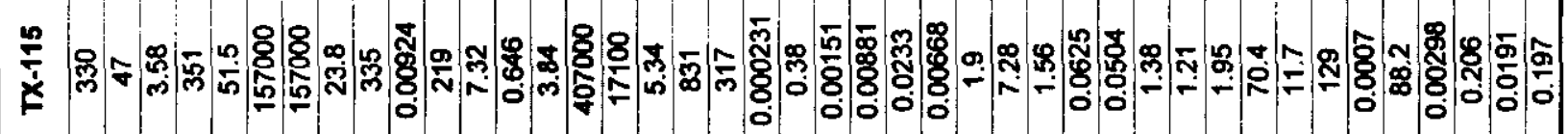

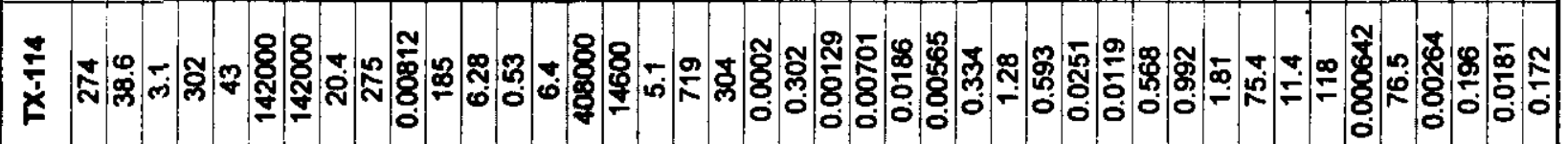
紊

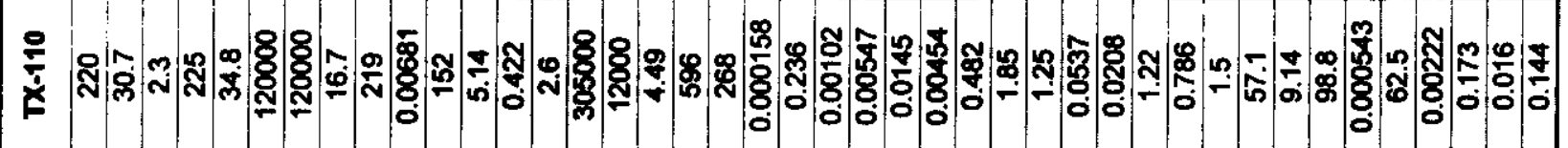

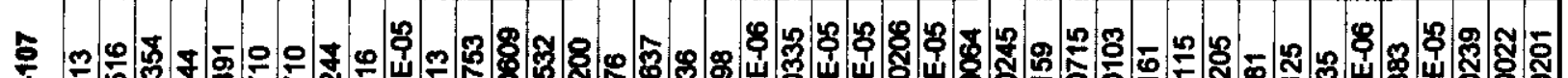
交

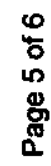

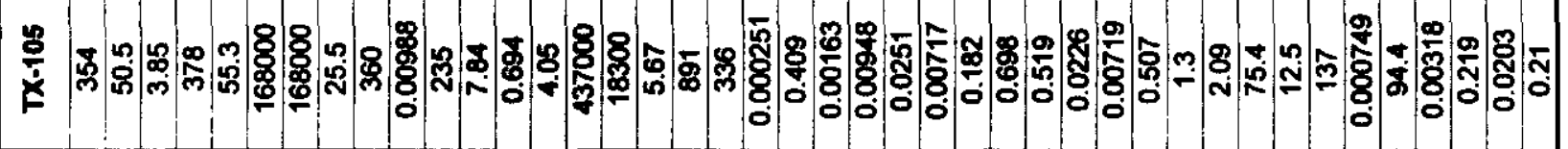

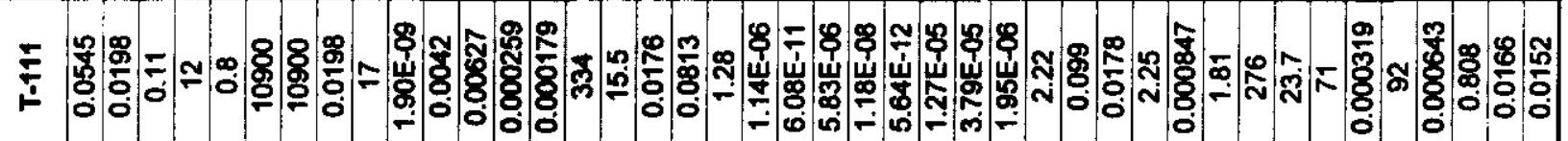

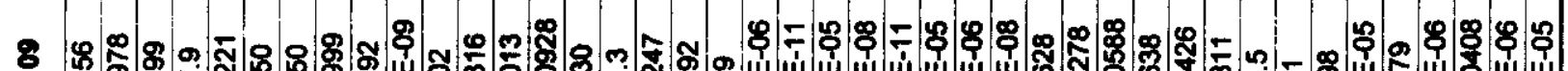

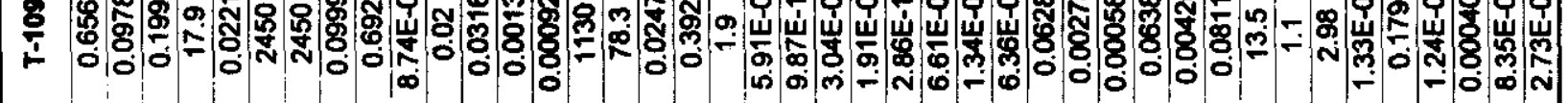

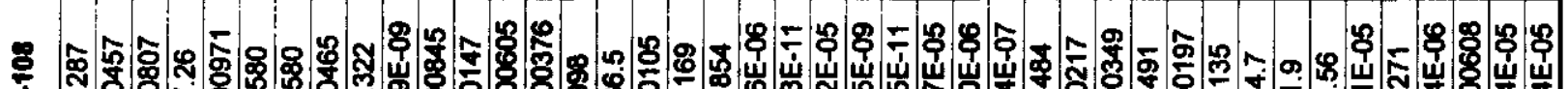

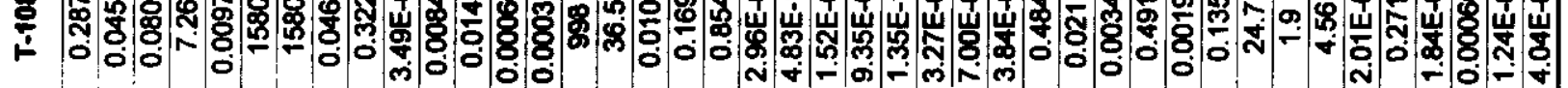

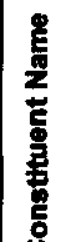

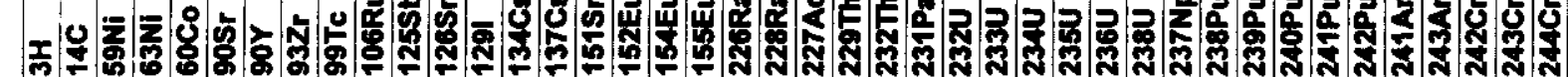




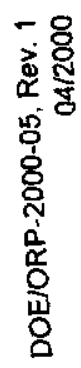

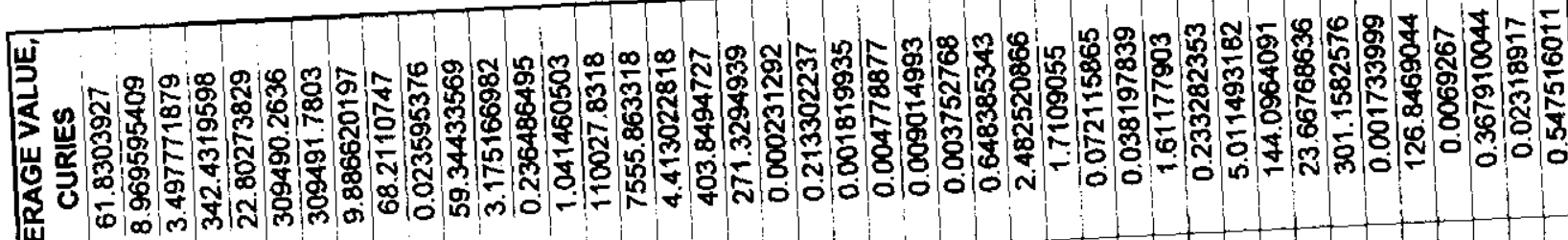

蛋

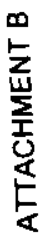

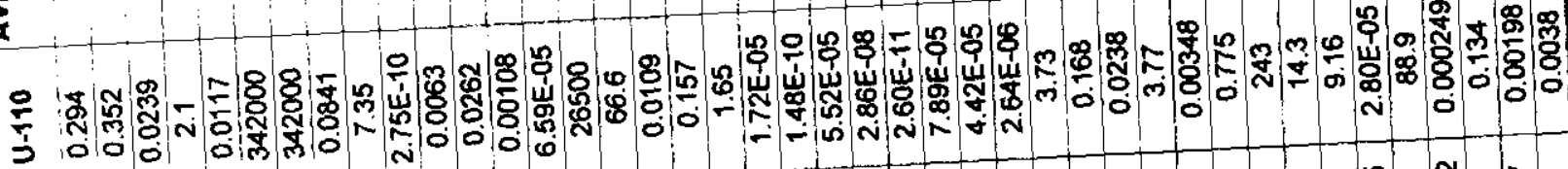

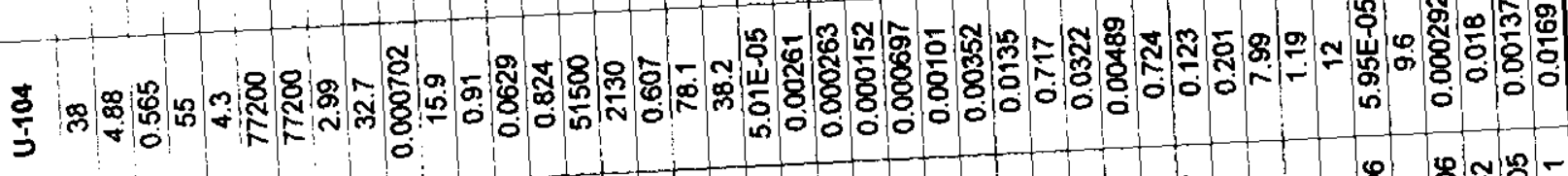

₹

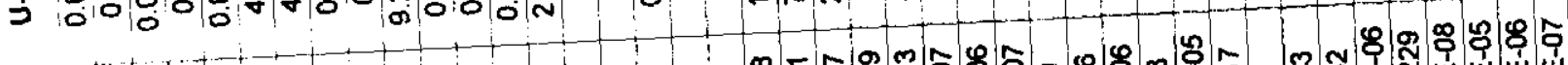

\%

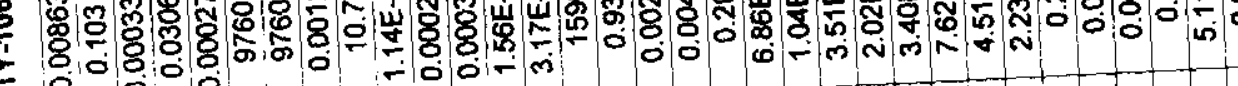
里 N

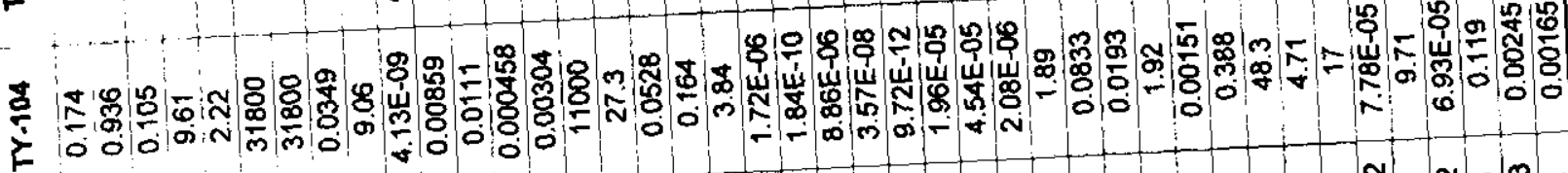

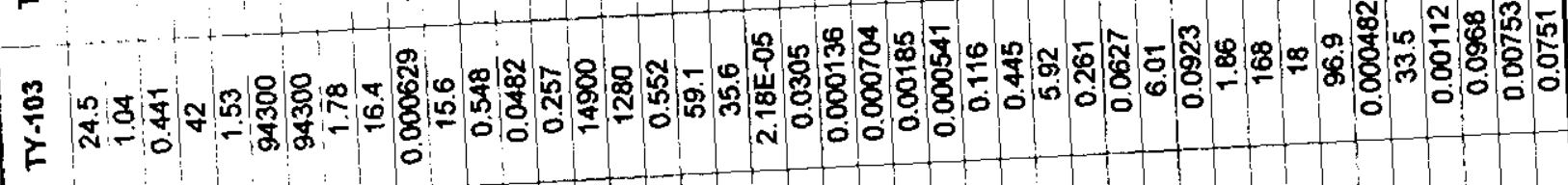
总

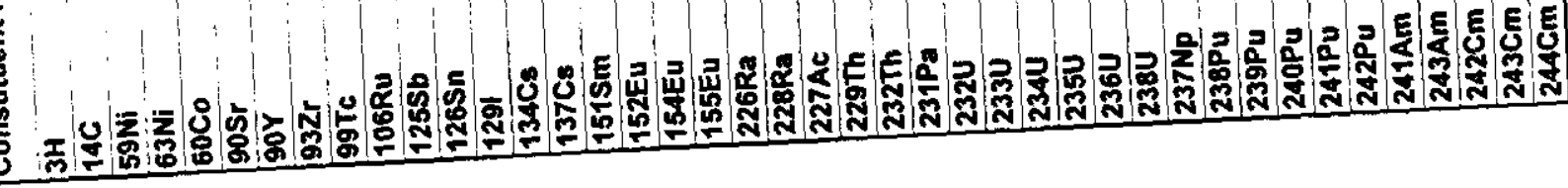


ATTACHMENT C

TANK ISOTOPE TO CESIUM-137 RATIOS 
This page intentionally left blank. 


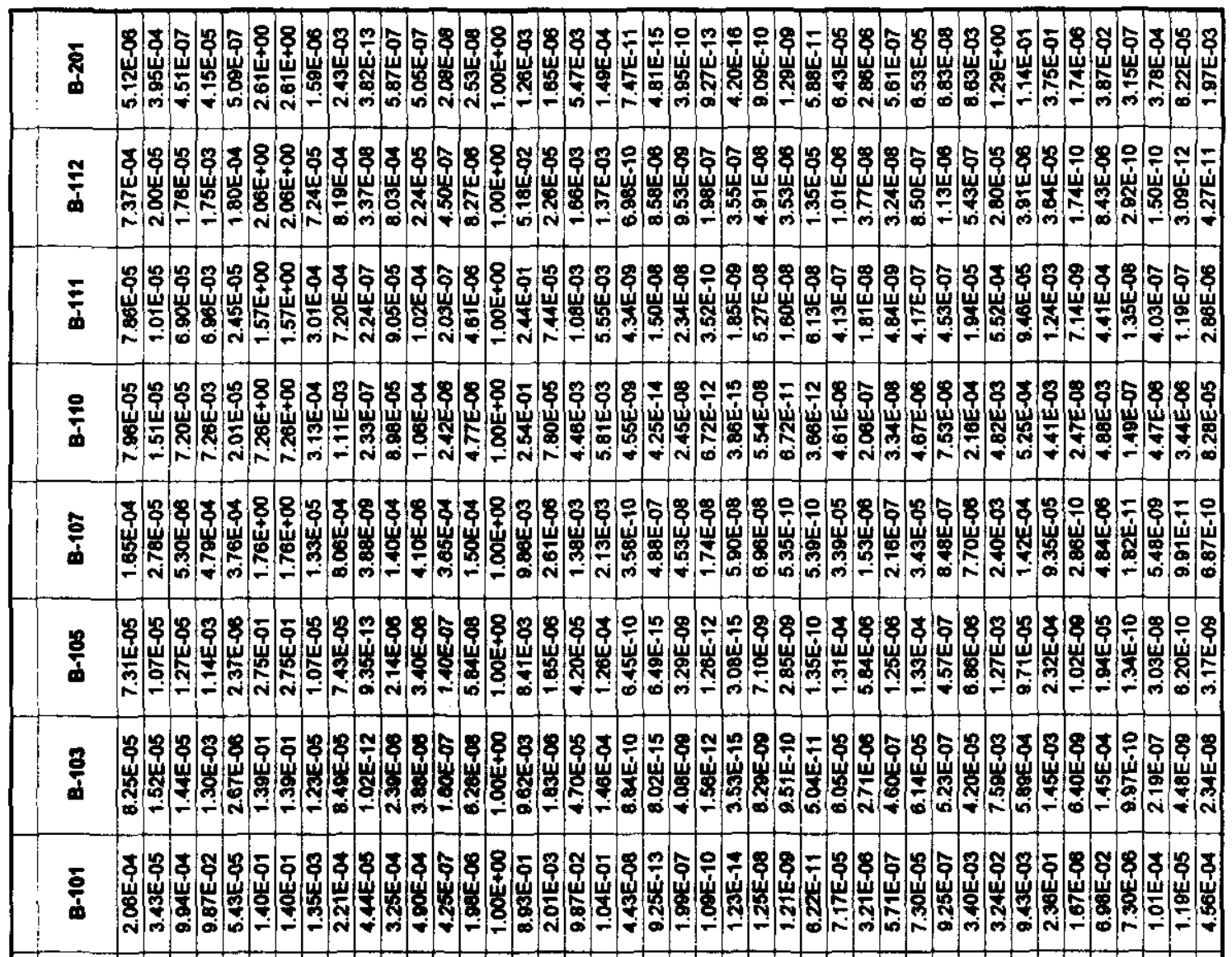

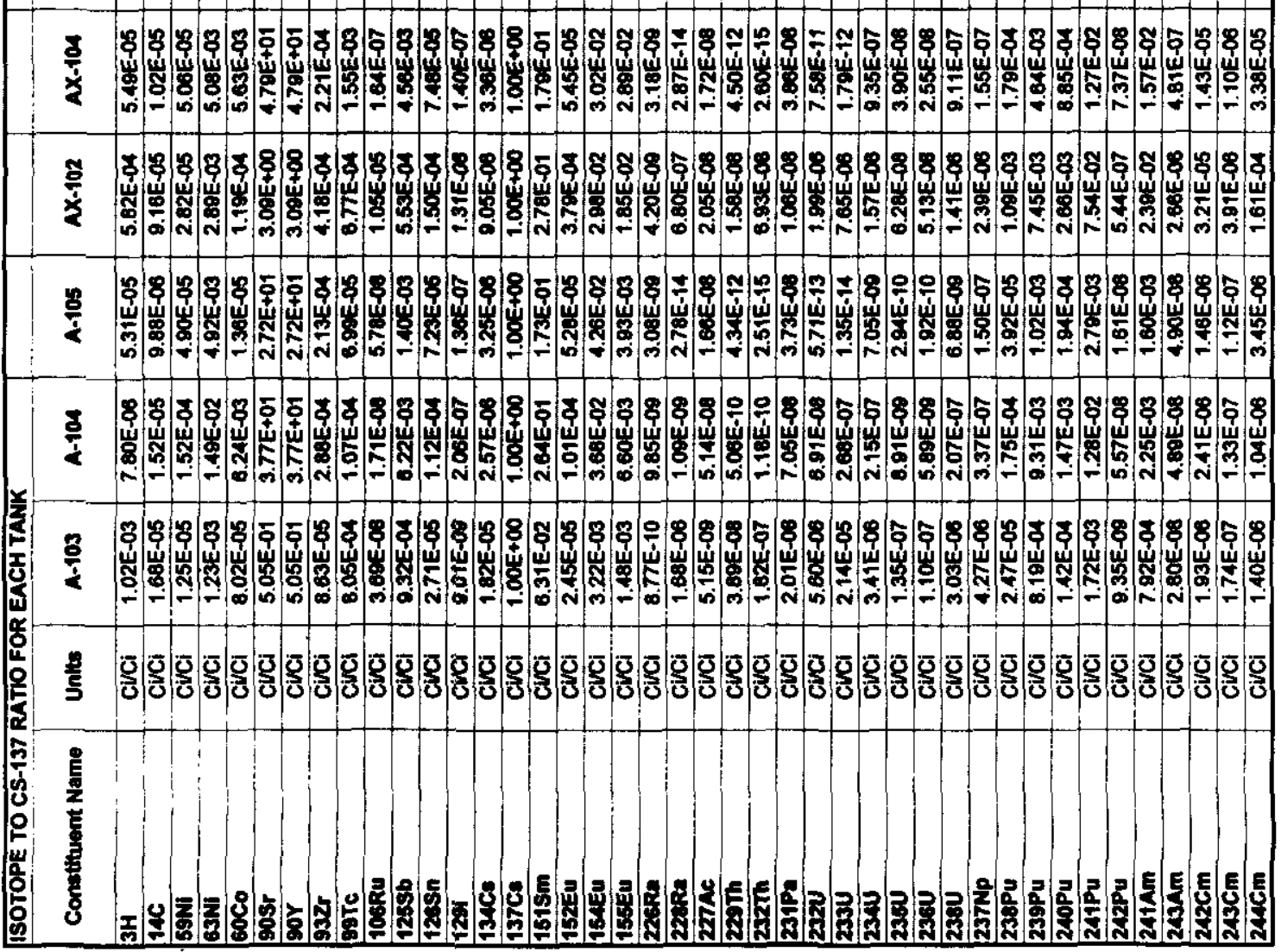


This page cannot be converted.

Please view the native document

for the original page. 
क

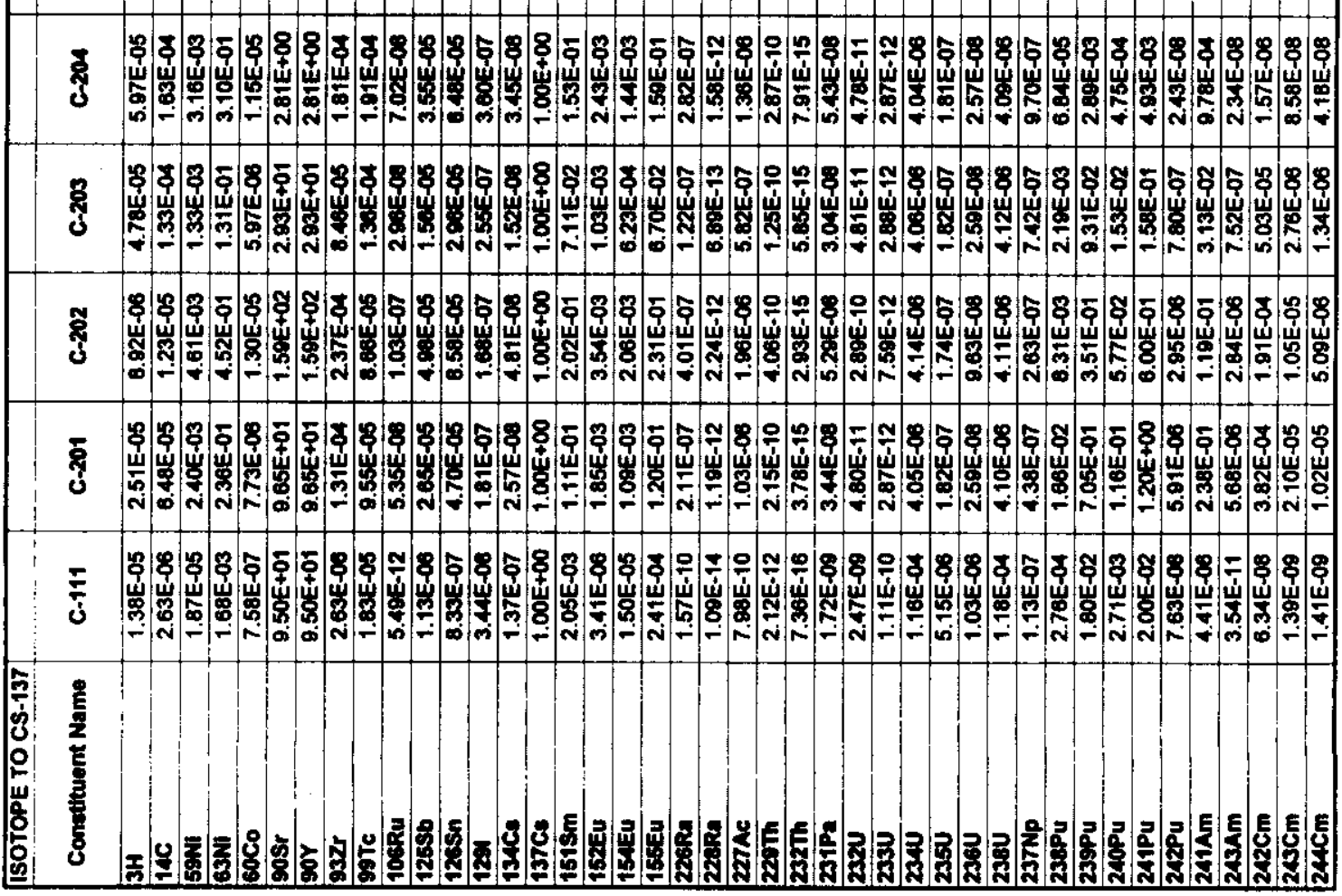




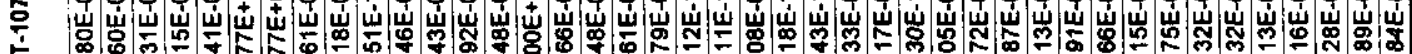

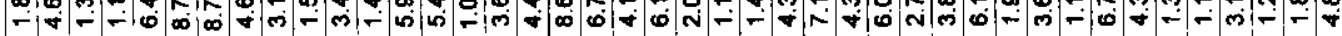

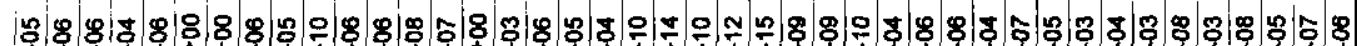

| |

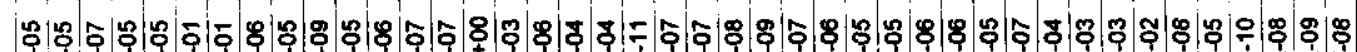

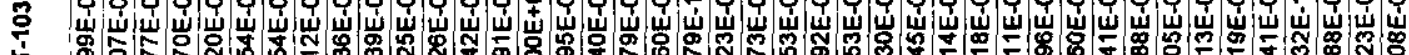
I

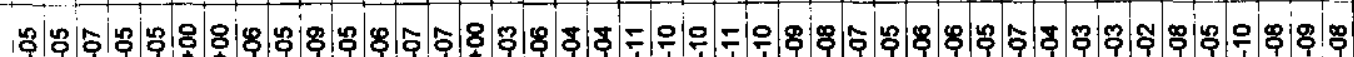

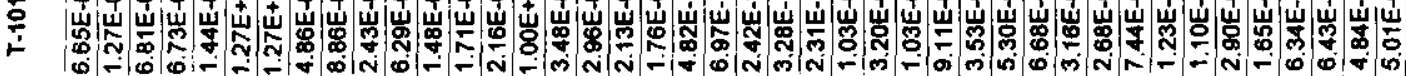

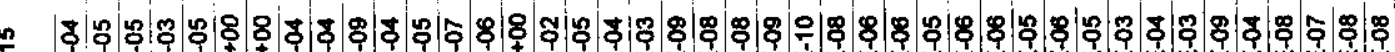

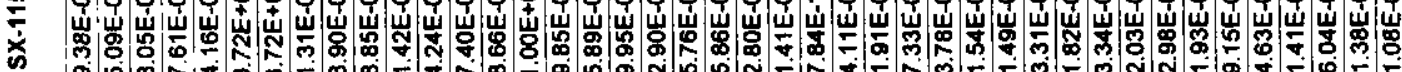

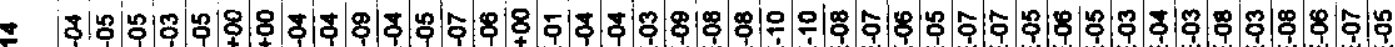

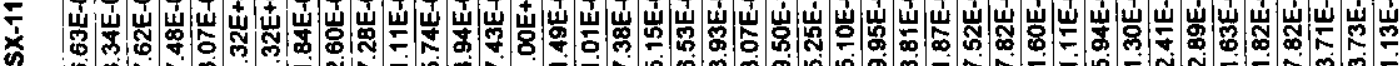

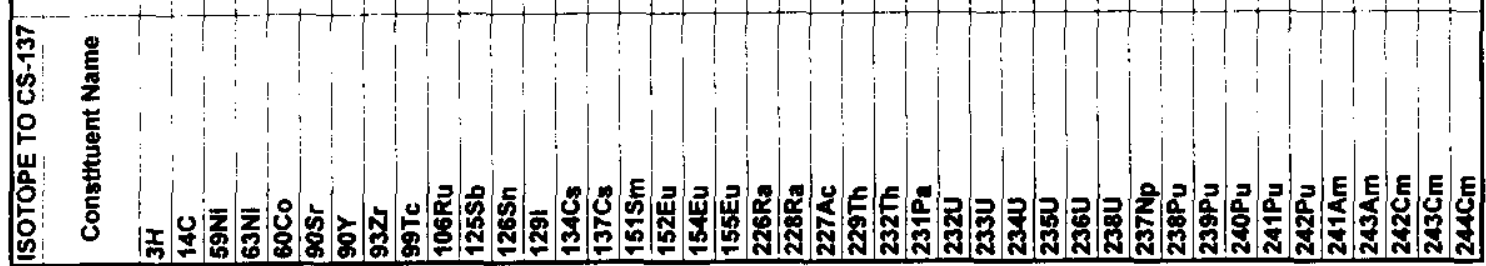




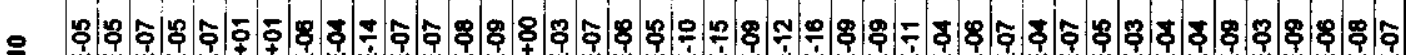

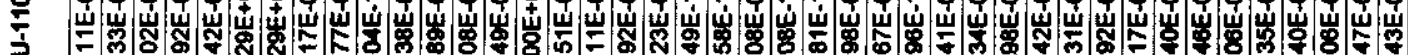

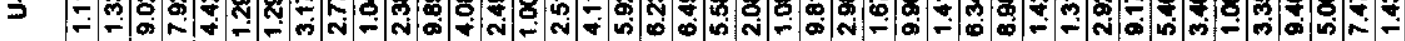

-

方

8)

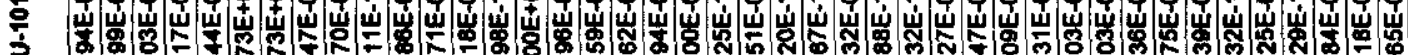

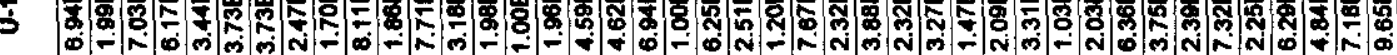

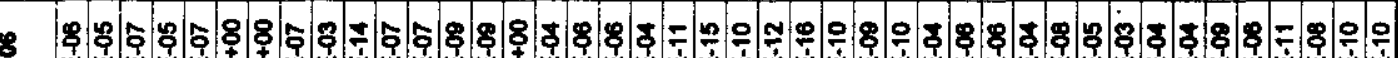

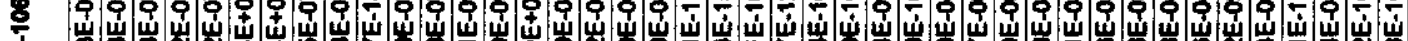

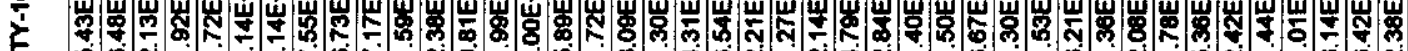

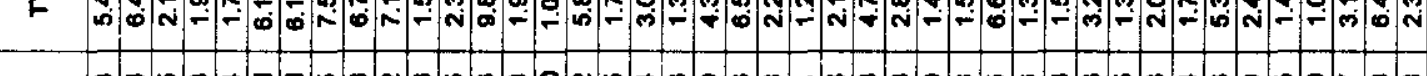

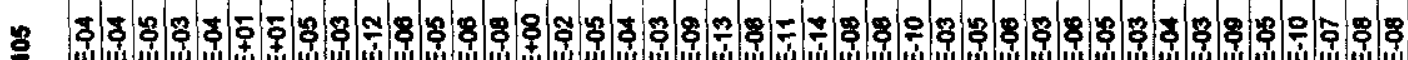

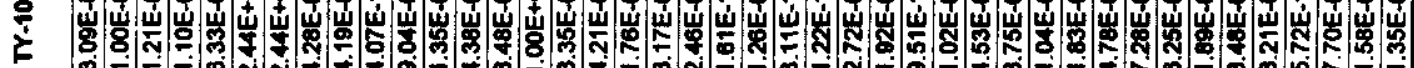
急

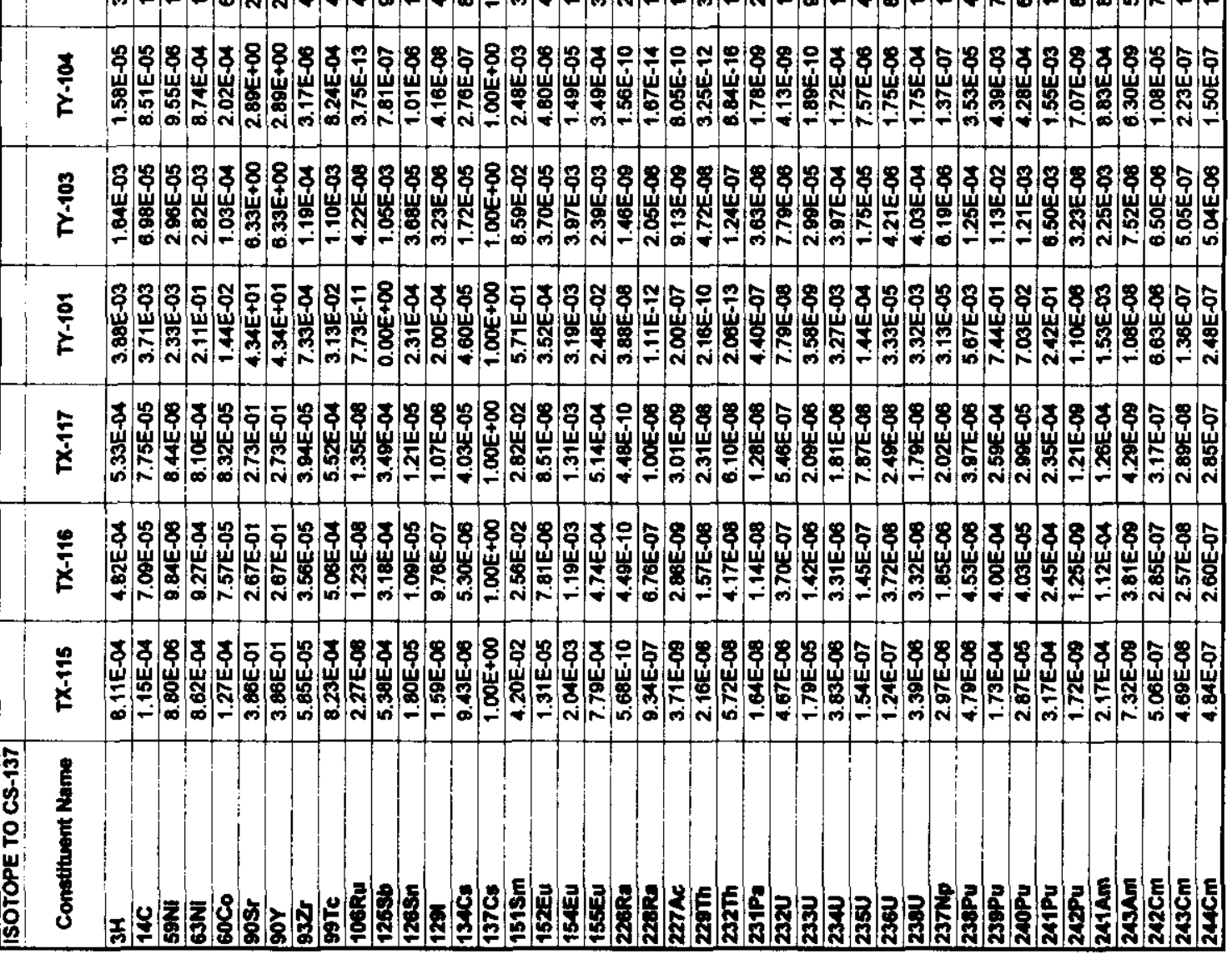


This page intentionally left blank. 
ATTACHMENT D

ANNUAL POSSESSION QUANTITY 
This page intentionally left blank. 


\begin{tabular}{|c|c|c|c|}
\hline $\begin{array}{c}\text { ANNUAL POSSESSION QUANTITY F } \\
\text { NUMBER OF BOREHOLES PER YEAR }\end{array}$ & FOR DRILL & ING & \\
\hline $\begin{array}{l}\text { AVERAGE DEPTH OF CONTANINATED SOIL PER } \\
\text { BOREHOLE (OCCURS AT 10-INCH BOREHOLE } \\
\text { DHANETER) }\end{array}$ & 20 & FEET & \\
\hline $\begin{array}{l}\text { VOLUME OF CONTAMINATED SOHL (20 FEET } \\
\text { LAYER IN 10INCH BOREHOLE) }\end{array}$ & 10.91 & FEET^3 & \\
\hline $\begin{array}{l}\text { MAXIMUM VOLUME OF CONTAMHNATED SOIL } \\
\text { PER BOREHOLE + 15\% EXPANSION }\end{array}$ & 12.54 & FEET^3 & \\
\hline $\begin{array}{l}\text { MAXIMUM VOLUME OF CONTAMINATED SOIL } \\
\text { PER YEAR + 15\% EXPANSION }\end{array}$ & 125.45 & FEET^3 & \\
\hline DENSITY OF SOIL & 97.5 & POUNDSIFEET^3 & $\begin{array}{l}\text { (AVERAGE FOR LOOSE, DRY SAND \& } \\
\text { GRAVEL - MARKS STANDARD } \\
\text { HANDBOOK FOR MECHANICAL } \\
\text { ENGINEERS) }\end{array}$ \\
\hline $\begin{array}{l}\text { TOTAL WEIGHT OF CONTALINATED SOIL PER } \\
\text { YEAR }\end{array}$ & $1.22 E+04$ & POUNDSMEAR & \\
\hline $\begin{array}{l}\text { TOTAL WEIGHT OF CONTANINATED SOIL PER } \\
\text { YEAR }\end{array}$ & $5.55 E+06$ & GRAMSYYEAR & \\
\hline $\begin{array}{l}\text { MAXIMUM AVERACE CE-137 CONCENTRATION } \\
\text { SOIL IN CONTAMINATED LAYER }\end{array}$ & $3.30 E-04$ & $\begin{array}{l}\text { CURIES PER GRAM } \\
\text { OF SOIL }\end{array}$ & \\
\hline ISOTOPE & $\begin{array}{l}\text { AVERAGE } \\
\text { TANK CE-137 } \\
\text { RATIO } \\
\end{array}$ & $\begin{array}{l}\text { AVERAGE CURIES } \\
\text { PER GRAM OF SOIL }\end{array}$ & $\begin{array}{l}\text { TOTAL POSSESSION QUANTITY } \\
\text { CURIES PER YEAR }\end{array}$ \\
\hline $3 \mathbf{H}$ & $4.15 \mathrm{E}-04$ & 1.37E-07 & $7.60 \mathrm{E}-01$ \\
\hline $14 \mathrm{C}$ & $1.15 \mathrm{E}-04$ & 3.79E-08 & 2.11E-01 \\
\hline S9Ni & $2.77 \mathrm{E}-04$ & $9.15 \mathrm{E}-08$ & $5.07 E-01$ \\
\hline 63Ni & $2.70 E-02$ & $8.90 E-06$ & $4.93 E+01$ \\
\hline 60Co & 5.22E-04 & $1.72 \mathrm{E}-07$ & $9.55 E-01$ \\
\hline $90 \mathrm{sr}$ & $1.12 E+01$ & $3.68 E-03$ & $2.04 E+04$ \\
\hline SOY & $1.12 E+01$ & $3.68 \bar{E}-03$ & $2.04 E+04$ \\
\hline $932 r$ & $1.30 E-04$ & $4.29 E-08$ & 2.38E-01 \\
\hline 99Te & 1.92E-03 & 6.34E-07 & $3.52 \mathrm{E}+00$ \\
\hline 10sRu & 9.23E-07 & 3.05E-10 & $1.69 E-03$ \\
\hline $128 \overline{s b}$ & $3.92 E-04$ & $1.29 E-07$ & $7.18 E-01$ \\
\hline $1288 n$ & 4.31E-05 & 1.42E-08 & $7.88 \mathrm{E}-02$ \\
\hline 1291 & 9.28E-06 & 3.06E-09 & $1.70 E-02$ \\
\hline $134 \mathrm{Ce}$ & $7.90 E-06$ & 2.64E-09 & $1.46 \mathrm{E}-02$ \\
\hline $137 \mathrm{Cs}$ & $1.00 \mathrm{E}+00$ & $3.30 E-04$ & $1.83 E+03$ \\
\hline $1518 \mathrm{~m}$ & 1.01E-01 & 3.32E-05 & $1.84 E+02$ \\
\hline 152EU & $2.23 E-04$ & $7.36 E-08$ & 4.08E-01 \\
\hline 154Eu & $4.69 E-03$ & $1.55 \mathrm{E}-06$ & $8.58 E+00$ \\
\hline 156Eu & 1.41E-02 & $4.65 E-06$ & $2.58 E+01$ \\
\hline 228Ra & 1.99E-08 & $6.58 E-12$ & 3.65E-05 \\
\hline 220Ra & 1.04E-08 & 3.42E-10 & 1.90E-03 \\
\hline $2274 \mathrm{c}$ & 2.46E-07 & $8.11 E-11$ & $4.50 E-04$ \\
\hline 229Th & 4.19E-08 & $1.38 \mathrm{E}-11$ & $7.68 \mathrm{E}-05$ \\
\hline 232Th & $4.10 E-08$ & 1.35E-11 & $7.52 E-05$ \\
\hline 231Pa & $2.55 E-07$ & 8.43E-11 & 4.67E-04 \\
\hline $232 U$ & 3.17E-06 & 1.05E-09 & $5.80 E-03$ \\
\hline $233 \mathrm{U}$ & 1.22E-05 & $4.02 E-00$ & 2.23E-02 \\
\hline 2340 & 2.41E-04 & $7.94 E-08$ & $4.40 \mathrm{E}-01$ \\
\hline 2350 & $1.06 E-05$ & $3.51 \mathrm{E}-09$ & $1.95 E-02$ \\
\hline 2384 & $2.46 \mathrm{E}-08$ & 8.11E-10 & $4.50 \mathrm{E}-03$ \\
\hline $238 U$ & $2.42 E-04$ & $8.00 \mathrm{E}-08$ & 4.44E-01 \\
\hline $237 \mathrm{~Np}$ & $1.92 \mathrm{E}-06$ & $6.32 E-10$ & 3.51E-03 \\
\hline $238 \mathrm{Pu}$ & 1.19E-03 & $3.92 E-07$ & 2.17E+00 \\
\hline $239 P \mathrm{u}$ & $1.08 E-01$ & 3.57E-05 & $1.98 E+02$ \\
\hline $240 P u$ & $1.14 \mathrm{E}-02$ & 3.77E-06 & $2.09 E+01$ \\
\hline 241Pu & 6.76E-02 & 2.23E-05 & $1.24 E+02$ \\
\hline 242Pu & $3.23 E-07$ & $1.07 E-10$ & 5.82E-04 \\
\hline $241 \mathrm{Am}$ & 1.88E-02 & 6.21E-08 & $3.44 E+01$ \\
\hline $243 \mathrm{Am}$ & $4.18 E-07$ & $1.38 E-10$ & 7.67E-04 \\
\hline $242 \mathrm{~cm}$ & 1.47E-04 & 4.85E-08 & $2.69 E-01$ \\
\hline $243 \mathrm{Cm}$ & 5.12E-06 & 1.69E-09 & $9.37 \bar{E}-03$ \\
\hline $244 \mathrm{Cm}$ & $4.77 \mathrm{E}-05$ & $1.58 E-08$ & $8.74 E-02$ \\
\hline TOTAL & & & $4.34 E+04$ \\
\hline
\end{tabular}




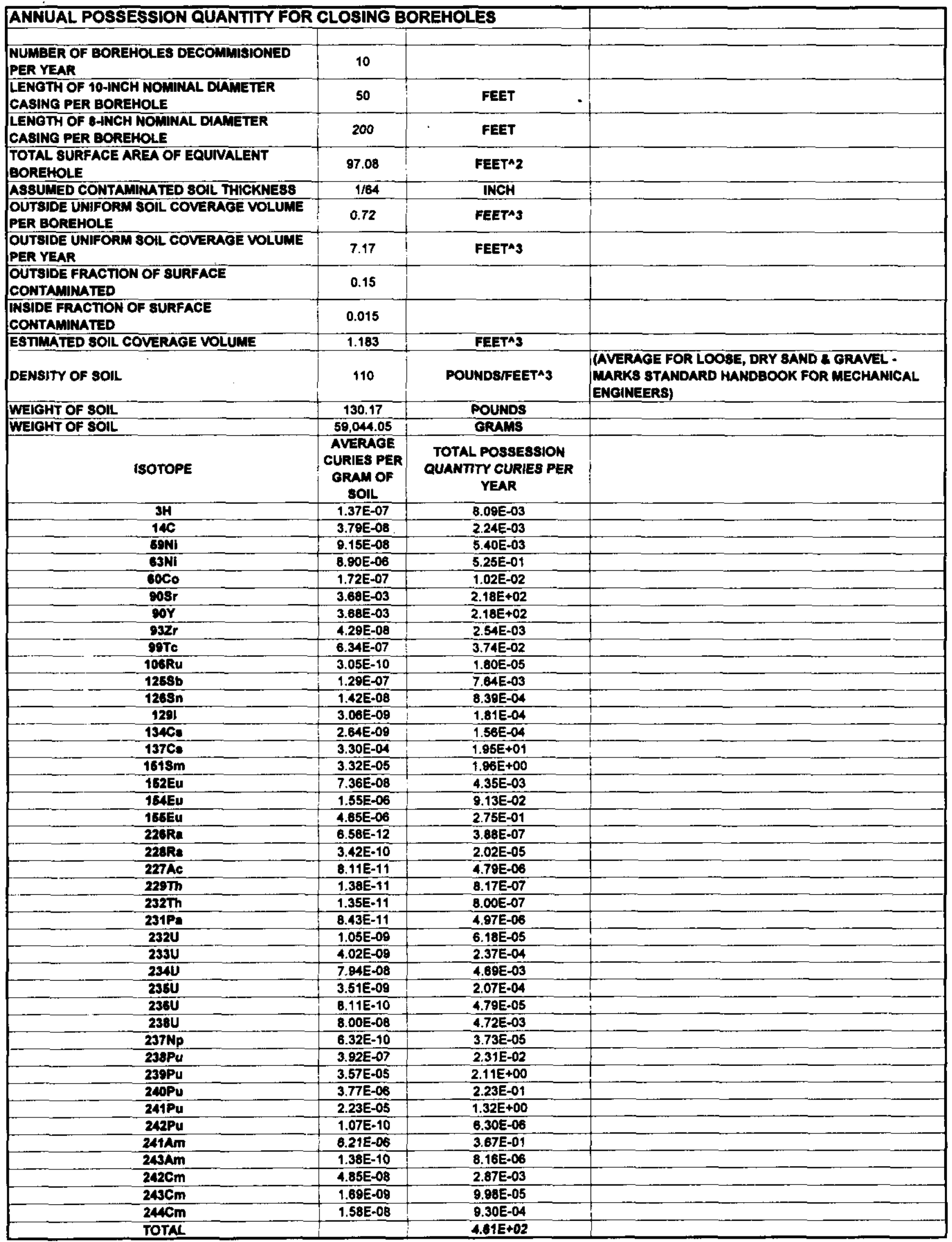




\begin{tabular}{|c|c|c|}
\hline \multicolumn{3}{|c|}{ TOTAL ANNUAL POSSESSION QUANTITY } \\
\hline ISOTOPE & $\begin{array}{l}\text { TOTAL ANNUAL } \\
\text { POSSESSION QUANTITY } \\
\text { CURIES PER YEAR }\end{array}$ & \\
\hline $3 \mathbf{H}$ & $7.68 \mathrm{E}-01$ & \\
\hline $14 \mathrm{C}$ & 2.13E-01 & \\
\hline 59Ni & 5.13E-01 & \\
\hline $63 \mathrm{NI}$ & $4.99 \mathrm{E}+01$ & \\
\hline 60Co & $9.66 \mathrm{E}-01$ & \\
\hline $90 \mathrm{Sr}$ & $2.07 E+04$ & \\
\hline $90 Y$ & $2.07 \mathrm{E}+04$ & \\
\hline $93 \mathbf{r} \mathbf{r}$ & 2.41E-01 & \\
\hline 99Tc & $3.55 \mathrm{E}+00$ & \\
\hline 106Ru & $1.71 \mathrm{E}-03$ & \\
\hline $125 \overline{S b}$ & 7.25E-01 & \\
\hline $1265 n$ & 7.97E-02 & \\
\hline 1291 & $1.72 E-02$ & \\
\hline $134 \mathrm{Cs}$ & $1.48 \mathrm{E}-02$ & \\
\hline 137Cs & $1.85 E+03$ & \\
\hline $151 S m$ & $1.86 E+02$ & \\
\hline 152Eu & 4.13E-01 & \\
\hline 154Eu & $8.67 E+00$ & \\
\hline 155Eu & 2.61E+01 & \\
\hline 226Ra & 3.69E-05 & \\
\hline 228Ra & 1.92E-03 & \\
\hline 227AC & $4.55 E-04$ & \\
\hline 229Th & 7.76E-05 & \\
\hline 232Th & $7.60 E-05$ & \\
\hline 231Pa & 4.72E-04 & \\
\hline $232 \mathrm{U}$ & 5.87E-03 & \\
\hline $233 \mathrm{U}$ & $2.25 \mathrm{E}-02$ & \\
\hline 2340 & 4.45E-01 & \\
\hline $235 \mathrm{U}$ & 1.97E-02 & \\
\hline $236 U$ & $4.55 \mathrm{E}-03$ & \\
\hline $238 U$ & 4.48E-01 & \\
\hline $237 N p$ & 3.55E-03 & \\
\hline 238Pu & $2.20 \mathrm{E}+00$ & \\
\hline 239Pu & $2.00 E+02$ & \\
\hline 240Pu & $2.11 \mathrm{E}+01$ & \\
\hline 241Pu & $1.25 E+02$ & \\
\hline 242Pu & $5.98 \mathrm{E}-04$ & \\
\hline 241Am & $3.48 E+01$ & \\
\hline 243Am & 7.75E-04 & \\
\hline $242 \mathrm{Cm}$ & 2.72E-01 & \\
\hline $243 \mathrm{Cm}$ & 9.47E-03 & \\
\hline $244 \mathrm{Cm}$ & 8.83E-02 & \\
\hline TOTAL & $4.38 \mathrm{E}+04$ & \\
\hline
\end{tabular}


This page intentionally left blank. 
DOE/ORP-2000-05, Rev. 1

$04 / 2000$

ATTACHMENT E

POTENTIAL-TO-EMIT ASSUMPTIONS AND CALCULATIONS

DRILLING BOREHOLES 
This page intentionally left blank. 


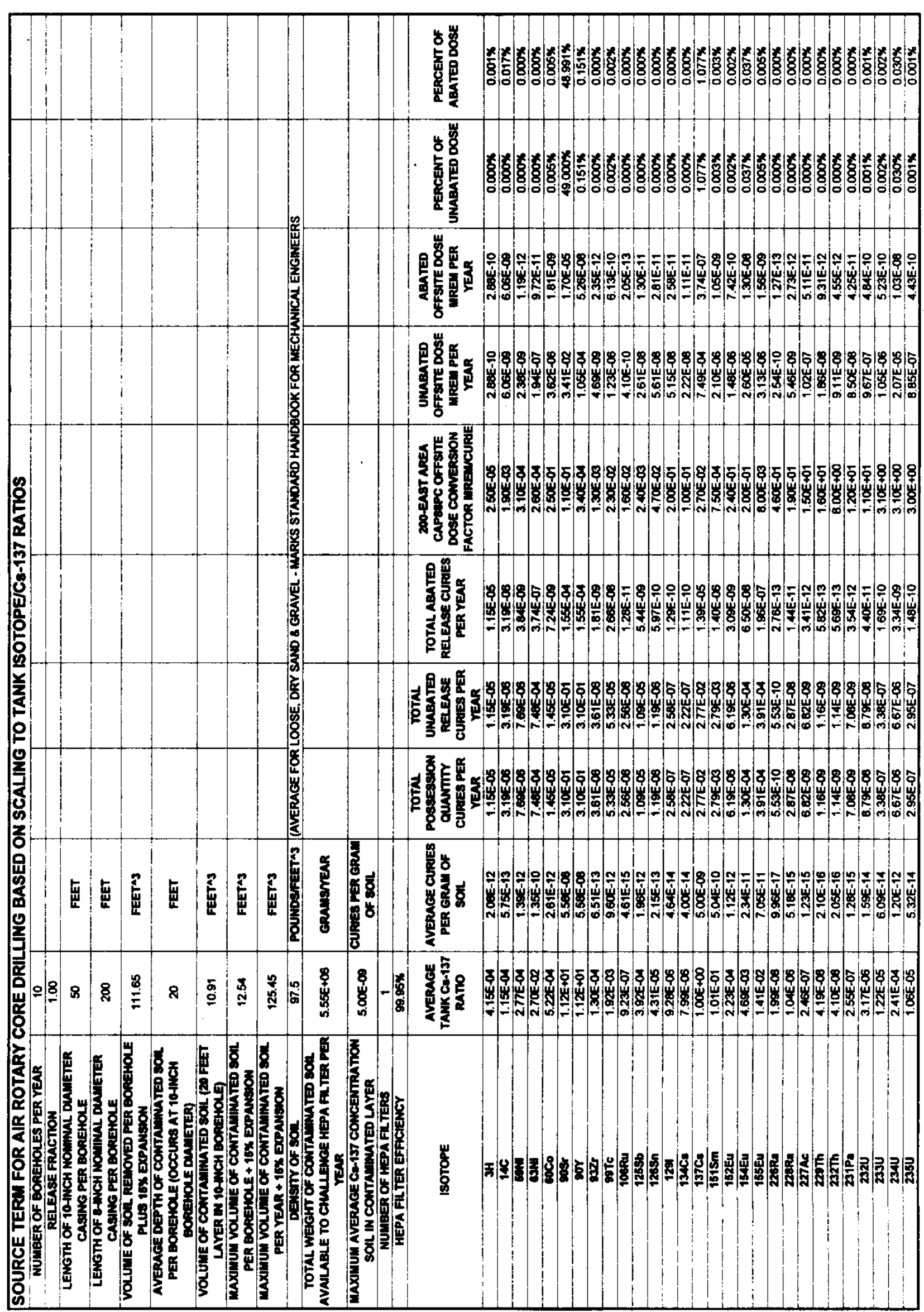



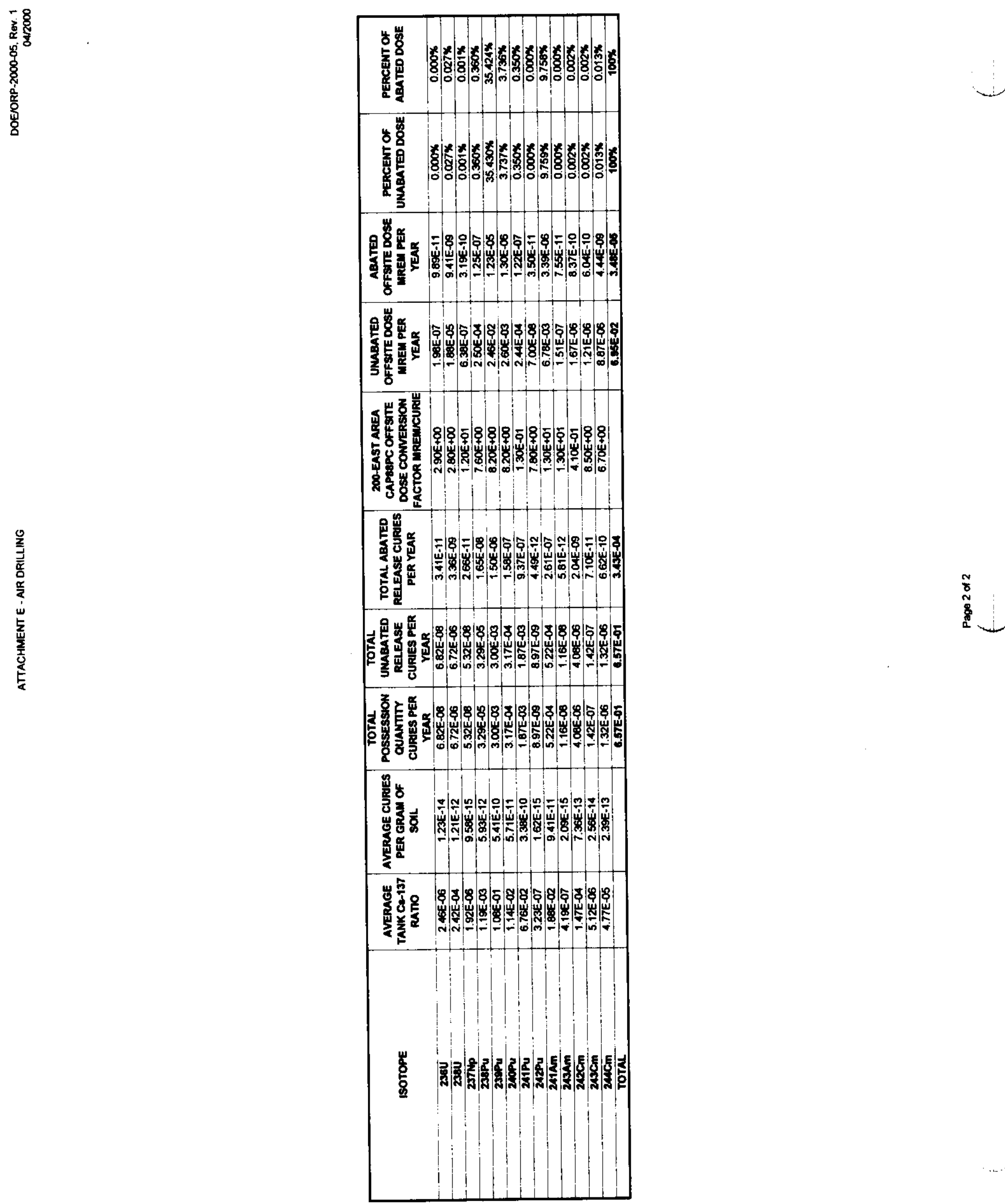


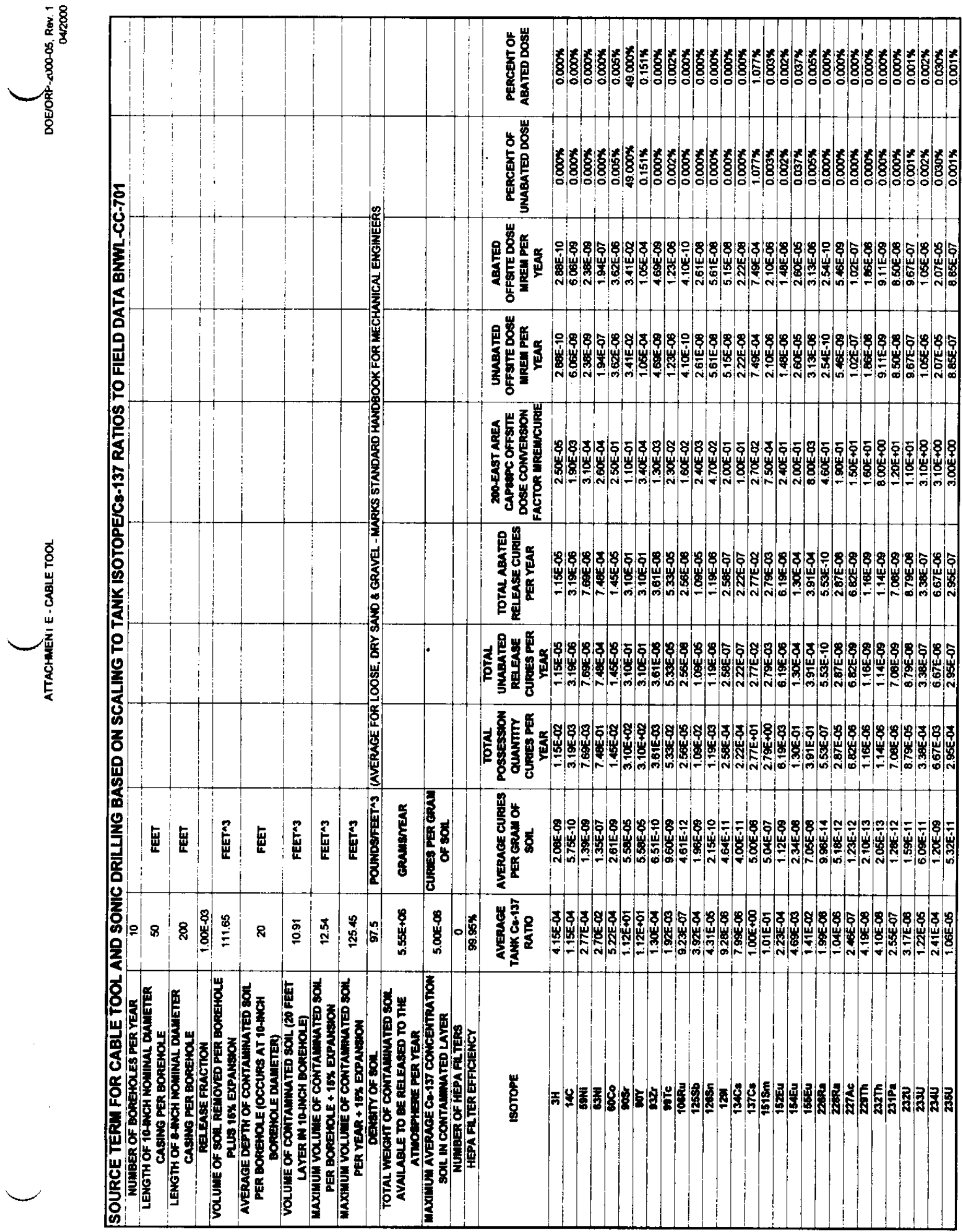




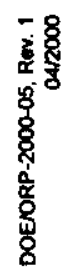

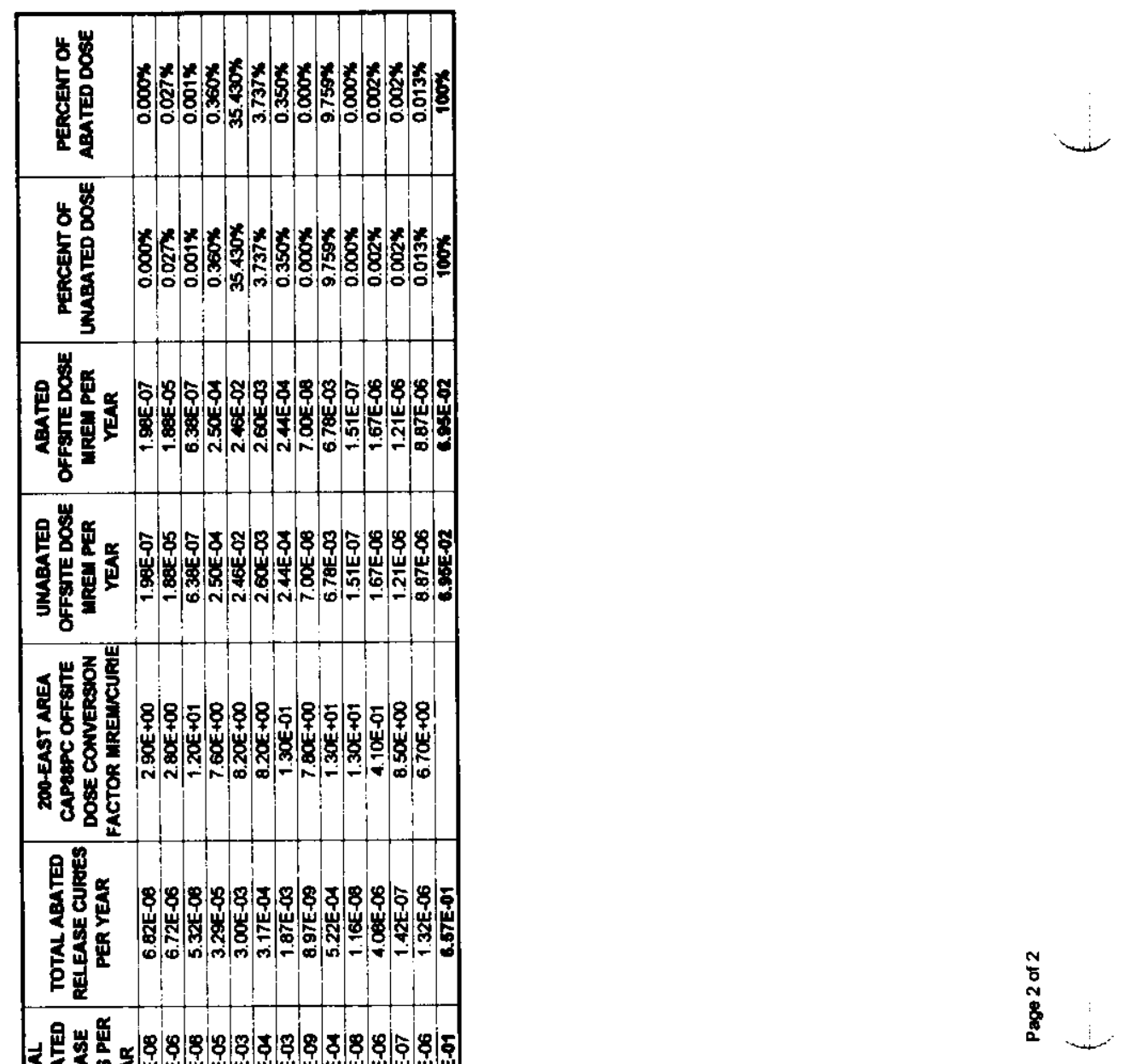

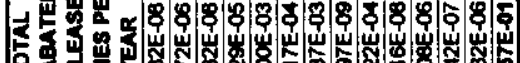

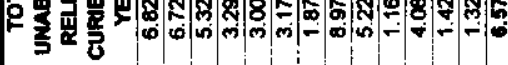

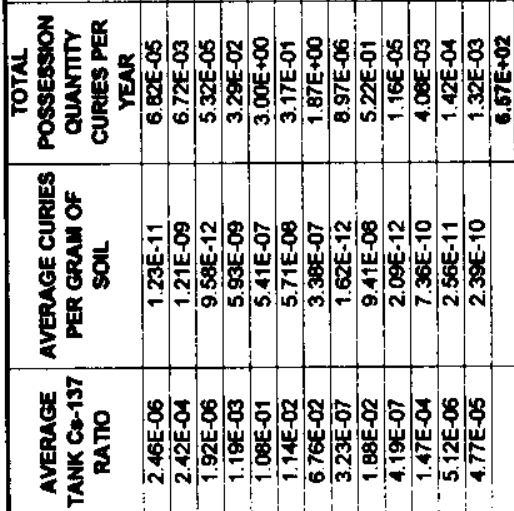

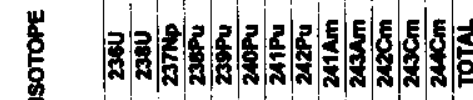




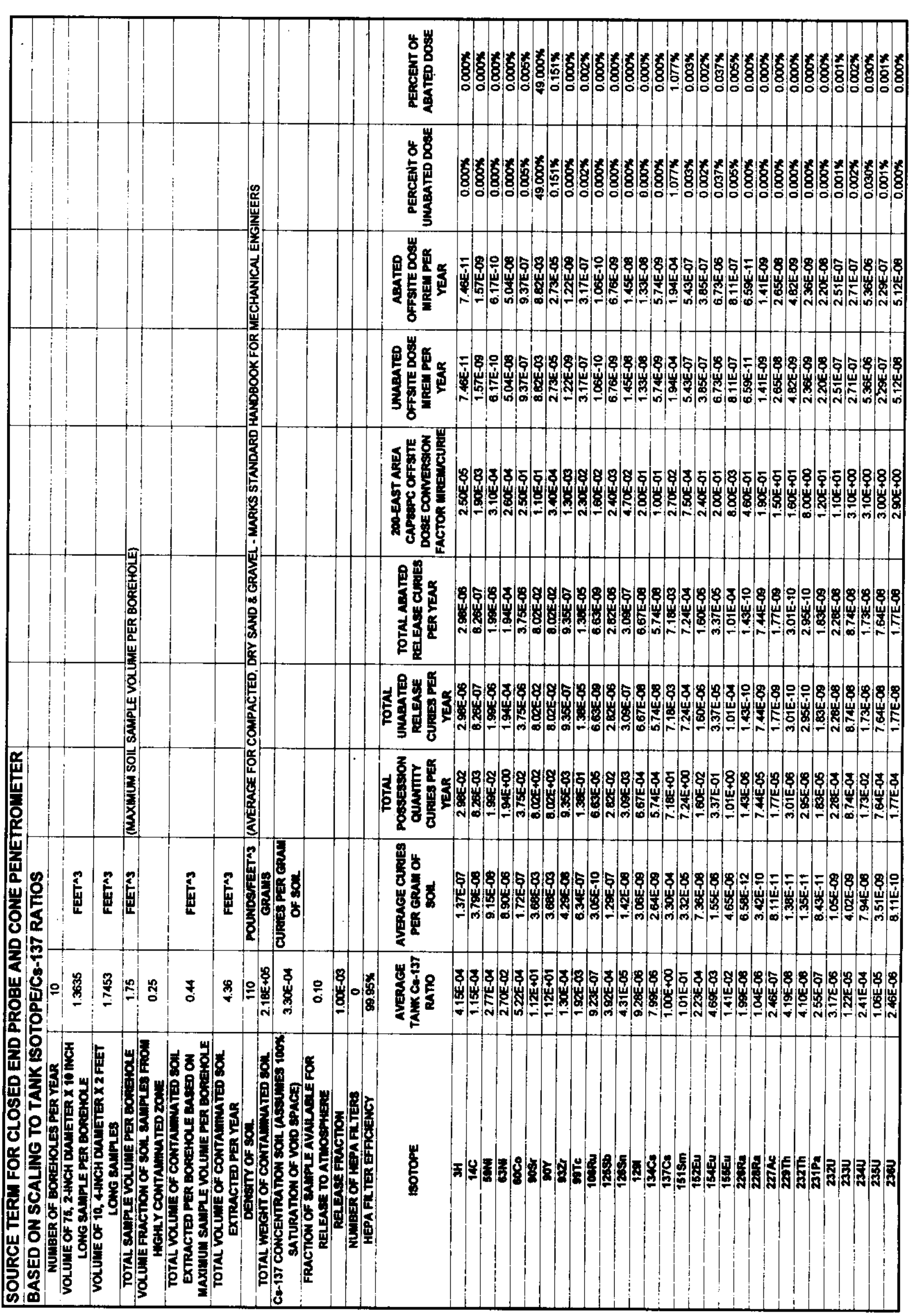




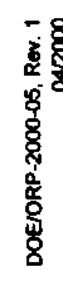

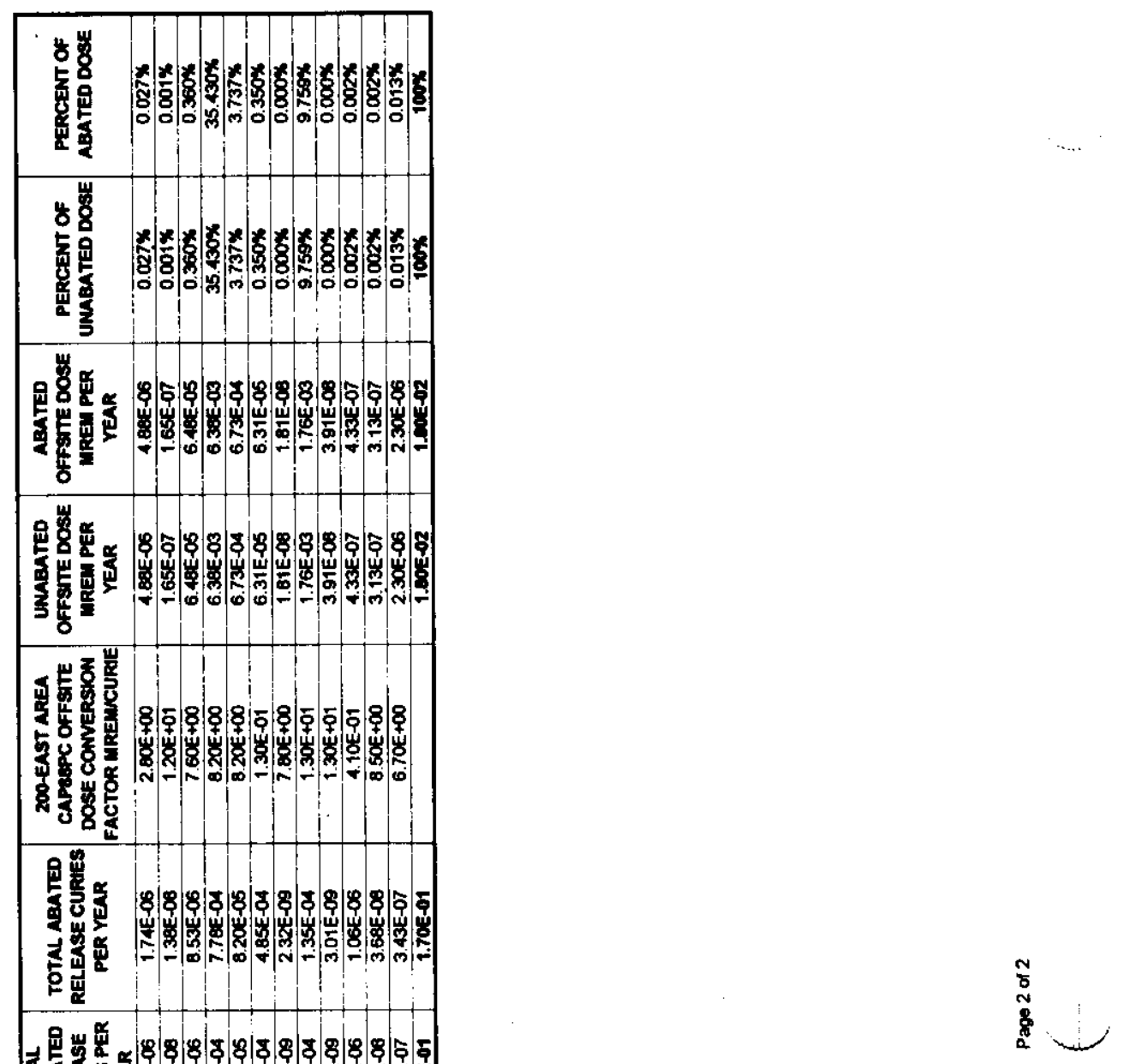

स芭出总

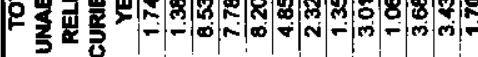

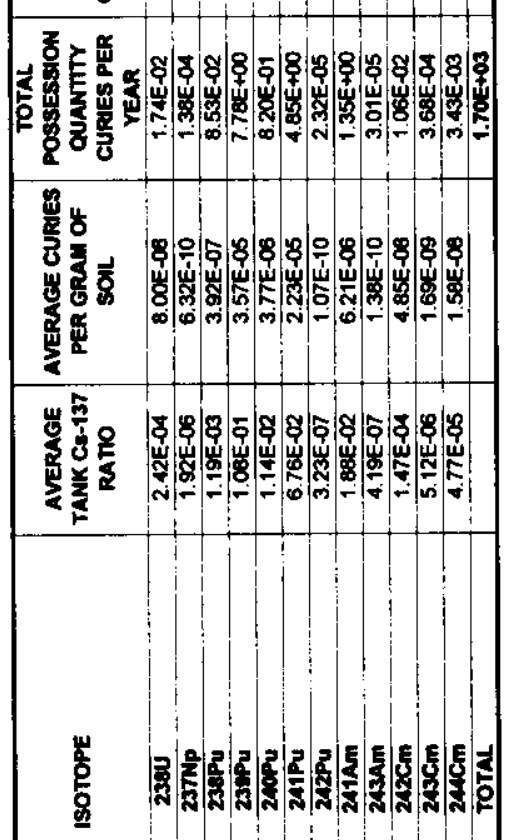




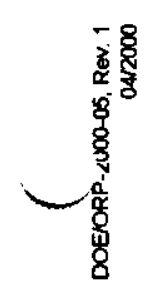

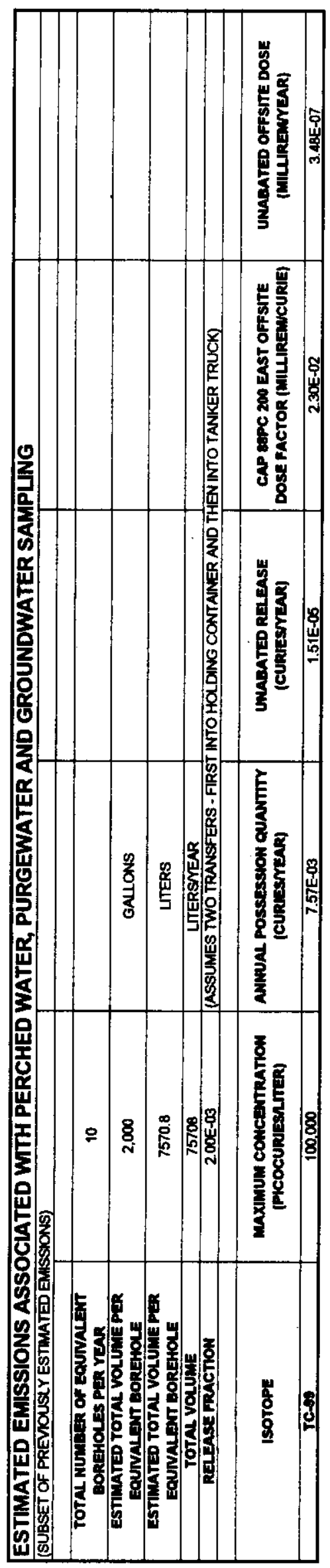

$\overline{8}$ 


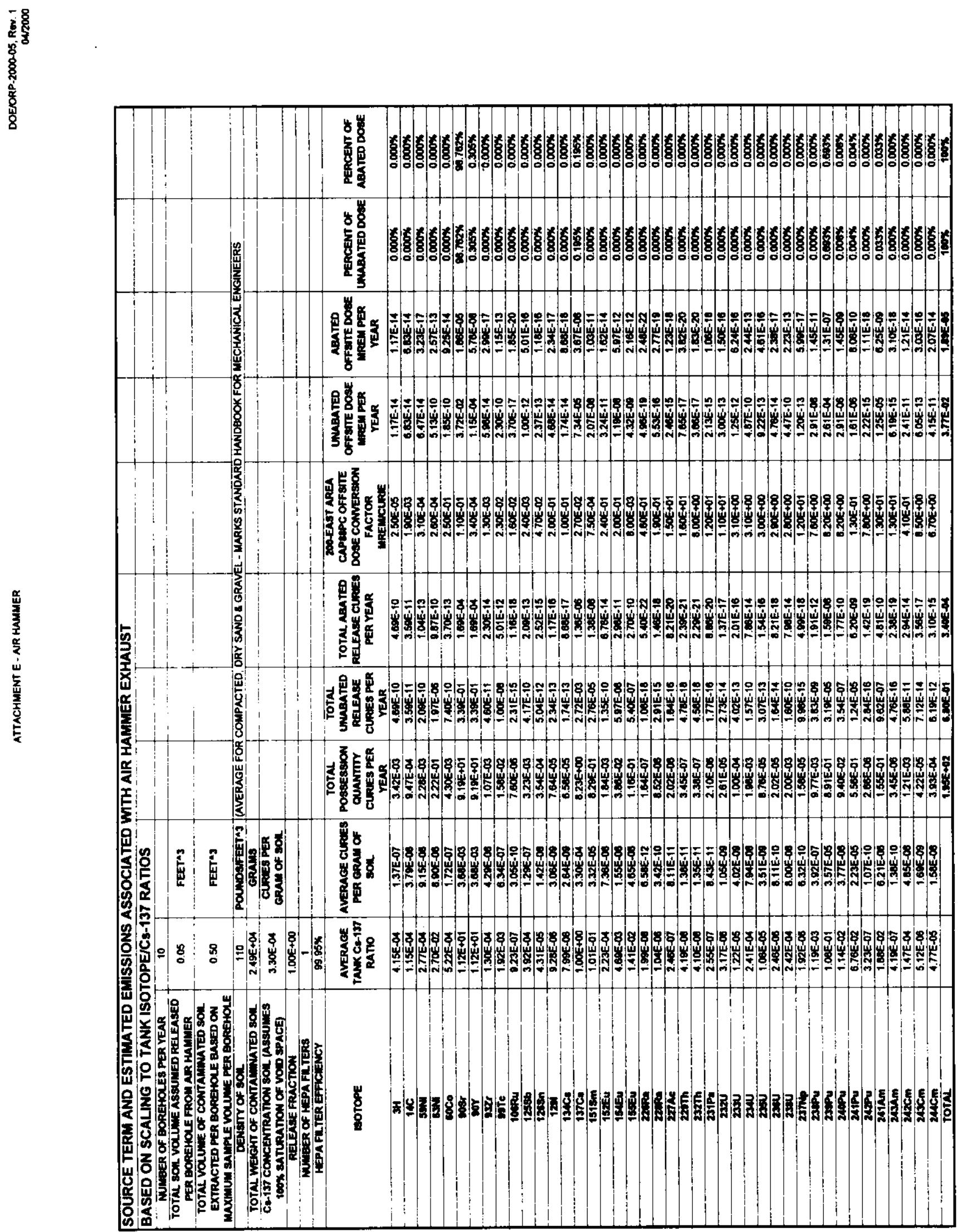


DOE/ORP-2000-05, Rev. 1

$04 / 2000$

\section{ATTACHMENT F}

TWRS ALARACT DEMONSTRATION FOR SOIL EXCAVATION (USING HAND TOOLS) 
This page intentionally left blank. 


\section{ALARACT 5}

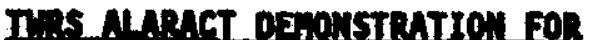

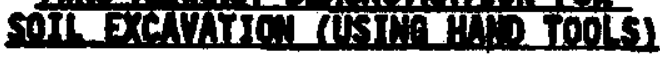

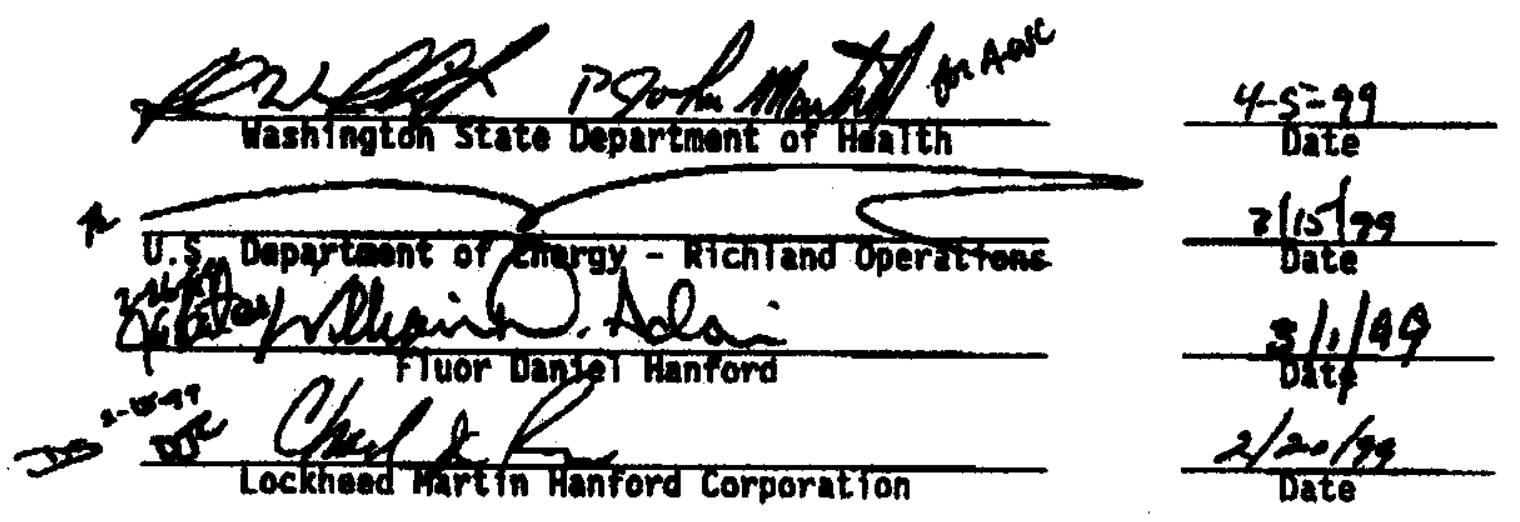

Rev. 0

$2 / 18 / 99$ 
ALARACT 5

HNF-4327, Rev. 0

TWRS ALARACT DEMONSTRATION FOR

SOIL EXCAVATION (USING HAND TOOLS)

1. Description of Activity/Requirements:

Soll is routinely excavated in the TWRS facilities to support riser preparation, repair and maintenance activities, soil sampling, cleanup of contamination, removal of vegetation and biological hazards, and operational activities (laying conduit or cables for power). An initial survey is performed of the area to be excavated. Surveys are performed throughout the excavation to assure that worker safety and environmental protection is maintained. Once the excavation begins, water is used, as necessary, to prevent the spread of dust. To the extent practicable using hand held instrument field survey techniques, the clean soil is separated from the soil identified as contaminated. The contaminated soil has a fixative applied or is covered by plastic at the end of the shift, and as necessary, to stabilize the contaminated soil. The activities covered by this ALARACT demonstration do not include D\&D. All radioactively contaminated soil excavation is conducted using hand tools.

2. Radiological Controls:

- Follow TWRS ALARACT demonstration for "Packaging and Transportation of Waste" (ALARACT 4)

- HPT coverage will be performed as specified in the radiological work permit.

- A beta-gamma survey of the ground surface is required prior to excavation in Contamination Areas ( $\left.C A^{\prime} s\right)$, High Contamination Areas (HCA's), Soil Contamination Areas (SCA's), and Underground Radioactive Material Areas (URMA's). An alpha survey may be required prior to excavation per the "Justification for Dual Survey Exemption in Tank Farm Facilities" HNF-3391.

- For excavation in CA's, HCA's, SCA's, and URMA's, if beta-gamma activity greater than $1000 \mathrm{dpm} / \mathrm{probe}$ area $\left(5000 \mathrm{dpm} / 100 \mathrm{~cm}^{2}\right)$ is identified, alpha surveys will also be performed.

- Suppressants such as water, fixatives, covers, or windscreens will be used as necessary, including at the end of each shift or when sustained or predicted winds are $>20 \mathrm{mph}$.

- If the net alpha for the general area is greater than 140 $\mathrm{dpm} / \mathrm{probe}$ area, $O R$ if the net beta-gamma activity for the general area is greater than $500,000 \mathrm{dpm} /$ probe area, work will be suspended and worker safety evaluated by TWRS Radiological control. Direct contact will also be made to WDOH. After it is determined that there is no threat to worker safety, WDOH has been

Rev. 0 
contacted, and the proper controls (e.g., water fixatives, covers, windscreens) have been put in place, excavation may continue. A contact of WDOH will not be needed if the contamination consists of a hot speck. If hot specks are detected during the radiological:surveys, the specks will be removed and contained before the activity is allowed to continue unless located in the bottom of the trench after excavation has been completed. Specks found in the bottom of the completed trench may be covered with clean fill. A hot speck will be defined as a very small amount (i.e. less than or equal to $100 \mathrm{~cm}^{2}$ ) of contamination reading greater than or equal to 1,000,000 dpm/probe size beta-gamma and/or greater than or equal to $490 \mathrm{dpm} / \mathrm{probe}$ size alpha.

3. Monitoring:

- Radiological surveys (direct surveys of soil)

- Post job survey(s)

4. Records/Documentation:

- Hork package

- Radiological work permit

- Radiologicaj survey report(s)

5. Emission Pathway: $\because$

- Existing passive (fugitive/diffuse)

6. TWRS Facility Descriotion:

A1l TWRS facilities 
DOE/ORP-2000-05, Rev. 1

$04 / 2000$

This page intentionally left blank. 
DOE/ORP-2000-05, Rev. 1

$04 / 2000$

\section{ATTACHMENT G}

SOIL CONTAMINATION STANDARDS FOR PROTECTION FOR PERSONNEL 
This page intentionally left blank. 
WHC-SO-WH-TI-708 Dri

Soil Contanination Standards for Protection of Personnel by Paul D. Rittrann, PhO CHP: May 14, 1997
Fage 1

NOC, Rev. 1

Project W-314

\section{$\cdot 1.0$ Introduction}

- The objective of this report is to recommend soil contamination levels that will ensure that radionuclide intakes by unprotected workers are ilkely to give internal doses below selected dose limits during the working year. The three internal dose 1 fmits are 1, 100, and 500 mrem per year. In addition, photon, beta, and alpha instrument readings are estimated for these soll concentration limits.

Two exposure pathways are considered: the first is inhalation of resuspended dust and the second is ingestion of trace amounts of sol1. In addition, radioactive decay and ingrowth of progeny during the year of exposure is included. External dose from the soli contanination is not included because r.onitoring and control of external exposures is carried out independentiy from internal exposuras, which are the focus of this report. The methods used are sinilar to those used by Carbaugh and Bihl (1993) to set bioassy criteria for such workers.

\subsection{Summary of Methods}

The inhalation dose from resuspended dust is calculated using a mass foading approach. The air breathed by the worker is assumed to have an average dust loading of $5 \mathrm{mg} / \mathrm{m}^{3}$ of respirable sized particles, 1.e., less than 10 H AHAD. The worker is assumed to breathe this dust for 2000 hours at the light activity breathing rate for reference man (ICRP 1975), $1.2 \mathrm{~m}^{2}$ /hour. The total amount of dust inhaled is therefore 12. grams over the course of the year. It is assuned that the radionuclide concentration in the airborne dust is the sare as it is in the contaminated soil. Technically, this is incorrect. The soil. contanination is normally found in the soil fines so that the radionuclide concentration in the airborne dust is far greater than in the bulk soil. However, the assumed average air concentration of $5 \mathrm{mg} / \mathrm{m}^{3}$ is also very large. It is the OSHA linit for workplace dust. In addition, the assuned exposure time of 2000 hours per year at this high concentration also leads to large intakes. Therefore, it will be assumed that the above combination of assumptions represent a reasonable worst case inhalation model.:

The ingestion dose from eating trace amounts of soll is based on the EPA soll ingestion value of $100 \mathrm{mg} / \mathrm{day}$ for adults. The ingestion takes place through licking the lips and similar motions. The worker is assuned to consume soil at this rate for 250 days during the year. The total amount ingested in $a$ year is therefore 25 grams of soil.

f.ppendix A suminarizes the date used in these calculations: The 128 distinct radionuclides have half-lfves greater than 33 days. Implicit daughters shown in Table A-2 have been included in the calculations of dose. It is assumed that these short-lived nuclides are in secular equilibrium with the parent at all times. The radioactive decay information is from Kocher (1981). This was used to determine the relative amounts of the short-lived progeny, as well as the decay and ingrowth of longer-lived progeny during the year of exposure. The specific decay chains used during the year of exposure are listed in. Table $A-1$. 
Page $5 \quad r$

NOC. Rev.

Project W-314

Table 1. Unit Dose Factors and Soll Concentration Limits

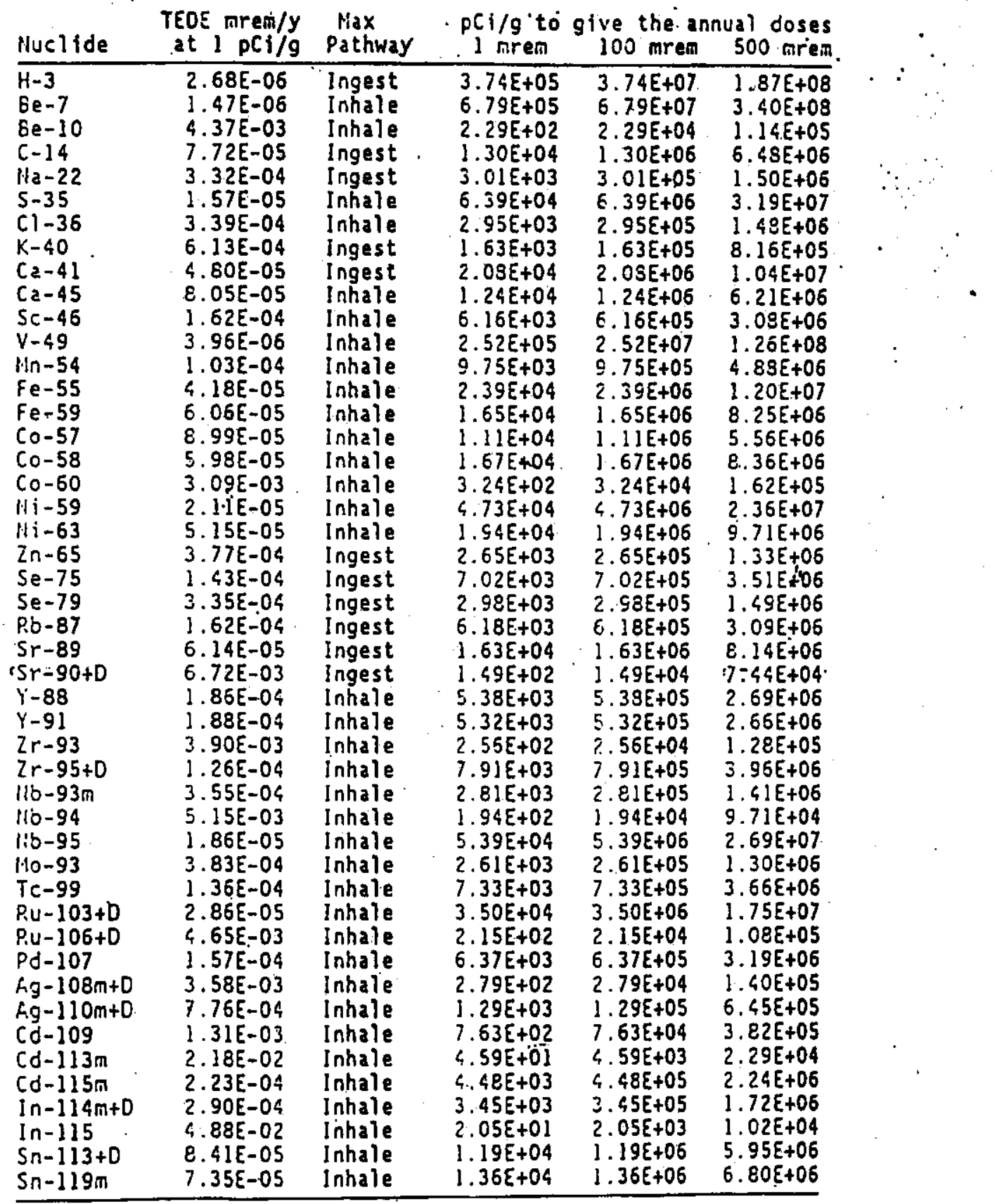


Page 7

NOC, Revi. 1

Project.W.314

Table 1. Unit Dose Factors and Soll Concentration Limits, Continued

TEOE mrem/y Max. PCi/g to give the annual doses

\begin{tabular}{|c|c|c|c|c|c|}
\hline llucl tode & at $1 \mathrm{pCl} / 9$ & $\begin{array}{l}\text { Max } \\
\text { Pathway }\end{array}$ & $\begin{array}{c}\mathrm{PCi} / \mathrm{g} \text { to } \\
1 \text { mren }\end{array}$ & 100 mren & 500 mrem \\
\hline 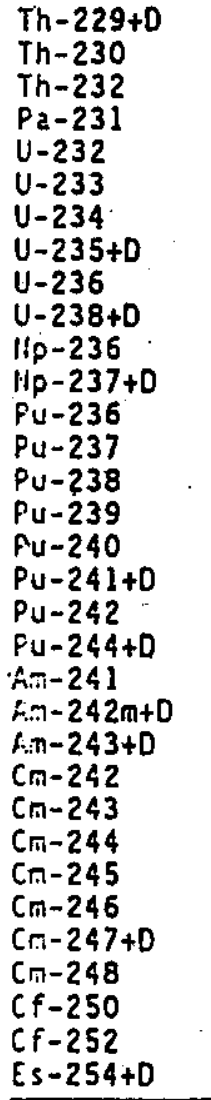 & $\begin{array}{l}2.61 E+01 \\
3.92 E+00 \\
1.98 E+01 \\
1.69 E+01 \\
6.78 E-01 \\
1.04 E-01 \\
1.02 E-01 \\
9.43 E-02 \\
9.60 E-02 \\
9.14 E-02 \\
1.29 E+00 \\
6.59 E+00 \\
1.57 E+00 \\
6.50 E-06 \\
4.77 E+00 \\
5.24 E+00 \\
5.24 E+00 \\
1.03 E-01 \\
5.01 E+00 \\
4.92 E+00 \\
5.41 E+00 \\
5.27 E+00 \\
5.37 E+00 \\
1.19 E-01 \\
3.70 E+00 \\
2.97 E+00 \\
5.56 E+00 \\
5.51 E+00 \\
5.06 E+00 \\
2.02 E+01 \\
3.11 E+00 \\
1.68 E+00 \\
3.90 E-01\end{array}$ & $\begin{array}{l}\text { Inhale } \\
\text { Inhale } \\
\text { Inhale } \\
\text { Inhale } \\
\text { Inhale } \\
\text { Inhale } \\
\text { Inhale } \\
\text { Inhale } \\
\text { Inhale } \\
\text { Inhale } \\
\text { Inhale } \\
\text { Inhale } \\
\text { Inhale } \\
\text { Inhale } \\
\text { Inhale } \\
\text { Inhale } \\
\text { Inhale } \\
\text { Inhale } \\
\text { Inhale } \\
\text { Inhale } \\
\text { Inhale } \\
\text { Inhale } \\
\text { Inhale } \\
\text { Inhale } \\
\text { Inhale } \\
\text { Inhale } \\
\text { Inhale } \\
\text { Inhale } \\
\text { Inhale } \\
\text { Inhale } \\
\text { Inhale } \\
\text { Inhale } \\
\text { Inhale }\end{array}$ & $\begin{array}{l}3.83 E-02 \\
2.55 E-01 \\
5.05 E-02 \\
5.90 E-02 \\
1.14 E+00 \\
9.58 E+00 \\
9.84 E+00 \\
1.06 E+01 \\
1.04 E+01 \\
1.09 E+01 \\
7.77 E-01 \\
1.52 E-01 \\
6.37 E-01 \\
1.54 E+05 \\
2.10 E-01 \\
1.91 E-01 \\
1.91 E-01 \\
9.75 E+00 \\
2.00 E-01 \\
2.03 E-01 \\
1.85 E-01 \\
1.90 E-01 \\
1.85 E-01 \\
8.43 E+00 \\
2.70 E-01 \\
3.37 E-01 \\
1.80 E-01 \\
1.82 E-01 \\
1.98 E-01 \\
6.95 E-02 \\
3.21 E-01 \\
5.95 E-01 \\
2.56 E+00\end{array}$ & $\begin{array}{l}3.83 E+00 \\
2.55 E+01 \\
5.06 E+00 \\
5.90 E+00 \\
1.14 E+02 \\
9.58 E+02 \\
9.84 E+02 \\
1.06 E+03 \\
1.04 E+03 \\
1.09 E+03 \\
7.77 E+01 \\
1.52 E+01 \\
6.37 E+01 \\
1.54 E+07 \\
2.10 E+01 \\
1.91 E+01 \\
1.91 E+01 \\
9.75 E+02 \\
2.00 E+01 \\
2.03 E+01 \\
1.85 E+01 \\
1.90 E+01 \\
1 . E 5 E+01 \\
8.43 E+02 \\
2.70 E+01 \\
3.37 E+01 \\
1.80 E+01 \\
1.82 E+01 \\
1.93 E+01 \\
4.95 E+00 \\
3.21 E+01 \\
5.95 E+01 \\
2.56 E+02\end{array}$ & $\begin{array}{l}1.92 E+01 \\
1.28 E+02 \\
2.53 E+01 \\
2.95 E+01 \\
5.69 E+02 \\
4.79 E+03 \\
4.92 E+03 \\
5.30 E+03 \\
5.21 E+03 \\
5.47 E+03 \\
3.88 E+02 \\
7.58 E+01 \\
3.18 E+02 \\
7.70 E+07 \\
1.05 E+02 \\
9.54 E+01 \\
9.54 E+01 \\
4.87 E+03 \\
9.98 E+01 \\
1.02 E+02 \\
9.23 E+01 \\
9.48 E+01 \\
9.30 E+01 \\
4.21 E+03 \\
1.35 E+02 \\
1.68 E+02 \\
9.01 E+01 \\
9.03 E+01 \\
9.88 E+01 \\
2.48 E+01 \\
1.61 E+02 \\
2.92 E+02 \\
1.28 E+03\end{array}$ \\
\hline $\begin{array}{ll}2 r-95 & \text { old } \\
5 b-125 & \text { old } \\
\text { fb-210 old } \\
\text { F.a-226 old } \\
\text { Th-11at } \\
U-11 a t \\
\text { Pu } 6 \% \\
\text { Fu } 6 \% & 10 y r \\
U-232 & Y \\
U-233 & Y \\
U-234 & Y \\
U-235+D & Y \\
U-236 & Y \\
U-238+D & Y\end{array}$ & $\begin{array}{l}1.67 E-04 \\
2.31 E-04 \\
4.55 E-01 \\
6.03 E-01 \\
2.50 E+01 \\
4.71 E+00 \\
5.95 E+00 \\
5.65 E+00 \\
8.57 E+00 \\
1.63 E+00 \\
1.60 E+00 \\
1.48 E+00 \\
1.51 E+00 . \\
1.43 E+00 .\end{array}$ & $\begin{array}{l}\text { Inhale } \\
\text { Inhale } \\
\text { Inhale } \\
\text { Inhale } \\
\text { Inhale } \\
\text { Inhale } \\
\text { Inhale } \\
\text { Inhale } \\
\text { Inhale } \\
\text { Inhale } \\
\text { Inhale } \\
\text { Inhale } \\
\text { Inhale } \\
\text { Inhale }\end{array}$ & $\begin{array}{l}5.97 E+03 \\
4.34 E+03 \\
2.20 E+00 \\
1.66 E+00 \\
4.17 E-02 \\
2.12 E-01 \\
1.68 E-01 \\
1.77 E-01 \\
1.17 E-01 \\
6.12 E-01 \\
6.26 E-01 \\
6.75 E-01 \\
6.62 E-01 \\
7.01 E-01\end{array}$ & $\begin{array}{l}5.97 E+05 \\
4.34 E+05 \\
2.20 E+02 \\
1.66 E+02 . \\
4.17 E+00 \\
2.1 .2 E+01 \\
1.68 E+01 \\
1.77 E+01 \\
1.17 E+01 \\
6.12 E+01 \\
6.26 E+01 \\
6.75 E+01 \\
6.62 E+01 \\
7.01 E+01\end{array}$ & $\begin{array}{l}9 E+06 \\
17 E+06 \\
0 E+03 \\
30 E+02 \\
8 E+01 \\
96 E+02 \\
1 E+01 \\
4 E+01 \\
4 E+01 \\
5 E+02 \\
3 E+02 \\
18 E+02 \\
1 E+02 \\
0 E+02\end{array}$ \\
\hline
\end{tabular}

lote: See discussion in Section 3.0 for explanation of table. 
Page 14:

NOC, Rev,

Project W-3is

Table 4. Soll Limits and Instrument fiesponse - $500 \mathrm{mrem} / \mathrm{y}$

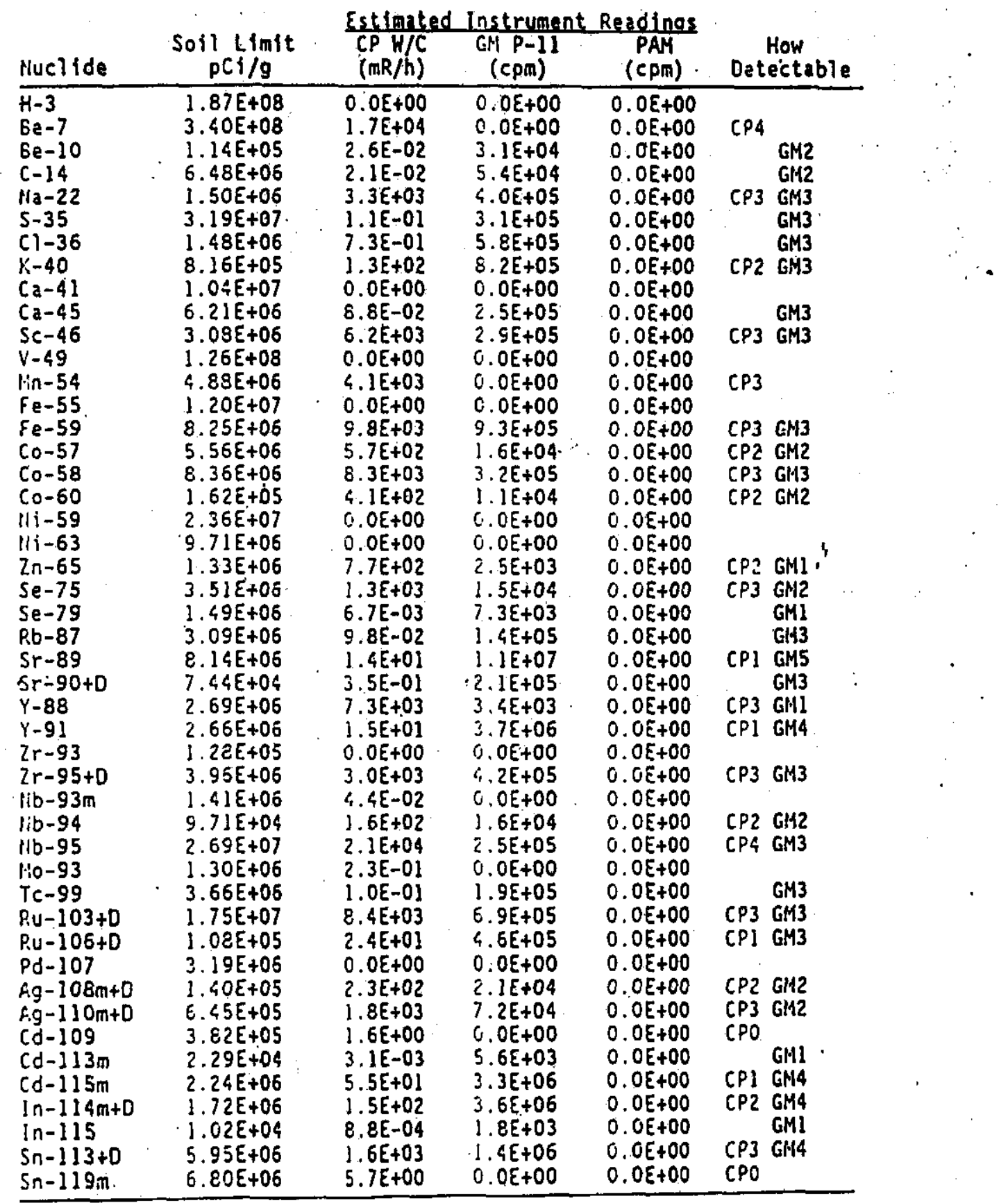


DOE/ORP-2000-05, Rev. 1

$04 / 2000$

KHC-5D-KIY-TI-703 Orz

Page 16

NOC, Rev.

. Project W-314

Table 4. Soil Limits and instrument Resporse - $500 \mathrm{mrem} / \mathrm{y}$, Continued

\begin{tabular}{|c|c|c|c|c|c|c|c|}
\hline Nuclide & $\begin{array}{c}\text { Soll } L\{m i t \\
\mathrm{pCi} / \mathrm{g}\end{array}$ & $\begin{array}{l}\frac{\text { Estimat }}{C P K / C} \\
(m R / h)\end{array}$ & $\begin{array}{c}\text { Instrume } \\
\text { GA P-11 } \\
\text { (cpri) }\end{array}$ & 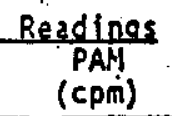 & & & \\
\hline 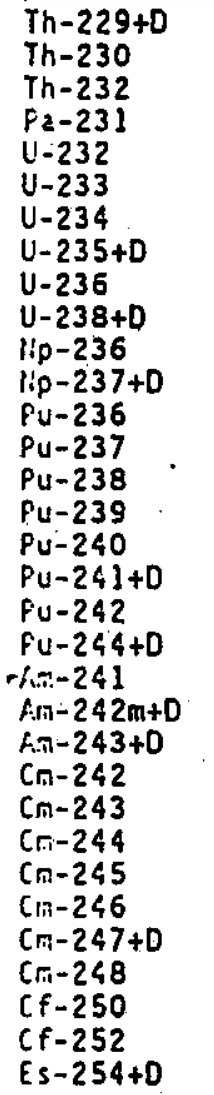 & $\begin{array}{l}1.92 E+01 \\
1.28 E+02 \\
2.53 E+01 \\
2.95 E+01 \\
5.69 E+02 \\
4.79 E+03 \\
4.92 E+03 \\
5.30 E+03 \\
5.21 E+03 \\
5.47 E+03 \\
3.83 E+02 \\
7.58 E+01 \\
3.18 E+02 \\
7.70 E+07 \\
1.05 E+02 \\
9.54 E+01 \\
9.54 E+01 \\
4.87 E+03 \\
9.98 E+01 \\
1.02 E+02 \\
9.23 E+01 \\
9.48 E+01 \\
9.30 E+01 \\
4.21 E+03 \\
1.35 E+02 \\
1.68 E+02 \\
9.00 E+01 \\
9.03 E+01 \\
9.88 E+01 \\
2.48 E+01 \\
1.61 E+02 \\
2.98 E+02 \\
1.28 E+03\end{array}$ & $\begin{array}{l}5.7 E-03 \\
3.3 E-05 \\
2.9 E-06 \\
1.1 E-03 \\
1.1 E-04 \\
1.4 E-03 \\
4.4 E-04 \\
7.9 E-01 \\
2.6 E-04 \\
1.3 E-01 \\
3.7 E-02 \\
1.6 E-02 \\
1.8 E-05 \\
2.6 E+03 \\
4.1 E-05 \\
5.6 E-06 \\
3.4 E-06 \\
1.9 E-05 \\
3.3 E-06 \\
3.5 E-02 \\
9.5 E-04 \\
1.3 E-03 \\
1.7 E-02 \\
1.9 E-04 \\
1.6 E-02 \\
5.6 E-06 \\
6.3 E-03 \\
3.0 E-06 \\
3.4 E-02 \\
5.7 E-07 \\
4.5 E-06 \\
1.3 E-05 \\
1.1 E+00\end{array}$ & $\begin{array}{l}2.6 E+01 \\
0.0 E+00 \\
1.4 E-03 \\
2.1 E-01 \\
5.5 E-02 \\
4.8 E-02 \\
2.9 E-01 \\
2.7 E+02 \\
2.3 E-01 \\
1.2 E+04 \\
3.0 E+01 \\
1.2 E+01 \\
0.0 E+00 \\
1.2 E+03 \\
0.0 E+00 . \\
0.0 E+00 \\
0.0 E+00 \\
6.3 E-03 \\
0.0 E+00 \\
1.6 E+02 \\
6.0 E-03 \\
2.1 E+01 \\
1.7 E+01 \\
0.0 E+00 \\
1.0 E+01 \\
0.0 E+00 \\
2.4 E+00 \\
6.0 E+00 \\
2.1 E+01 \\
6.0 E+00 \\
7.2 E-04 \\
1.9 E-03 \\
6.4 E+02 \\
\end{array}$ & $\begin{array}{l}1.0 E+01 \\
5.7 E+00 \\
6.5 E-01 \\
1.7 E+00 \\
3.7 E+01 \\
2.4 E+02 \\
2.4 E+02 \\
1.9 E+02 \\
2.0 E+02 \\
1.7 E+02 \\
0.0 E+00 \\
3.6 E+00 \\
2.5 E+01 \\
0.0 E+00 \\
7.4 E+00 \\
5.7 E+00 \\
5.7 E+00 \\
0.0 E+00 \\
5.2 E+00 \\
4.3 E+00 \\
.6 .5 E+00 \\
2.8 E-02 \\
5.9 E+00 \\
3.9 E+02 \\
1.1 E+01 \\
1.4 E+01 \\
6.0 E+00 \\
6.1 E+00 \\
5.3 E+00 \\
1.3 E+00 \\
1.4 E+01 \\
2.7 E+01 \\
1.3 E+02\end{array}$ & CP3 & $\begin{array}{l}\text { GNO } \\
\text { GN2 } \\
\text { GMI }\end{array}$ & $\begin{array}{l}\text { PAMO } \\
\text { PAMO } \\
\text { PAMO } \\
\text { PAMO } \\
2 \text { PAMO }\end{array}$ \\
\hline $\begin{array}{ll}2 r-9.5 & \text { old } \\
\text { Sb-125 old } \\
\text { Fb-210 old } \\
\text { F.-226 old } \\
\text { Th-11at } \\
U-11 a t \\
\text { Fu } 6 \% \\
\text { Pu } 6 \% & \\
U-232 & Y y r \\
U-233 & Y \\
U-234 & Y \\
U-235+D & Y \\
U-236 & Y \\
U-238+D Y\end{array}$ & $\begin{array}{l}2.99 E+06 \\
2.17 E+06 \\
1.10 E+03 \\
8.30 E+02 \\
2.03 E+01 \\
1.06 E+02 \\
8.41 E+01 \\
.8 .84 E+01 \\
5 . E 5 E+01 \\
3.05 E+02 \\
3.1 .3 E+02 \\
3.38 E+02 \\
3.31 E+02 \\
3.50 E+02\end{array}$ & $\begin{array}{l}7.4 E+03 \\
9.3 E+02 \\
1.4 E-03 \\
1.5 E+00 \\
5.3 E-02 \\
1.9 E-01 \\
6.3 E-05 \\
1.4 E-04 \\
1.1 E-05 \\
8.8 E-05 \\
2.8 E-05 \\
5.0 E-02 \\
1.6 E-05 \\
\varepsilon .4 E-03\end{array}$ & $\begin{array}{l}3.8 E+05 \\
1.8 E+05 \\
8.6 E+02 \\
2.4 E+03 \\
5.6 E+01 \\
5.4 E+02 \\
1.4 E-03 \\
1.2 E-03 \\
5.6 E-03 \\
3.1 E-03 \\
1.8 E-02 \\
1.7 E+01 \\
1.5 E-02 \\
7.8 E+02\end{array}$ & $\begin{array}{l}0.0 E+00 \\
0.0 E+00 \\
7.2 E+01 \\
3.5 E+02 \\
1.1 E+01 \\
5.8 E+01 \\
5.1 E+00 \\
5.5 E+00 . \\
3.8 E+00 \\
1.5 E+01 \\
1.5 E+01 \\
1.2 E+01 \\
1.3 E+01 \\
1.1 E+01\end{array}$ & $\begin{array}{l}\text { CP3 } \\
\text { CP2 } \\
\text { CPO }\end{array}$ & $\begin{array}{l}\text { GM3 } \\
\text { GH3 } \\
\text { GMO } \\
\text { GH1 } \\
\text { GHO }\end{array}$ & PAMO \\
\hline
\end{tabular}


This page intentionally left blank. 
DOE/ORP-2000-05, Rev. 1

$04 / 2000$

\section{ATTACHMENT H}

ANNUAL POSSESSION QUANTITY AND POTENTIAL TO EMIT FOR

EXCAVATION ACTIVITIES 
This page intentionally left blank. 

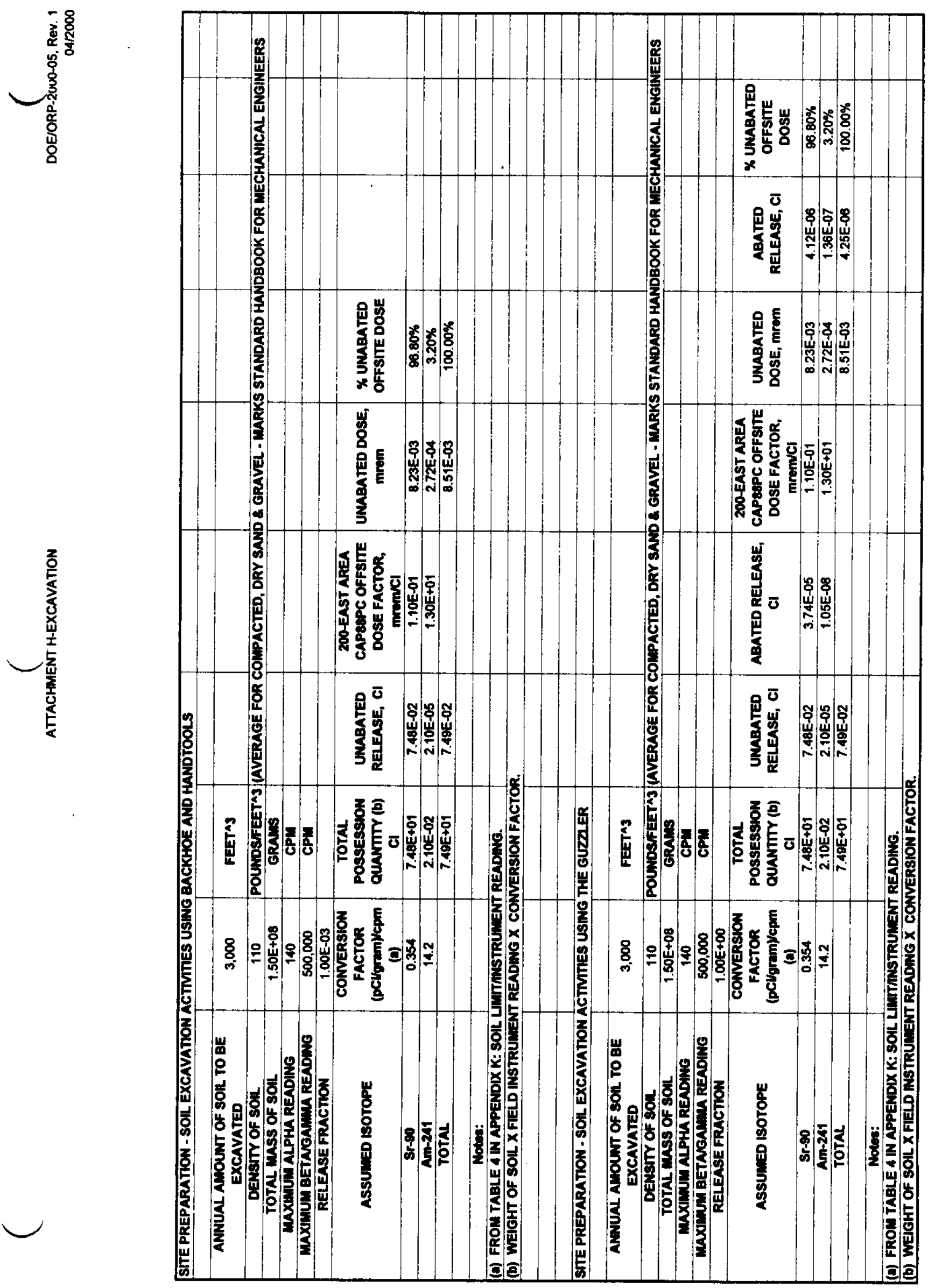
DOE/ORP-2000-05, Rev. 1

04/2000

This page intentionally left blank. 


\section{ATTACHMENT I}

POTENTIAL-TO-EMIT ASSUMPTIONS AND CALCULATIONS

CLOSING BOREHOLES AND REMOVING CASING 
This page intentionally left blank. 


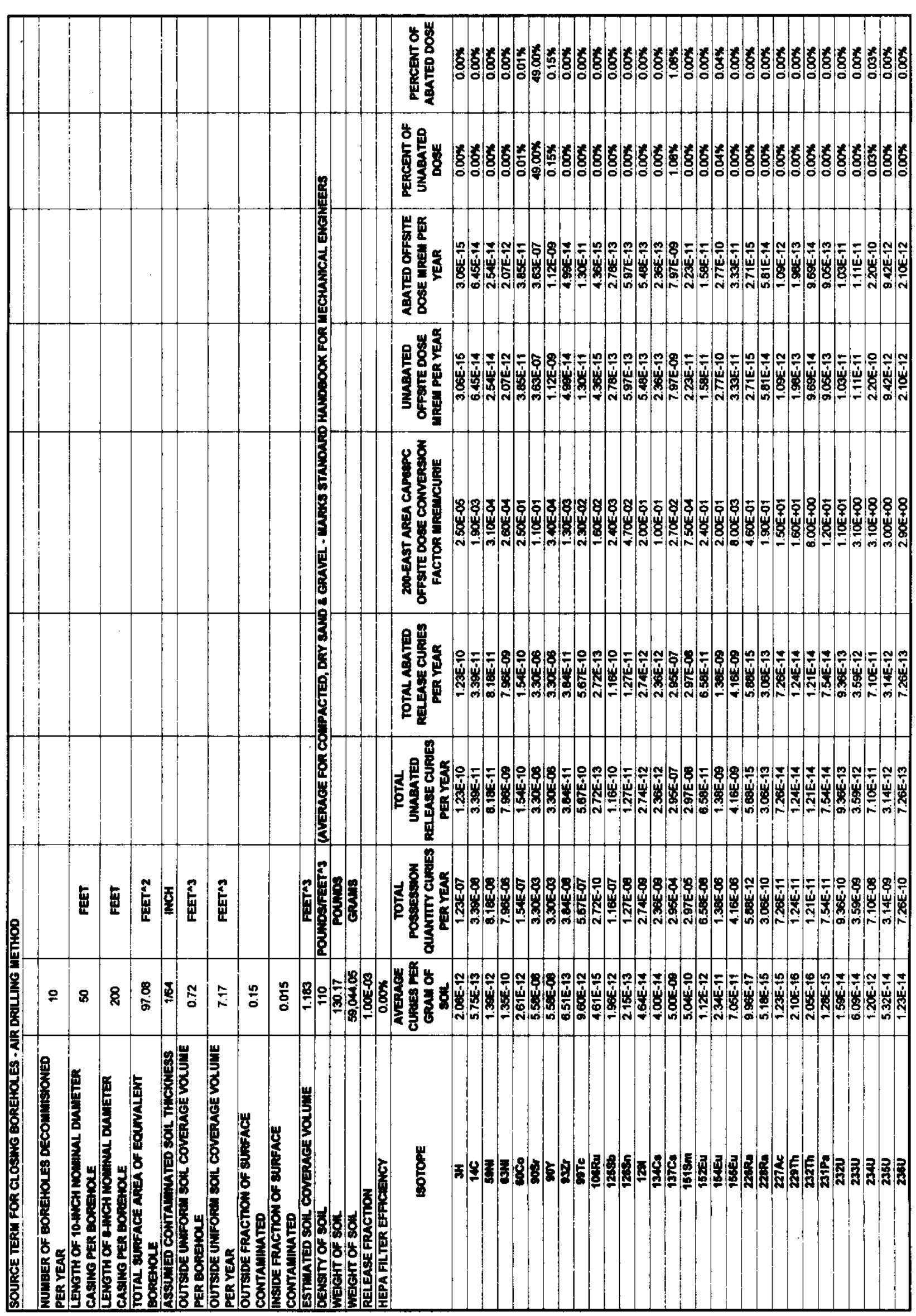



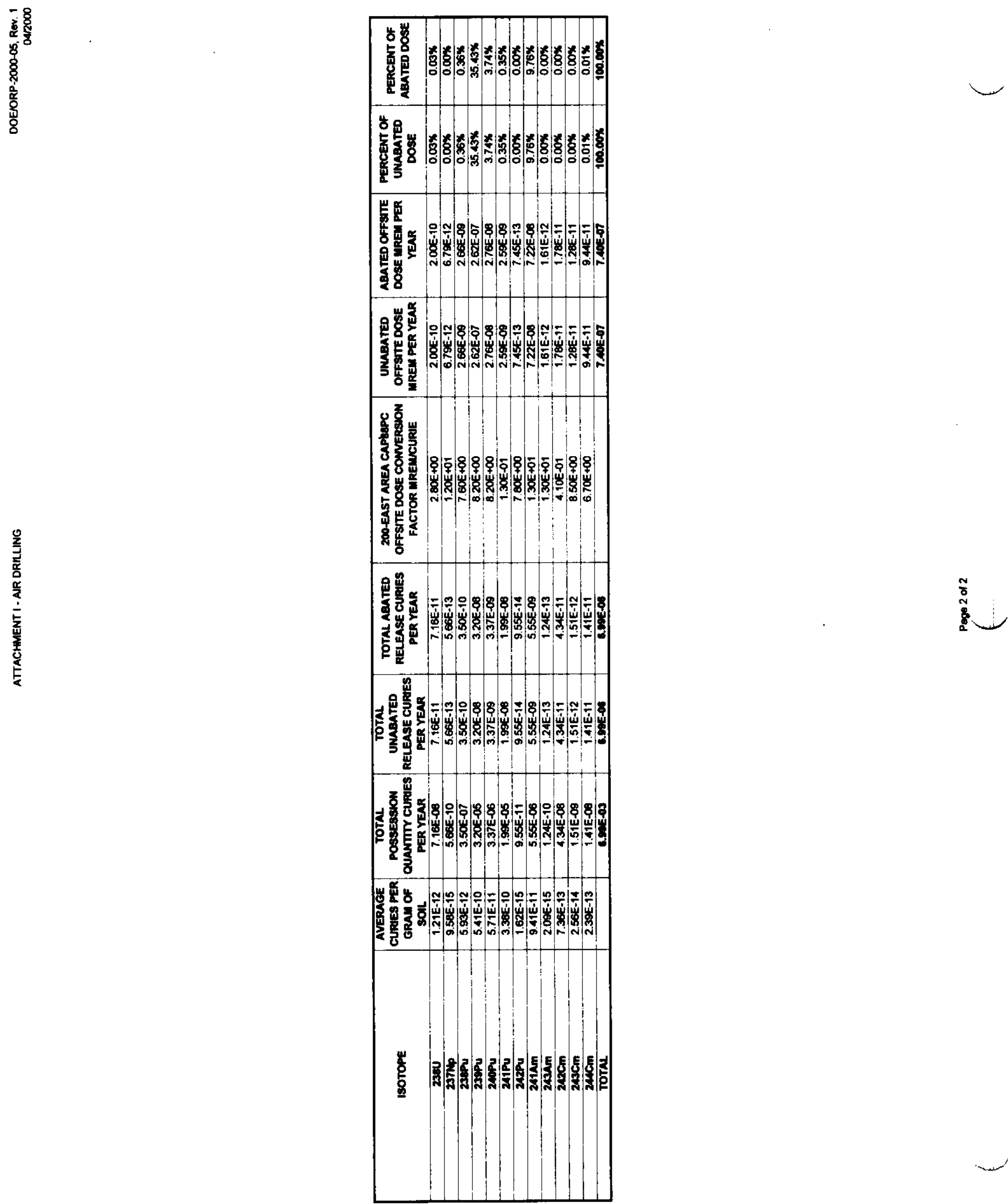


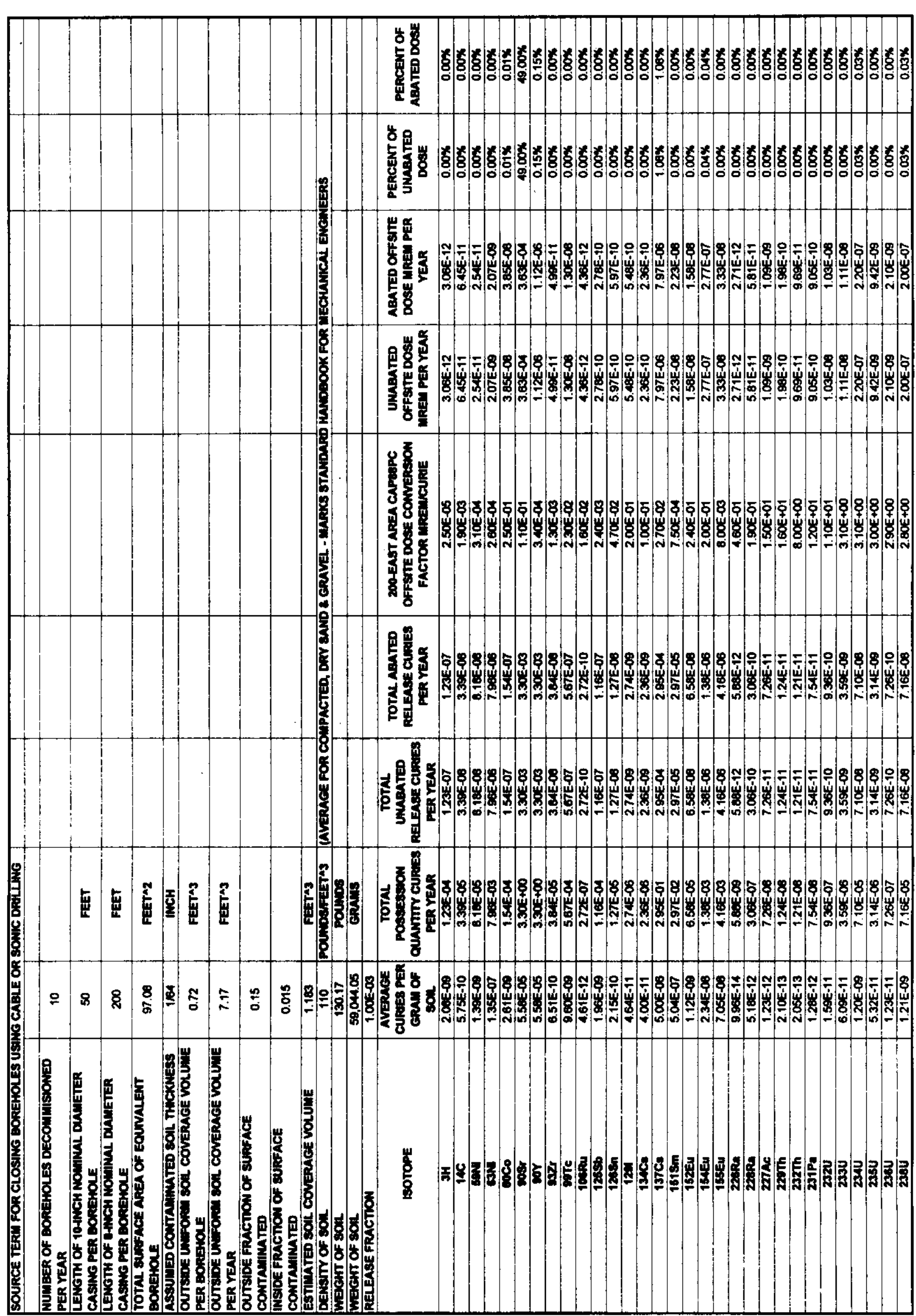




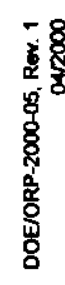

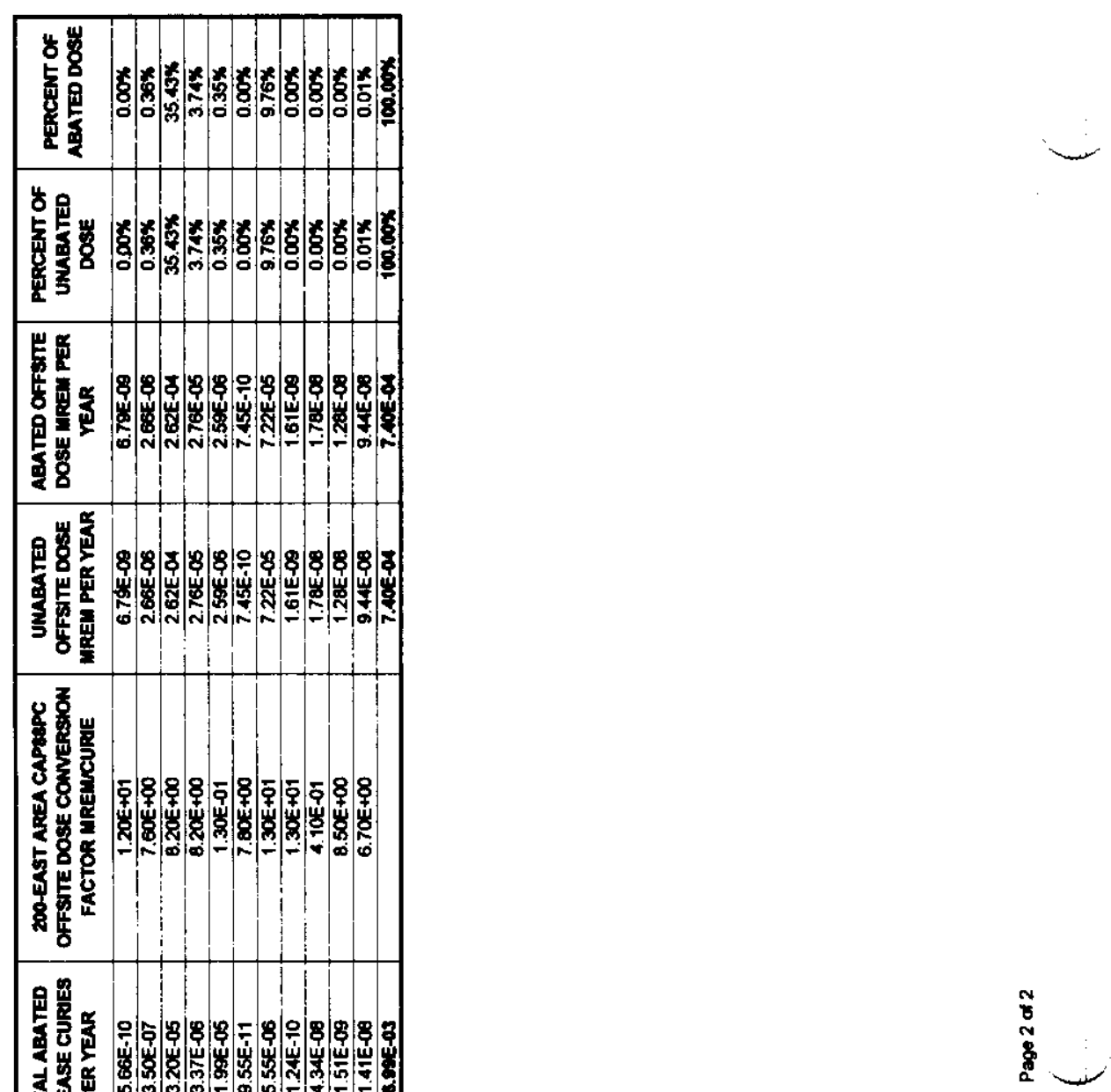




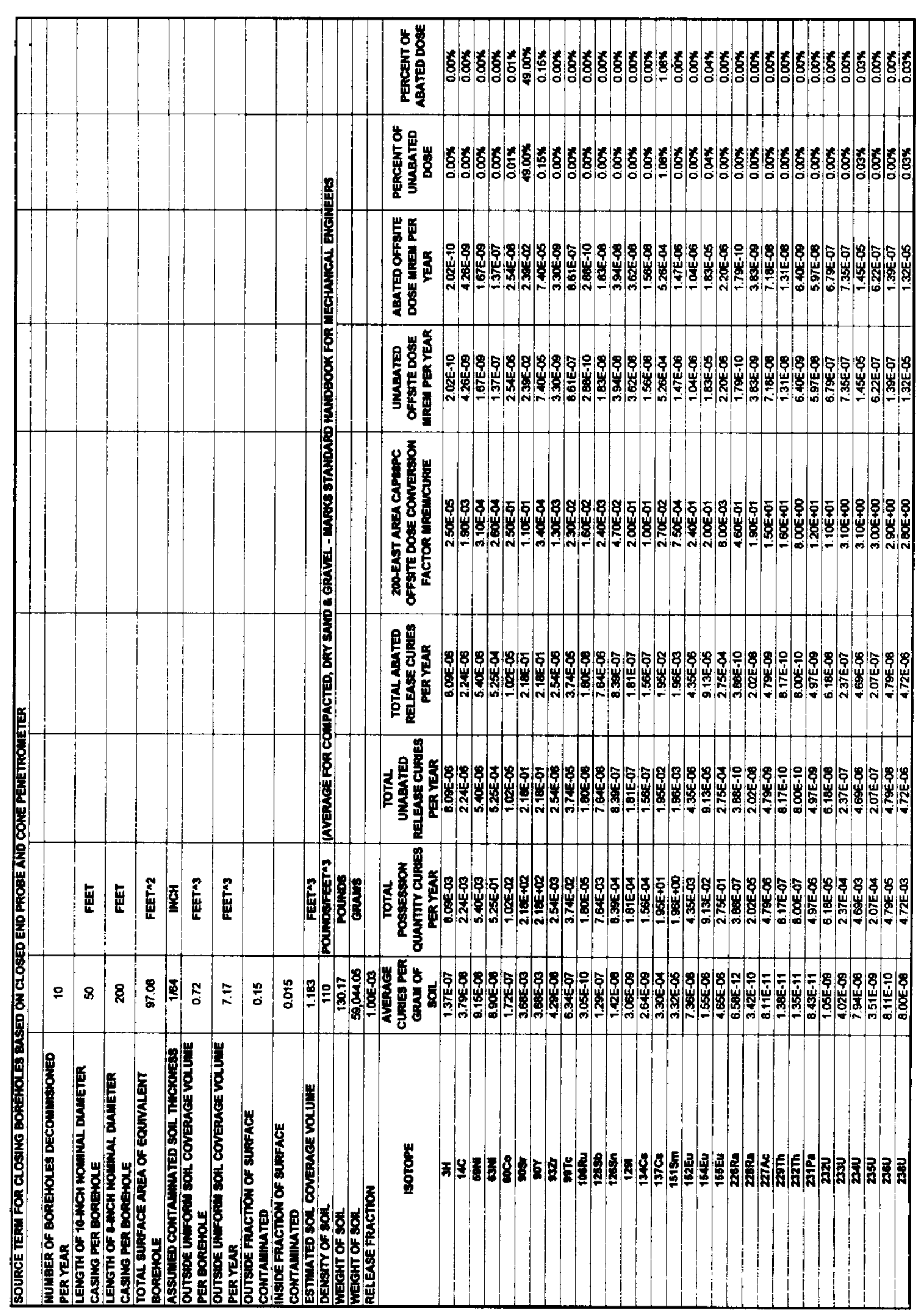




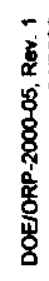

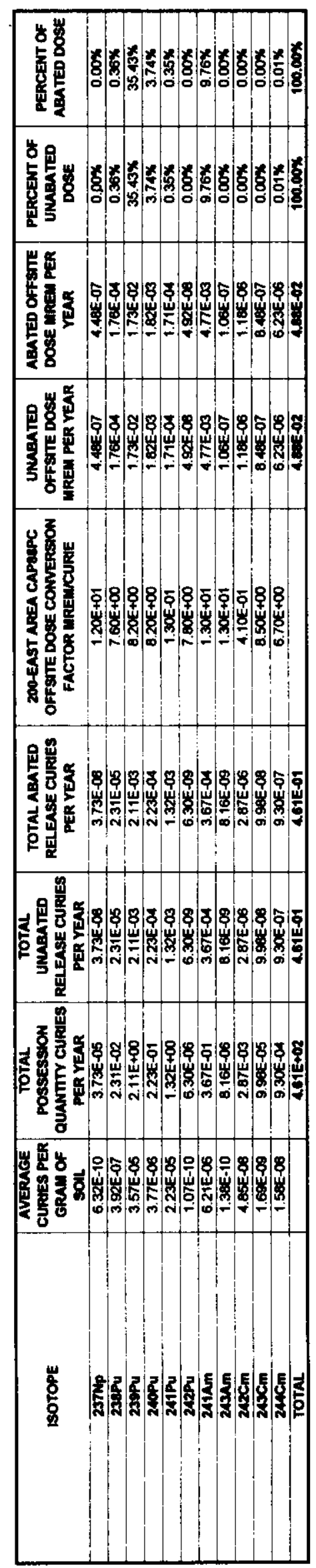

\begin{tabular}{l}
\multirow{8}{*}{} \\
\multirow{8}{8}{} \\
8 \\
0
\end{tabular} 
DOE/ORP-2000-05, Rev. 1

$04 / 2000$

\section{ATTACHMENT J}

SUMMARY OF POTENTIAL-TO-EMIT ASSUMPTIONS

DRILLING BOREHOLES/CLOSING BOREHOLES AND REMOVING CASING 
DOE/ORP-2000-05, Rev. 1

04/2000

This page intentionally left blank. 


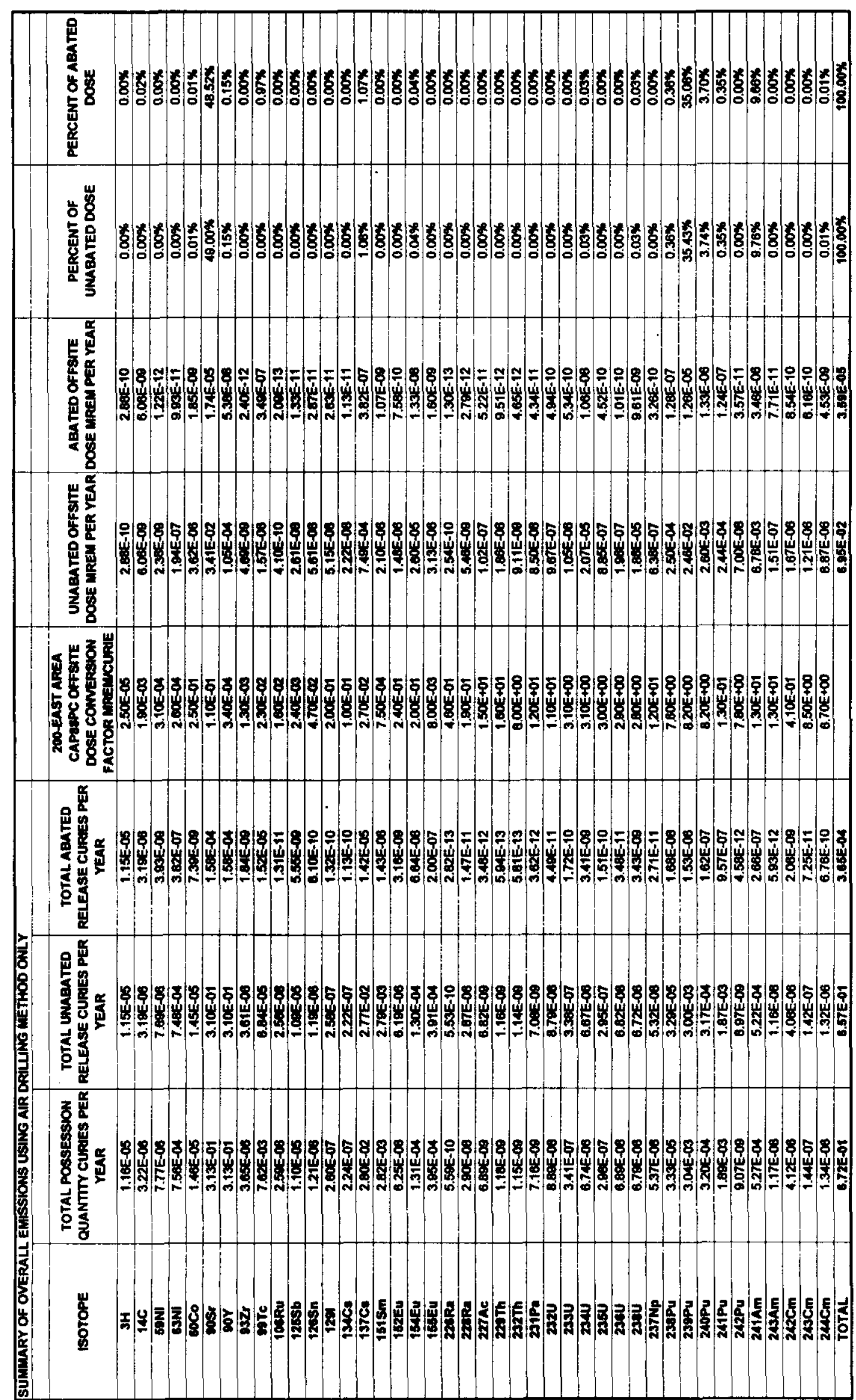


4 岁

7:

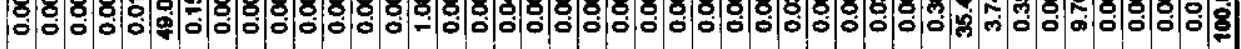

疍

11 - 11 . 110

密

宸

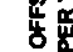

总

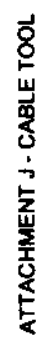

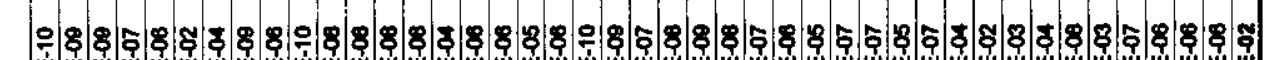

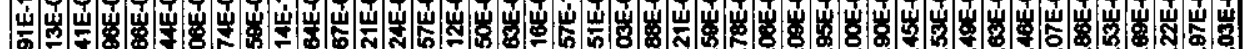

喓

N

政

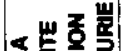

188 .

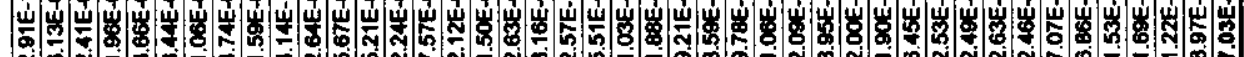

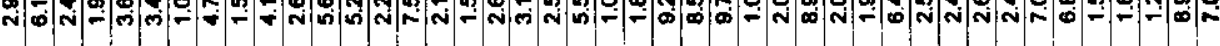

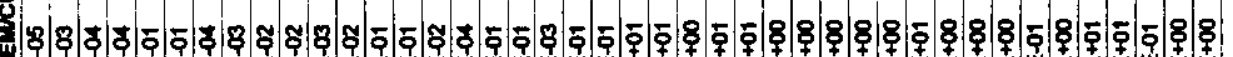

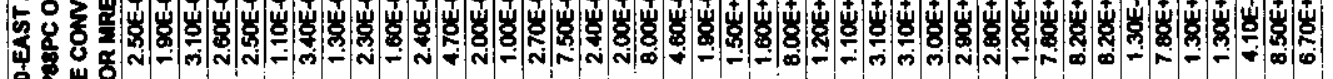

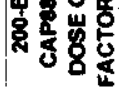

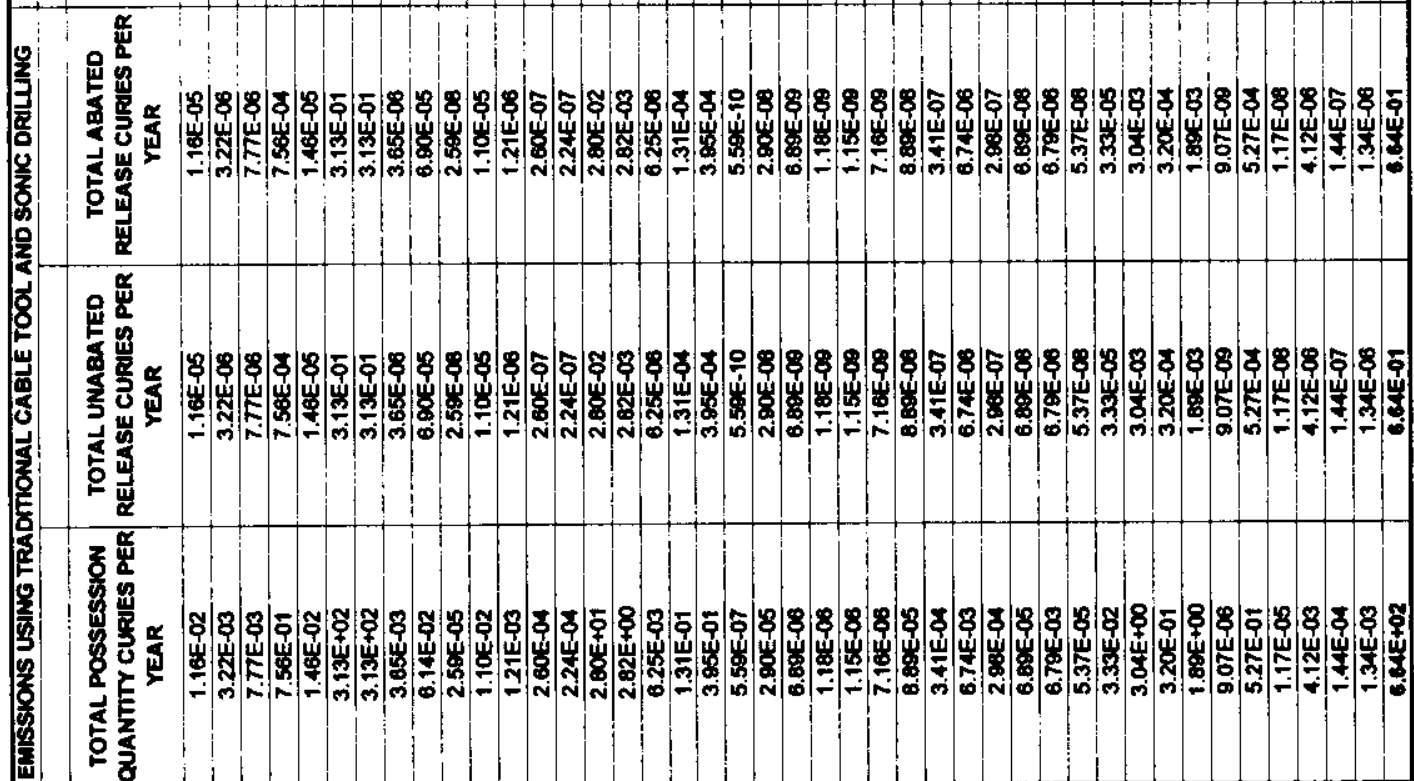

尚

学

崖 


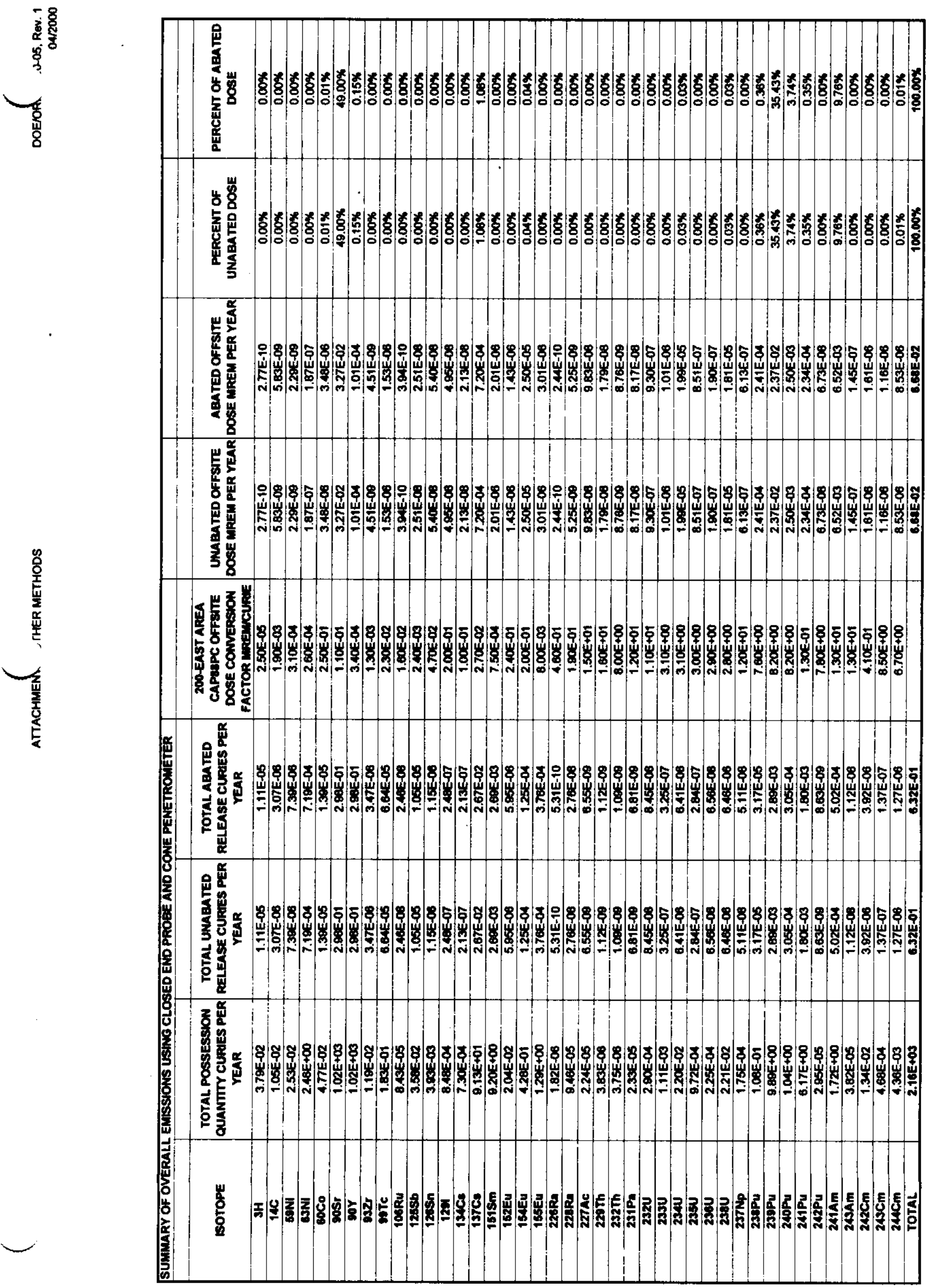


This page intentionally left blank. 
DOE/ORP-2000-05, Rev. 1

$04 / 2000$

\section{ATTACHMENT K}

\section{POTENTIAL-TO-EMIT EXAMPLE CALCULATION}


This page intentionally left blank. 


\section{Vadose Zone Sampling Example Calculation}

$$
\text { disintegration }:=1 \text { curie }:=3.7 \cdot 10^{10} \cdot \frac{\text { disintegration }}{\mathrm{sec}} \quad \mathrm{rem}:=1 \text { millirem }=.001 \cdot \mathrm{rem}
$$

The first step is to determine the annual handling IImit which corresponds to the actual volume of soil to be removed. Based on fleld experlence, the volume of soll that has been removed is observed to expand approximately $15 \%$ because the soil is no longer compacted.

$$
\begin{aligned}
& \text { Diameter } 10 \_ \text {inch }:=10 \text {.in Length } 10_{-} \text {inch }:=50 \cdot \mathrm{ft} \\
& \text { Diameter } 8 \text { _inch }_{=8} \text { in Length } 8 \text { inch }:=200 \mathrm{ft}
\end{aligned}
$$

$$
\text { Borehole : }=\frac{10}{\mathrm{yr}}
$$$$
\text { Volume }_{10 \_ \text {inch }}:=\pi \cdot\left[\frac{\frac{\text { Diameter }_{10} \text { inch }}{2}}{12 \cdot \frac{\mathrm{in}}{\mathrm{ft}}}\right]^{2} \cdot \text { Length } 10 \_ \text {inch } \quad \text { Volume }_{10 \_ \text {inch }}=27.271 \mathrm{ff}
$$$$
\text { Volume }_{8 \_ \text {inch }}:=\pi \cdot\left[\frac{\frac{\text { Diameter }_{8} \text { inch }}{2}}{12 \cdot \frac{\text { in }}{\mathrm{ft}}}\right]^{2} \cdot \text { Length }_{8 \text { inch }} \text { Volume }_{8 \text { inch }}=69.813 \mathrm{Ft}^{3}
$$

$$
\text { Volume }_{\text {Actual }}:=1.15 \cdot\left(\text { Volume }_{10 \_ \text {inch }}+\text { Volume }_{8} \text { inch }\right) \quad \text { Volume }_{\text {Actual }}=111.647 \mathrm{ft}^{3}
$$


The average verticle span of soll contamination is assumed to be 20 feet. This 20 feet can be anywhere along the depth of the borehole. For conservatism assume that the 20 feet of soil contamination corresponds to the 10 inch diameter.

Length contamination $:=20 \cdot \mathrm{ft}$

Volume $_{\text {contamination }}:=1.15 \cdot \pi \cdot\left[\frac{\frac{\text { Diameter }_{10 \_ \text {inch }}}{2}}{12 \cdot \frac{\text { in }}{\mathrm{ft}}}\right]^{2} \cdot$ Length contamination

Volume $_{\text {contamination }}=12.545 \mathrm{ft}^{3}$

The average density of loose soll is 97.5 pounds per cubic feet (Marks' Standardard Handbook for Mechanical Engineers, 9th Edition)

$\rho_{\text {soil }}:=97.5 \cdot \frac{\mathrm{lb}}{\mathrm{ft}^{3}}$

Soil ${ }_{\text {contamination }}:=$ Volume $_{\text {contamination }} \cdot \rho_{\text {soil }} \quad$ Soil contamination $=1.22310^{3} \mathrm{elb}$

The amount of contaminated soll that reaches the HEPA filter in one year is as follows:

HEPA contamination $:=$ Soil contamination $\cdot$ Borehole

HEPA $_{\text {contamination }}=1.223 \cdot 10^{4} \cdot \frac{\mathrm{lb}}{\mathrm{yr}} \quad \mathrm{HEPA}_{\text {contamination }}=5.54810^{6} \cdot \frac{\mathrm{gm}}{\mathrm{yr}}$

Air Rotary Drilling Annual Handling Limit Calculation for Pu-239:

$$
\begin{aligned}
& \eta_{\text {HEPA }}:=.9995 \quad \text { Cs } \text { contamination }:=5.0 \cdot 10^{-9} \cdot \frac{\text { curie }}{\mathrm{gm}} \\
& \text { Pu239_Cs_137 ratio }:=1.08 \cdot 10^{-1}
\end{aligned}
$$

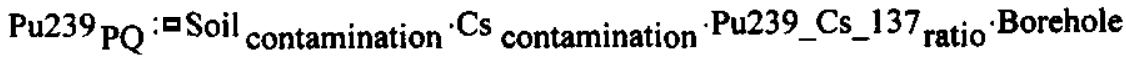

$$
\begin{aligned}
& { }^{\mathrm{Pu} 239} \mathrm{PQ}=2.99610^{-3} \frac{\text { curie }}{\mathrm{yr}}
\end{aligned}
$$




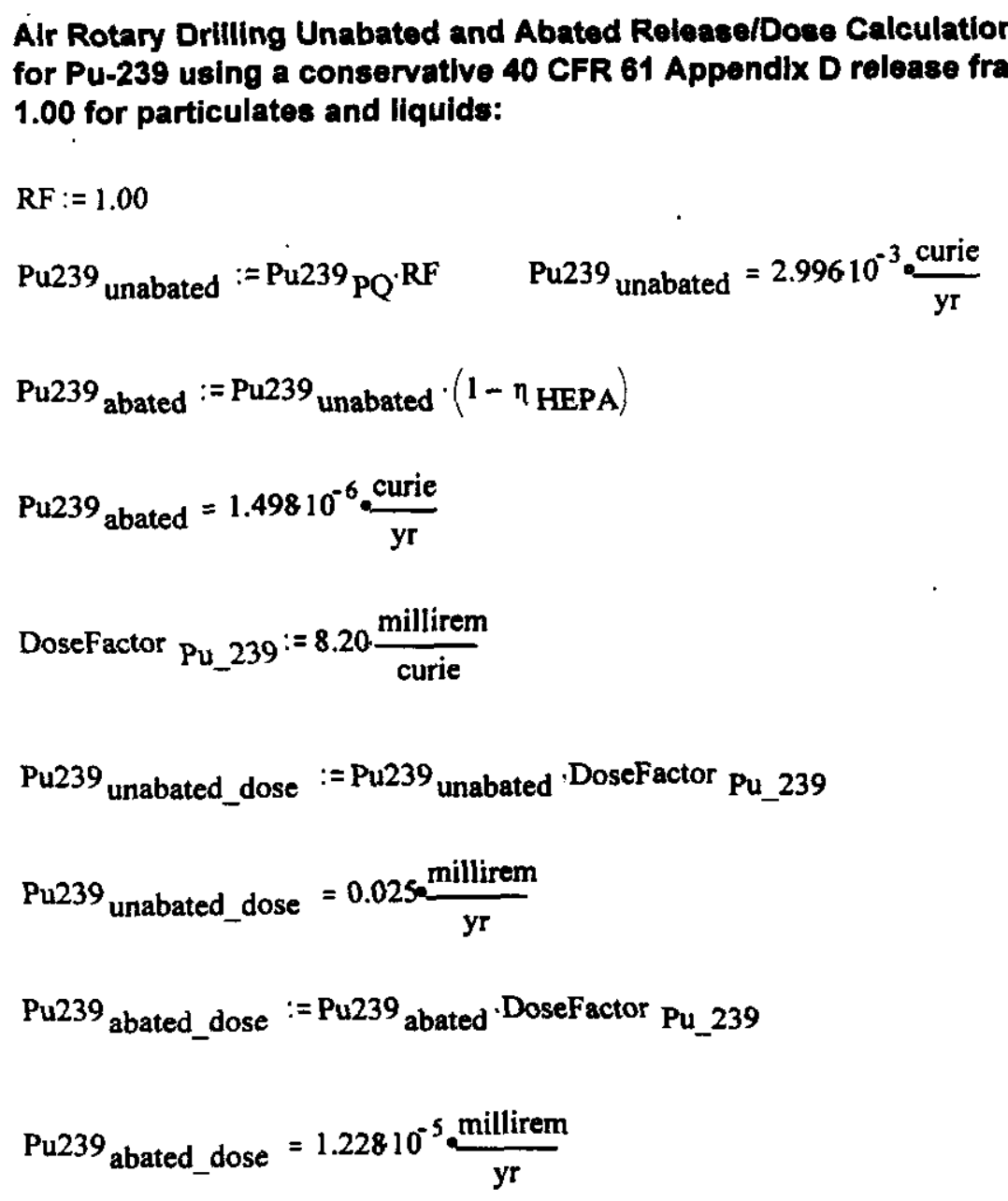

For the other drilling techniques (0.9., closed end probe and cone penetrometer) the source of airborne emiselons is expected to come from the volume of soll extracted during sampling activities. The maximum soll sample volume from each borehole ls based on obtaining up to 10, 4-inch diameter by 2 foet long samples.

Sample $_{\text {volume }}:=10 \cdot 2 \cdot \mathrm{ft} \cdot \pi \cdot\left(\frac{4 \cdot \mathrm{in}}{2 \cdot 12 \cdot \frac{\mathrm{in}}{\mathrm{ft}}}\right)^{2}$

Sample $_{\text {volume }}=1.745 \mathrm{ft}^{3}$ 
The total fraction of eamples from the contaminated zone is expected to be 0.25 . Since the samples are being extracted from the well, the samples are compacted; therefore, an average density for compacted soll was used.The average density of loose soll is $\mathbf{9 7 . 5}$ pounds per cubic feet (Marks'

Standard Handbook for Mechanical Engineers, 9th Edition) The maximum volume of contaminated soil per year is calculated below.

fraction contaminated_zone $:=.25$

$\rho_{\text {soil_compacted }}:=110 \cdot \frac{\mathrm{lb}}{\mathrm{ft}^{3}}$

Soil contaminated $:=$ Sample $_{\text {volume }}$ fraction $_{\text {contaminated_zone }}^{\cdot \rho}$ soil_compacted $\cdot$ Borehole

Soil contaminated $=479.966 \frac{\mathrm{lb}}{\mathrm{yr}} \quad$ Soil contaminated $=2.177 .10^{5} \cdot \frac{\mathrm{gm}}{\mathrm{yr}}$

Other Drilling Techniques Annual Possession Quantity Calculation for Pu-239:

$$
\begin{aligned}
& \text { Cs } \text { contamination }:=3.30 \cdot 10^{-4} \cdot \frac{\text { curie }}{\mathrm{gm}} \\
& \text { Pu239_Cs_137 ratio }:=1.08 \cdot 10^{-1} \\
& { }_{\mathrm{Pu} 239} \mathrm{PQ}:=\text { Soil } \text { contaminated } \cdot \text { Cs } \text { contamination } \cdot \mathrm{Pu} 239 \_C s \_137 \text { ratio } \\
& { }^{\mathrm{Pu} 239} \mathrm{PQ}=7.759 \cdot \frac{\text { curie }}{\mathrm{yr}}
\end{aligned}
$$


Other Drilling Techniques Unabated and Abated Release/Dose Calculation for Pu-239 using a conservative 40 CFR 61 Appendix D release fraction of 1E-03 for particulates and llquide and that only $10 \%$ of the contaminated soil is exposed to atmosphere:

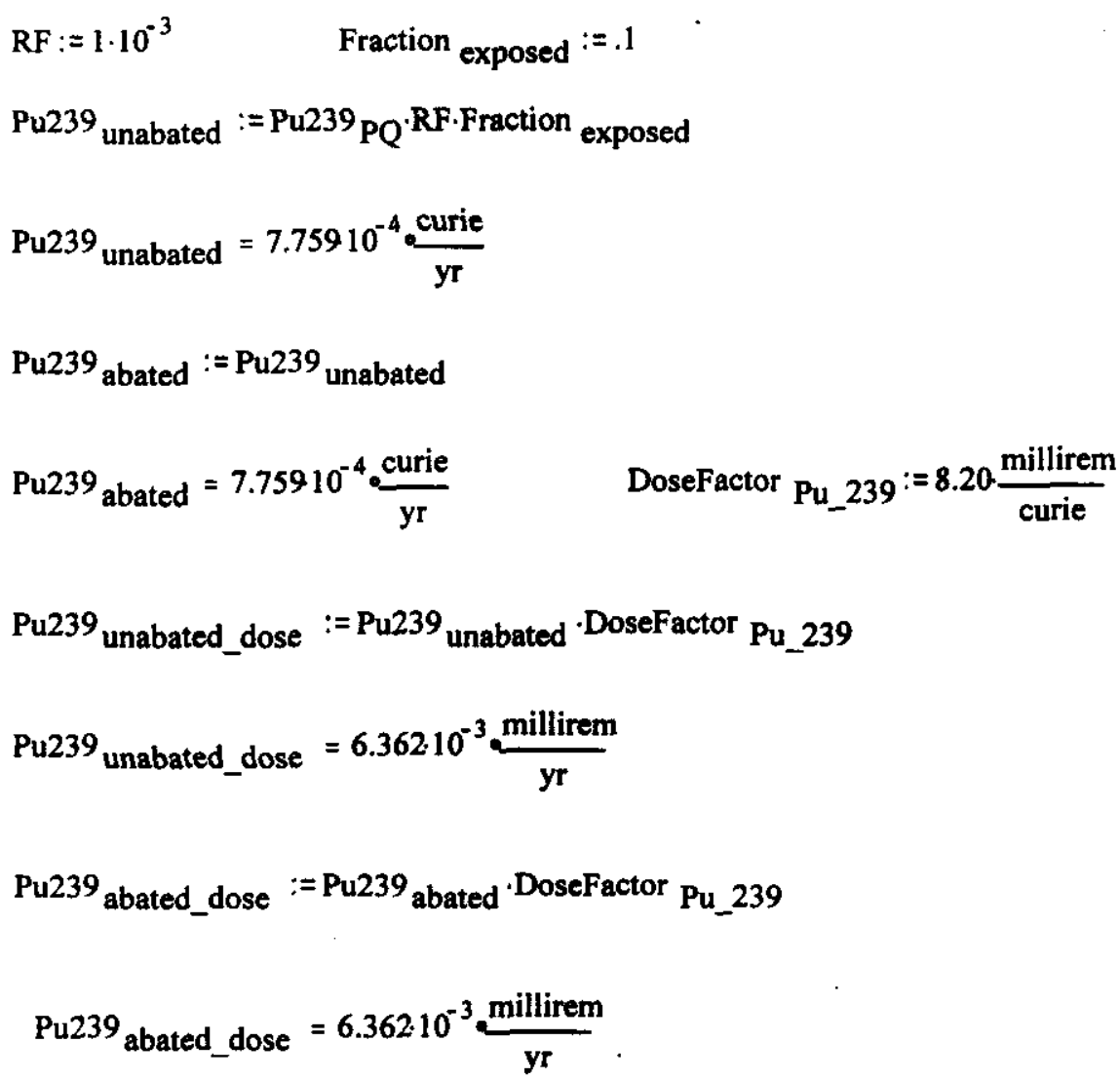


For Casing Removal:

Assumed contaminated soll thickness on casing:

soil $_{\Delta}:=\frac{1}{64} \cdot$ in

For 10-inch casing, the estimated soil volume is:

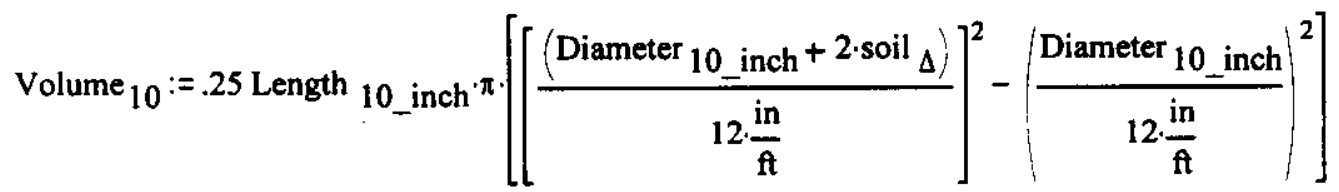

Volume $_{10}=0.171$ คf $^{3}$

For 8-inch casing, the estimated soil volume is:

Volume $_{8}:=.25$ Length 8 inch $\left.\cdot \pi \cdot\left[\frac{\left(\text { Diameter } 8 \_ \text {inch }+2 \cdot \text { soil }_{\Delta}\right)}{12 \cdot \frac{\mathrm{in}}{\mathrm{ft}}}\right]^{2}-\left(\frac{\text { Diameter }_{8} \text { inch }}{12 \cdot \frac{\mathrm{in}}{\mathrm{ft}}}\right)^{2}\right]$

Volume $_{8}=0.546 \mathrm{oft}^{3}$

The total soil volume on the casing if uniformly coated is:

$$
\begin{aligned}
& \text { Volume }_{\text {uniform }}:=\text { Borehole } \cdot\left(\text { Volume }_{10}+\text { Volume }_{8}\right) \\
& \text { Volume }_{\text {uniform }}=7.1720 \frac{\mathrm{ft}^{3}}{\mathrm{yr}}
\end{aligned}
$$


Based on previous experience, approximately $15 \%$ of the exterior surface of the casing is contaminated. For conservatism, an extra $10 \%$ of the exterior surface contamination is added to account for any potentlal contamination that may be within the interior of the casing. Therefore, the adjusted soll volume is:

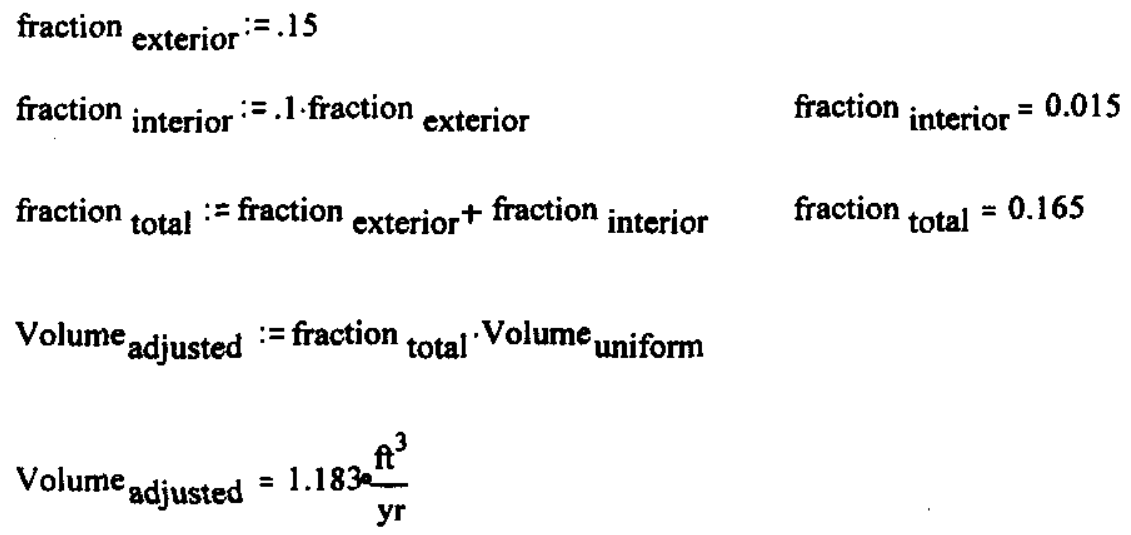

The average density of compacted soll is 110 pounds per cublc feet (Marks' Standard Handbook for Mechanical Engineers, 9th Edition)

$\rho_{\text {soil_compacted }}:=110 \cdot \frac{\mathrm{lb}}{\mathrm{ft}^{3}}$

The total weight of soil on the casing ls:

$$
\begin{aligned}
& \text { Weight soil_casing }:=\text { Volume }_{\text {adjusted }} \cdot \rho \text { soil_compacted } \\
& \text { Weight soil_casing }=59044 \cdot \frac{\mathrm{km}}{\mathrm{yr}}
\end{aligned}
$$


Annual handling limit calculation for Pu-239 associated with casing removal:

$$
\begin{aligned}
& \text { Cs } \text { contamination }:=3.3010^{-4} \cdot \frac{\text { curie }}{\mathrm{gm}} \quad \text { (Based on other drilling methods) } \\
& \text { Pu239_Cs_137 } \text { ratio }:=1.08 \cdot 10^{-1} \\
& \mathrm{Pu} 239_{\mathrm{PQ}}:=\text { Weight } \text { soil_casing } \cdot \text { Cs } \text { contamination } \cdot \text { Pu239_Cs_137 } \text { ratio } \\
& \mathrm{Pu} 239_{\mathrm{PQ}}=2.104 \frac{\mathrm{curie}}{\mathrm{yr}} \\
& \mathrm{RF}:=.001
\end{aligned}
$$

Casing Removal Unabated Release/Dose Calculation for Pu-239:

$$
\begin{aligned}
& \mathrm{Pu}^{239} \text { unabated }:=\mathrm{Pu} 239_{\mathrm{PQ}} \cdot \mathrm{RF} \\
& \text { Pu239 }{ }_{\text {unabated }}=2.10410^{-3} \frac{\text { curie }}{\mathrm{yr}} \\
& \text { DoseFactor Pu_239: }=8.20 \frac{\text { millirem }}{\text { curie }} \\
& \text { Pu239 unabated_dose }:=\text { Pu239 unabated } \text { DoseFactor } P_{\text {Pu_239 }} \\
& \text { Pu239 unabated_dose }=0.017 \frac{\text { millirem }}{\mathrm{yr}} \\
& \text { Pu239 }{ }_{\text {unabated_dose }}=1.73 \cdot 10^{-2} \frac{\text { millirem }}{\mathrm{yr}}
\end{aligned}
$$




\section{ATTACHMENT L}

TWRS ALARACT DEMONSTRATION FOR PACKAGING AND TRANSPORTATION OF EQUIPMENT AND VEHICLES 
DOE/ORP-2000-05, Rev. 1

$04 / 2000$

This page intentionally left blank. 


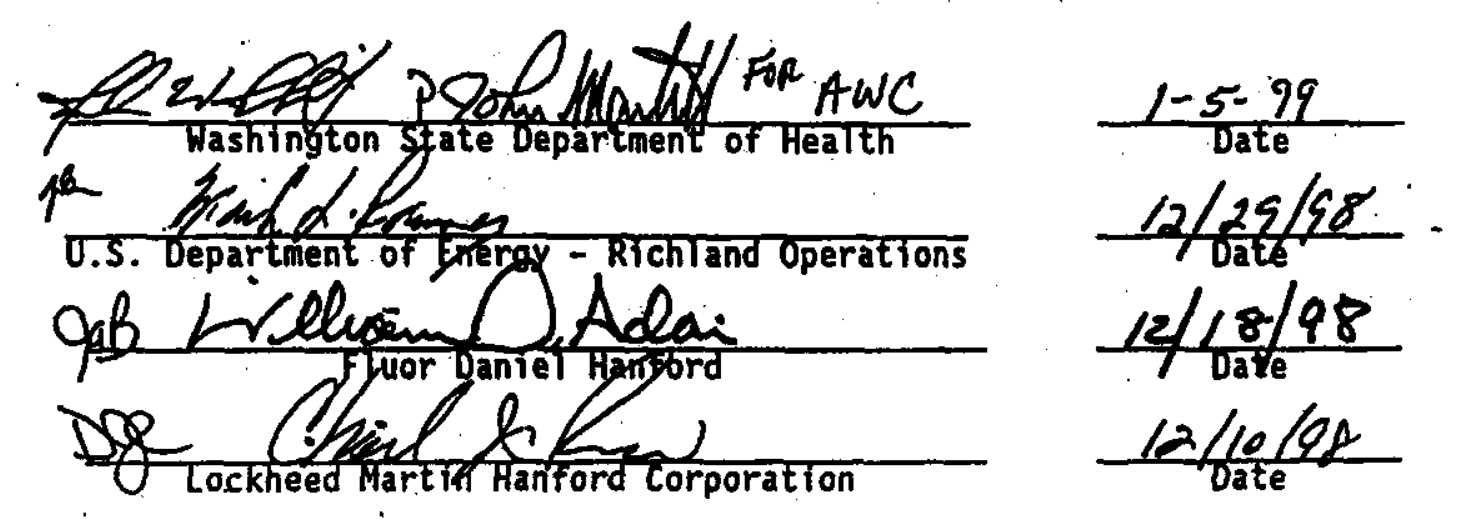

Rev. 0

$11 / 19 / 98$

41 


\section{TWRS ALARACT DEYONSTRATION FOR}

PACKAGTNG AND TRANSPORTATTON OF EOUIPWTII \& VEHICLES

\section{Descriotion of Activity:}

Equipment and vehicles that become contaminated during work activities are reused when possible. If the equipment or vehicle is to be reused or stored in a contamination area, the removable activity levels on the surface of the ttem, or the outer-most container, must be in accordance with HSRCM-1, Table 2-4 (or latest revision). If the equipment or vehicle is to be transported to another facility, the surface of the item; or the outermost coritainer, must meet the requirements under the Radiological Controls section 1isted below.

- Emission pathway - Fugitive/diffuse sourçes

- TWRS Facility Description - All TWRS facilities

2. Radiological Controls:

Removable contamination on the surface of the item, or the outer-most container, must be $<1,000 \mathrm{dpm} / 100 \mathrm{~cm}^{2}$ beta/gamma and/or $<20 \mathrm{dpm} / 100 \mathrm{~cm}^{2}$ alpha if the equipment or vehicle is leaving the contamination area

3. Monitoring:

- Radiological surveys (swipes for removable contamination) of work area.

- Post job survey

4. Records/Decumentation:

- Radiological work permit

- Radiological survey report(s) 
DOE/ORP-2000-05, Rev. 1

$04 / 2000$

\section{ATTACHMENT M}

DISCUSSION OF BEST AVAILABLE RADIONUCLIDE CONTROL TECHNOLOGY 
DOE/ORP-2000-05, Rev. 1

$04 / 2000$

This page intentionally left blank. 


\section{DISCUSSION OF BEST AVAILABLE RADIONUCLIDE CONTROL TECHNOLOGY (REQUIREMENT 16)}

Providing cost factors for construction, operation, and maintenance of the proposed control technology components is not required because the following BARCT discussion is provided. The BARCT is defined by WAC $246-247-030$ as follows:

"Technology that will result in a radionuclide emission limitation based on the maximum degree of reduction for radionuclides from any proposed newly constructed or significantly modified emission units that the licensing authority determines is achievable on a case-by-case basis. A BARCT compliance demonstration must consider energy, environmental, and economic impacts, and other costs through examination of production processes, and available methods, systems and techniques for control of radionuclide emissions. A BARCT compliance demonstration is the conclusion of an evaluative process that results in the selection of the most effective control technology from all know feasible alternatives. In no event shall application of BARCT result in emissions of radionuclides that could exceed the applicable standards of WAC 246-247-040. Control technology that meets BARCT requirements also meets ALARCT requirements."

As stated in WAC 246-247-120, only those radionuclides comprising more than 10 percent of the unabated dose need to be evaluated. All of the dose is due to particulate radionuclides. The Washington State Department of Health has provided guidance that HEPA filters generally are considered BARCT for particulate emissions (WDOH 1992).

It is proposed, pursuant to the quoted citation, that the ventilation system described in Section 8.0 and the controls (engineering and administrative) (described in Section 9.0) be approved as BARCT for the proposed activities. 
DOE/ORP-2000-05, Rev. 1

$04 / 2000$

This page intentionally left blank. 
DOE/ORP-2000-05, Rev. 1

$04 / 2000$

\section{ATTACHMENT N}

\section{CAP88PC RUN DATA AND INFORMATION}


DOE/ORP-2000-05, Rev. 1

$04 / 2000$

This page intentionally left blank. 
Hanford Map Distances Version 1.8

by Paul D. Rittmann PhD CHP

Map Data File (HMD.DAT): Map Coordinate File PDR 5/13/98

Release Location: PUREX

\begin{tabular}{ccc} 
Special Point Information \\
Number & Longitude & Latitude \\
\hdashline 1 & 24.590 & 27.615 \\
2 & 23.411 & 29.083 \\
3 & 20.051 & 28.316
\end{tabular}

Transport

Direction Distance

Notes:

(1) NRC Regulatory Guide 1.145 (Rev 1, 1982) requires finding the smallest distance in a 45 degree sector centered on the direction of interest.

(2) The last digit is questionable, and is for information only.

Release Location: PUREX

Boundary Definition:

Highway 240 + the Near Bank of the Columbia River

Table of Distances from the Release Location to the Boundary

\begin{tabular}{lcr} 
Transport & \multicolumn{2}{c}{ Distances, meters } \\
Direction & Sector & NRC 1.145 \\
-1 & 9270 & $8550 \mathrm{~m}$ \\
$1 \mathrm{~S}$ & 9550 & $8550 \mathrm{~m}$ \\
$2 \mathrm{SSW}$ & 8550 & $8550 \mathrm{~m}$ \\
$3 \mathrm{SW}$ & 9270 & $8550 \mathrm{~m}$ \\
$4 \mathrm{WSW}$ & 12440 & $9270 \mathrm{~m}$ \\
$5 \mathrm{~W}$ & 16170 & $12440 \mathrm{~m}$ \\
$6 \mathrm{WNW}$ & 12930 & $12920 \mathrm{~m}$ \\
$7 \mathrm{NW}$ & 12920 & $12920 \mathrm{~m}$ \\
$8 \mathrm{NNW}$ & 15470 & $12920 \mathrm{~m}$ \\
$9 \mathrm{~N}$ & 13490 & $11120 \mathrm{~m}$ \\
$10 \mathrm{NNE}$ & 11120 & $10980 \mathrm{~m}$ \\
$11 \mathrm{NE}$ & 10980 & $10980 \mathrm{~m}$ \\
$12 \mathrm{ENE}$ & 13110 & $10980 \mathrm{~m}$ \\
$13 \mathrm{E}$ & 19270 & $12300 \mathrm{~m}$ \\
$14 \mathrm{ESE}$ & 12300 & $12300 \mathrm{~m}$ \\
$15 \mathrm{SE}$ & 12520 & $9270 \mathrm{~m}$ \\
$16 \mathrm{SSE}$ & & \\
\hline$--------~$
\end{tabular}

Notes:

(1) NRC Regulatory Guide 1.145 (Rev 1, 1982) requires finding the smallest distance in a 45 degree sector centered on the direction of interest.

(2) The last digit is questionable, and is for information only. 


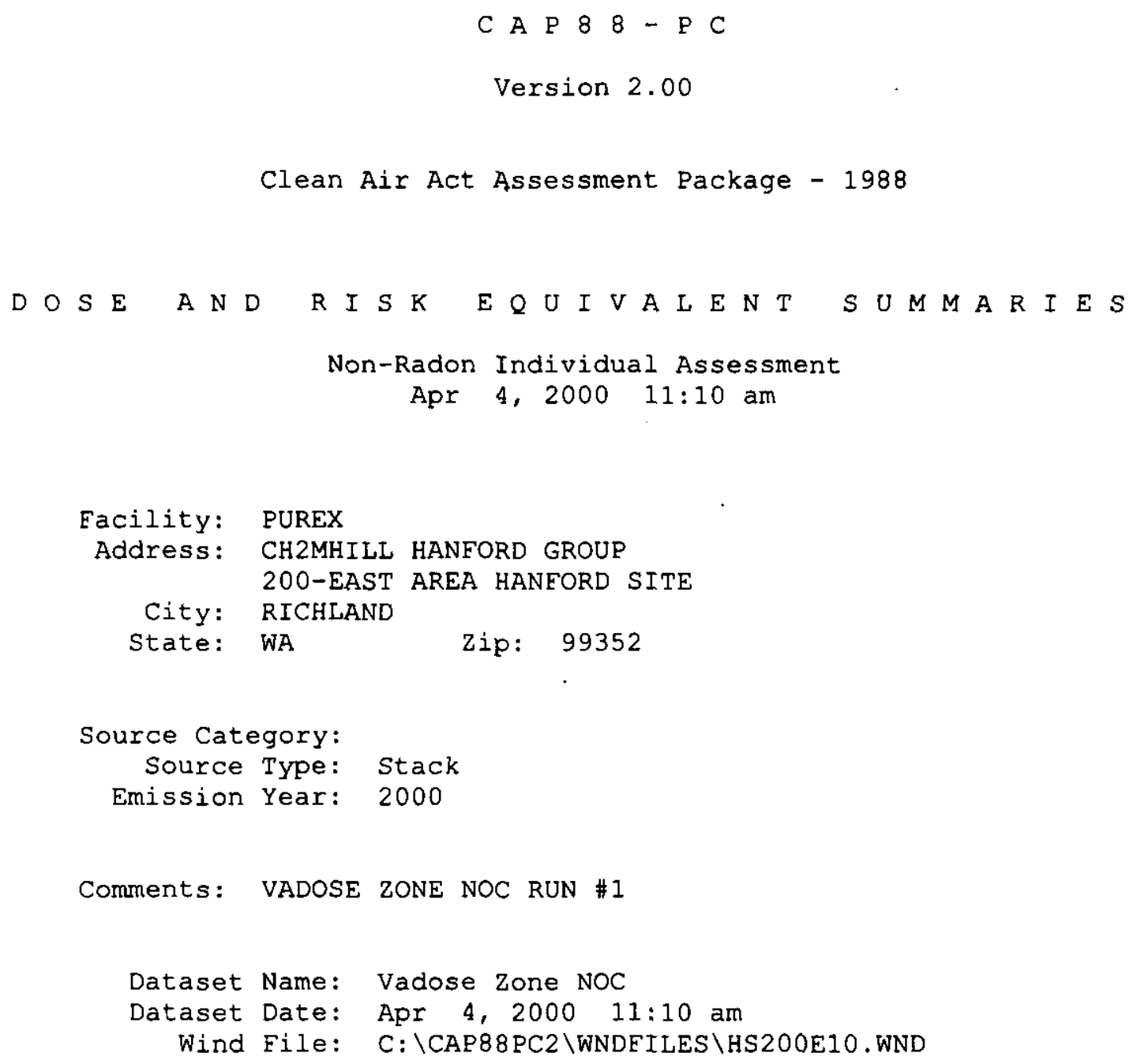


Apr 4, 2000 11:10 am

SUMMARY

Page 1

ORGAN DOSE EQUIVALENT SUMMARY

\begin{tabular}{lc} 
Organ & $\begin{array}{c}\text { Selected } \\
\text { Individual } \\
\text { (mrem/y) }\end{array}$ \\
\hline GONADS & $1.33 \mathrm{E}-03$ \\
BREAST & $1.37 \mathrm{E}-03$ \\
R MAR & $9.44 \mathrm{E}-02$ \\
LUNGS & $2.16 \mathrm{E}-03$ \\
THYROID & $1.41 \mathrm{E}-03$ \\
ENDOST & $2.08 \mathrm{E}-01$ \\
RMNDR & $3.47 \mathrm{E}-03$ \\
EFFEC & $1.95 \mathrm{E}-02$
\end{tabular}

PATHWAY EFFECTIVE DOSE EQUIVALENT SUMMARY

Selected

Individual

Pathway (mrem/y)

INGESTION

$1.51 \mathrm{E}-02$

INHALATION

$4.27 \mathrm{E}-03$

AIR IMMERSION

$8.73 \mathrm{E}-09$

GROUND SURFACE

$4.60 \mathrm{E}-05$

$1.94 \mathrm{E}-02$

EXTERNAL

4. $60 E-05$

TOTAL

1. $95 \mathrm{E}-02$ 
DOE/ORP-2000-05, Rev. 1

04/2000

Apr $4,2000 \quad 11: 10$ am

SUMMARY

Page 2

NUCLIDE EFFECTIVE DOSE EQUIVALENT SUMMARY

Nuclide

$\mathrm{H}-3$

$\mathrm{C}-14$

$\mathrm{NI}-59$

$\mathrm{NI}-63$

$\mathrm{CO}-60$

SR-90

$Y-90$

ZR-93

TC-99

RH-106

SB- 125

SN -126

I -129

CS -134

CS -137

SM-151

EU- 152

EU-154

EU-155

$\mathrm{RA}-226$

$R A-228$

$\mathrm{AC}-227$

$\mathrm{TH}-229$

TH -232

PA-231

TOTAL
Selected

Individual (mrem/y)

$2.84 \mathrm{E}-10$

2. $93 E-09$

3. $86 \mathrm{E}-09$

1. $95 \mathrm{E}-07$

5. 06E-06

1. $87 \mathrm{E}-02$

1. $72 \mathrm{E}-04$

1. $07 \mathrm{E}-08$

7. $42 \mathrm{E}-07$

2. $70 \mathrm{E}-28$

$4.02 E-07$

9. 30E-08

2. $07 E-08$

2. $68 \mathrm{E}-08$

5. 30E-04

5. $12 \mathrm{E}-06$

2. 22E-06

3. $72 \mathrm{E}-05$

4. $77 \mathrm{E}-06$

3. $66 \mathrm{E}-10$

6. $09 \mathrm{E}-09$

2. $59 \mathrm{E}-07$

4. $86 \mathrm{E}-08$

2. $43 E-08$

2. $05 E-07$

1. $95 E-02$ 
CANCER RISK SUMMARY

Cancer
LEUKEMIA
BONE
THYROID
BREAST
LUNG
STOMACH
BOWEL
LIVER
PANCREAS
URINARY
OTHER

TOTAL
Selected Individual

Total Lifetime Fatal Cancer Risk

$2.64 \mathrm{E}-07$
$2.96 \mathrm{E}-08$
$6.30 \mathrm{E}-10$
$5.24 \mathrm{E}-09$
$1.21 \mathrm{E}-08$
$3.09 \mathrm{E}-09$
$8.41 \mathrm{E}-09$
$4.97 \mathrm{E}-09$
$3.12 \mathrm{E}-09$
$1.70 \mathrm{E}-09$
$3.82 \mathrm{E}-09$
$3.37 \mathrm{E}-07$

PATHWAY RISK SUMMARY

Pathway
INGESTION
INHALATION
AIR IMMERSION
GROUND SUREACE
INTERNAL
EXTERNAL

TOTAL
Selected Individual Total Lifetime Fatal Cancer Risk

$2.59 E-07$

7. $68 \mathrm{E}-08$

2. $08 \mathrm{E}-13$

1. $10 \mathrm{E}-09$

3. 36E-07

1. 10E-09

3. $37 \mathrm{E}-07$ 
NUCLIDE RISK SUMMARY

Nuclide

$\mathrm{H}-3$

C- 14

$\mathrm{NI}-59$

$\mathrm{NI}-63$

CO- 60

$S R-90$

$Y-90$

ZR-93

TC-99

$\mathrm{RH}-106$

$\mathrm{SB}-125$

SN-126

I -129

CS -134

CS -137

SM- 151

EU-152

EU-154

$\mathrm{EU}-155$

$\mathrm{RA}-226$

$\mathrm{RA}-228$

AC -227

$\mathrm{TH}-229$

$\mathrm{TH}-232$

$\mathrm{PA}-231$

TOTAL
Selected Individual Total Lifetime Fatal Cancer Risk

$7.70 \mathrm{E}-15$

$7.16 \mathrm{E}-14$

9. $56 \mathrm{E}-14$

$6.27 E-12$

1. $26 \mathrm{E}-10$

$3.16 \mathrm{E}-07$

$6.03 \mathrm{E}-09$

1. $00 \mathrm{E}-13$

$2.78 \mathrm{E}-11$

$6.48 E-33$

$9.76 \mathrm{E}-12$

2. $05 \mathrm{E}-12$

1. $80 \mathrm{E}-13$

$6.56 \mathrm{E}-13$

1. $39 \mathrm{E}-08$

1. $02 \mathrm{E}-10$

5. $36 \mathrm{E}-11$

9. $09 \mathrm{E}-10$

1. $10 \mathrm{E}-10$

$6.92 \mathrm{E}-15$

8. 31E-14

2. $25 \mathrm{E}-12$

3. $56 \mathrm{E}-13$

1. $37 \mathrm{E}-13$

1. $15 \mathrm{E}-12$

$3.37 \mathrm{E}-07$ 
Apr 4, 2000 11:10 am

SUMMARY

Page 5

INDIVIDUAL EFEECTIVE.DOSE EQUIVALENT RATE (mrem/y)

(All Radionuclides and Pathways)

\begin{tabular}{|c|c|c|c|c|c|c|c|}
\hline \multirow[b]{2}{*}{ Direction } & \multicolumn{7}{|c|}{ Distance (m) } \\
\hline & 8550 & 9270 & 10980 & 11120 & 12250 & 12300 & 12440 \\
\hline $\mathbf{N}$ & $1.6 \mathrm{E}-02$ & $1.6 \mathrm{E}-02$ & $1.6 \mathrm{E}-02$ & $1.6 \mathrm{E}-02$ & $1.6 \mathrm{E}-02$ & $1.6 \mathrm{E}-02$ & 1. $6 \mathrm{E}-02$ \\
\hline NNW & $1.7 \mathrm{E}-02$ & $1.6 \mathrm{E}-02$ & $1.6 E-02$ & $1.6 \mathrm{E}-02$ & 1. $6 \mathrm{E}-02$ & $1.6 \mathrm{E}-02$ & 1. $6 \mathrm{E}-02$ \\
\hline NW & $1.7 E-02$ & $1.6 \mathrm{E}-02$ & $1.6 \mathrm{E}-02$ & $1.6 \mathrm{E}-02$ & $1.6 \mathrm{E}-02$ & $1.6 \mathrm{E}-02$ & $1.6 \mathrm{E}-02$ \\
\hline WNW & $1.6 \mathrm{E}-02$ & $1.6 \mathrm{E}-02$ & $1.6 \mathrm{E}-02$ & $1.6 \mathrm{E}-02$ & $1.6 \mathrm{E}-02$ & $1.6 \mathrm{E}-02$ & 1. $6 \mathrm{E}-02$ \\
\hline w & 1. $6 E-02$ & $1.6 \mathrm{E}-02$ & $1.6 \mathrm{E}-02$ & $1.6 \mathrm{E}-02$ & $1.6 \mathrm{E}-02$ & $1.6 \mathrm{E}-02$ & $1.6 E-02$ \\
\hline WSW & 1. $6 \mathrm{E}-02$ & $1.6 \mathrm{E}-02$ & $1.6 \mathrm{E}-02$ & $1.6 \mathrm{E}-02$ & $1.5 E-02$ & $1.5 \mathrm{E}-02$ & $1.5 \mathrm{E}-02$ \\
\hline SW & $1.6 \mathrm{E}-02$ & 1. $6 \mathrm{E}-02$ & 1. $6 \mathrm{E}-02$ & 1. $6 \mathrm{E}-02$ & $1.6 \mathrm{E}-02$ & $1.6 \mathrm{E}-02$ & $1.5 E-02$ \\
\hline SSW & $1.6 \mathrm{E}-02$ & $1.6 \mathrm{E}-02$ & $1.6 \mathrm{E}-02$ & $1.6 \mathrm{E}-02$ & $1.6 \mathrm{E}-02$ & $1.6 \mathrm{E}-02$ & $1.6 \mathrm{E}-02$ \\
\hline$S$ & $1.6 \mathrm{E}-02$ & 1. $6 \mathrm{E}-02$ & $1.6 \mathrm{E}-02$ & $1.6 \mathrm{E}-02$ & 1. $6 \mathrm{E}-02$ & $1.6 \mathrm{E}-02$ & 1. $6 \mathrm{E}-02$ \\
\hline SSE & 1. $6 \mathrm{E}-02$ & $1.6 \mathrm{E}-02$ & $1.6 \mathrm{E}-02$ & $1.6 \mathrm{E}-02$ & $1.6 \mathrm{E}-02$ & $1.6 \mathrm{E}-02$ & $1.6 \mathrm{E}-02$ \\
\hline $\mathrm{SE}$ & $1.7 E-02$ & $1.7 \mathrm{E}-02$ & $1.7 E-02$ & $1.7 E-02$ & $1.7 \mathrm{E}-02$ & $1.7 \mathrm{E}-02$ & $1.7 \mathrm{E}-02$ \\
\hline ESE & $1.9 \mathrm{E}-02$ & 1. $9 \mathrm{E}-02$ & $1.8 \mathrm{E}-02$ & $1.8 \mathrm{E}-02$ & $1.8 \mathrm{E}-02$ & $1.8 E-02$ & $1.8 E-02$ \\
\hline E & $1.8 \mathrm{E}-02$ & $1.8 \mathrm{E}-02$ & $1.7 \mathrm{E}-02$ & $1.7 \mathrm{E}-02$ & $1.7 \mathrm{E}-02$ & $1.7 \mathrm{E}-02$ & $1.7 \mathrm{E}-02$ \\
\hline ENE & $1.7 \mathrm{E}-02$ & $1.7 \mathrm{E}-02$ & $1.6 \mathrm{E}-02$ & $1.6 \mathrm{E}-02$ & $1.6 E-02$ & $1.6 \mathrm{E}-02$ & 1. $6 \mathrm{E}-02$ \\
\hline $\mathrm{NE}$ & $1.6 \mathrm{E}-02$ & $1.6 \mathrm{E}-02$ & $1.6 \mathrm{E}-02$ & $1.6 \mathrm{E}-02$ & $1.6 \mathrm{E}-02$ & 1. $6 \mathrm{E}-02$ & $1.6 \mathrm{E}-02$ \\
\hline \multirow[t]{2}{*}{ NNE } & 1. $6 \mathrm{E}-02$ & 1. $6 E-02$ & 1. $6 \mathrm{E}-02$ & $1.6 \mathrm{E}-02$ & $1.6 \mathrm{E}-02$ & 1. $6 \mathrm{E}-02$ & 1. $6 \mathrm{E}-02$ \\
\hline & \multicolumn{7}{|c|}{ Distance (m) } \\
\hline Direction & 12520 & 12920 & 12930 & 13010 & 13110 & 13490 & 15470 \\
\hline $\mathrm{N}$ & $1.6 \mathrm{E}-02$ & $1.6 \mathrm{E}-02$ & $1.6 \mathrm{E}-02$ & $1.6 \mathrm{E}-02$ & $1.6 \mathrm{E}-02$ & $1.6 \mathrm{E}-02$ & 1. $6 \mathrm{E}-02$ \\
\hline NNW & $1.6 \mathrm{E}-02$ & $1.6 \mathrm{E}-02$ & $1.6 \mathrm{E}-02$ & $1.6 \mathrm{E}-02$ & $1.6 \mathrm{E}-02$ & $1.6 \mathrm{E}-02$ & $1.6 \mathrm{E}-02$ \\
\hline NW & $1.6 \mathrm{E}-02$ & $1.6 \mathrm{E}-02$ & $1.6 \mathrm{E}-02$ & $1.6 \mathrm{E}-02$ & $1.6 \mathrm{E}-02$ & 1. $6 \mathrm{E}-02$ & 1. $6 \mathrm{E}-02$ \\
\hline WNW & 1. $6 \mathrm{E}-02$ & 1. $6 \mathrm{E}-02$ & $1.6 \mathrm{E}-02$ & $1.6 \mathrm{E}-02$ & $1.6 \mathrm{E}-02$ & 1. $6 \mathrm{E}-02$ & 1. $6 \mathrm{E}-02$ \\
\hline W & $1.6 \mathrm{E}-02$ & $1.6 \mathrm{E}-02$ & $1.6 \mathrm{E}-02$ & $1.6 \mathrm{E}-02$ & $1.6 \mathrm{E}-02$ & 1. $6 \mathrm{E}-02$ & $1.5 \mathrm{E}-02$ \\
\hline Wsw & $1.5 \mathrm{E}-02$ & 1. $5 E-02$ & $1.5 E-02$ & $1.5 \mathrm{E}-02$ & $1.5 \mathrm{E}-02$ & $1.5 \mathrm{E}-02$ & $1.5 \mathrm{E}-02$ \\
\hline SW & $1.5 \mathrm{E}-02$ & $1.5 \mathrm{E}-02$ & $1.5 \mathrm{E}-02$ & $1.5 \mathrm{E}-02$ & $1.5 \mathrm{E}-02$ & $1.5 \mathrm{E}-02$ & $1.5 E-02$ \\
\hline SSW & 1. $6 \mathrm{E}-02$ & $1.5 \mathrm{E}-02$ & $1.5 \mathrm{E}-02$ & $1.5 \mathrm{E}-02$ & $1.5 E-02$ & 1. $5 E-02$ & $1.5 \mathrm{E}-02$ \\
\hline $\mathrm{S}$ & $1.6 \mathrm{E}-02$ & $1.6 E-02$ & $1.6 \mathrm{E}-02$ & $1.6 E-02$ & $1.6 \mathrm{E}-02$ & $1.6 \mathrm{E}-02$ & $1.5 \mathrm{E}-02$ \\
\hline SSE & $1.6 \mathrm{E}-02$ & $1.6 \mathrm{E}-02$ & $1.6 \mathrm{E}-02$ & $1.6 \mathrm{E}-02$ & $1.6 \mathrm{E}-02$ & $1.6 \mathrm{E}-02$ & 1. $6 \mathrm{E}-02$ \\
\hline$S E$ & $1.6 \mathrm{E}-02$ & $1.6 \mathrm{E}-02$ & $1.6 \mathrm{E}-02$ & $1.6 \mathrm{E}-02$ & $1.6 \mathrm{E}-02$ & 1. $6 \mathrm{E}-02$ & $1.6 \mathrm{E}-02$ \\
\hline ESE & $1.8 \mathrm{E}-02$ & $1.8 \mathrm{E}-02$ & $1.8 \mathrm{E}-02$ & $1.8 \mathrm{E}-02$ & $1.8 \mathrm{E}-02$ & $1.7 \mathrm{E}-02$ & $1.7 \mathrm{E}-02$ \\
\hline$E$ & $1.7 \mathrm{E}-02$ & $1.7 \mathrm{E}-02$ & $1.7 \mathrm{E}-02$ & $1.7 \mathrm{E}-02$ & $1.7 \mathrm{E}-02$ & $1.7 \mathrm{E}-02$ & 1. $6 \mathrm{E}-02$ \\
\hline ENE & $1.6 \mathrm{E}-02$ & $1.6 \mathrm{E}-02$ & $1.6 \mathrm{E}-02$ & $1.6 \mathrm{E}-02$ & $1.6 \mathrm{E}-02$ & $1.6 \mathrm{E}-02$ & $1.6 \mathrm{E}-02$ \\
\hline NE & $1.6 \mathrm{E}-02$ & $1.6 \mathrm{E}-02$ & $1.6 \mathrm{E}-02$ & $1.6 \mathrm{E}-02$ & $1.6 \mathrm{E}-02$ & $1.6 \mathrm{E}-02$ & 1. $6 \mathrm{E}-02$ \\
\hline NNE & $1.6 E-02$ & 1. $6 \mathrm{E}-02$ & $1.6 \mathrm{E}-02$ & $1.6 \mathrm{E}-02$ & $1.6 \mathrm{E}-02$ & $1.6 \mathrm{E}-02$ & 1. $5 \mathrm{E}-02$ \\
\hline
\end{tabular}


DOE/ORP-2000-05, Rev. 1

$04 / 2000$

Apr 4, 2000 11:10 am

SUMMARY

Page 6

INDIVIDUAL EFFECTIVE .DOSE EQUIVALENT RATE (mrem/y)

(All Radionuclides and Pathways)

Distance $(m)$

\begin{tabular}{rrrr}
\cline { 3 - 4 } Direction & 16170 & 16600 & 19270 \\
\hline$N$ & $1.6 \mathrm{E}-02$ & $1.6 \mathrm{E}-02$ & $1.5 \mathrm{E}-02$ \\
$\mathrm{~N} W$ & $1.6 \mathrm{E}-02$ & $1.6 \mathrm{E}-02$ & $1.6 \mathrm{E}-02$ \\
$\mathrm{NW}$ & $1.6 \mathrm{E}-02$ & $1.6 \mathrm{E}-02$ & $1.6 \mathrm{E}-02$ \\
WNW & $1.6 \mathrm{E}-02$ & $1.6 \mathrm{E}-02$ & $1.5 \mathrm{E}-02$ \\
$\mathrm{~W}$ & $1.5 \mathrm{E}-02$ & $1.5 \mathrm{E}-02$ & $1.5 \mathrm{E}-02$ \\
$\mathrm{WSW}$ & $1.5 \mathrm{E}-02$ & $1.5 \mathrm{E}-02$ & $1.5 \mathrm{E}-02$ \\
$\mathrm{SW}$ & $1.5 \mathrm{E}-02$ & $1.5 \mathrm{E}-02$ & $1.5 \mathrm{E}-02$ \\
$\mathrm{SSW}$ & $1.5 \mathrm{E}-02$ & $1.5 \mathrm{E}-02$ & $1.5 \mathrm{E}-02$ \\
$\mathrm{~S}$ & $1.5 \mathrm{E}-02$ & $1.5 \mathrm{E}-02$ & $1.5 \mathrm{E}-02$ \\
$\mathrm{SSE}$ & $1.6 \mathrm{E}-02$ & $1.6 \mathrm{E}-02$ & $1.5 \mathrm{E}-02$ \\
$\mathrm{SE}$ & $1.6 \mathrm{E}-02$ & $1.6 \mathrm{E}-02$ & $1.6 \mathrm{E}-02$ \\
$\mathrm{ESE}$ & $1.7 \mathrm{E}-02$ & $1.7 \mathrm{E}-02$ & $1.7 \mathrm{E}-02$ \\
$\mathrm{E}$ & $1.6 \mathrm{E}-02$ & $1.6 \mathrm{E}-02$ & $1.6 \mathrm{E}-02$ \\
$\mathrm{ENE}$ & $1.6 \mathrm{E}-02$ & $1.6 \mathrm{E}-02$ & $1.6 \mathrm{E}-02$ \\
$\mathrm{NE}$ & $1.6 \mathrm{E}-02$ & $1.6 \mathrm{E}-02$ & $1.5 \mathrm{E}-02$ \\
$\mathrm{NNE}$ & $1.5 \mathrm{E}-02$ & $1.5 \mathrm{E}-02$ & $1.5 \mathrm{E}-02$ \\
\hline
\end{tabular}


DOE/ORP-2000-05, Rev. 1

Apr 4, 2000 11:10 am

SUMMARY

Page 7

INDIVIDUAL LIFETIME RISK (deaths)

(All Radionuclides and Pathways)

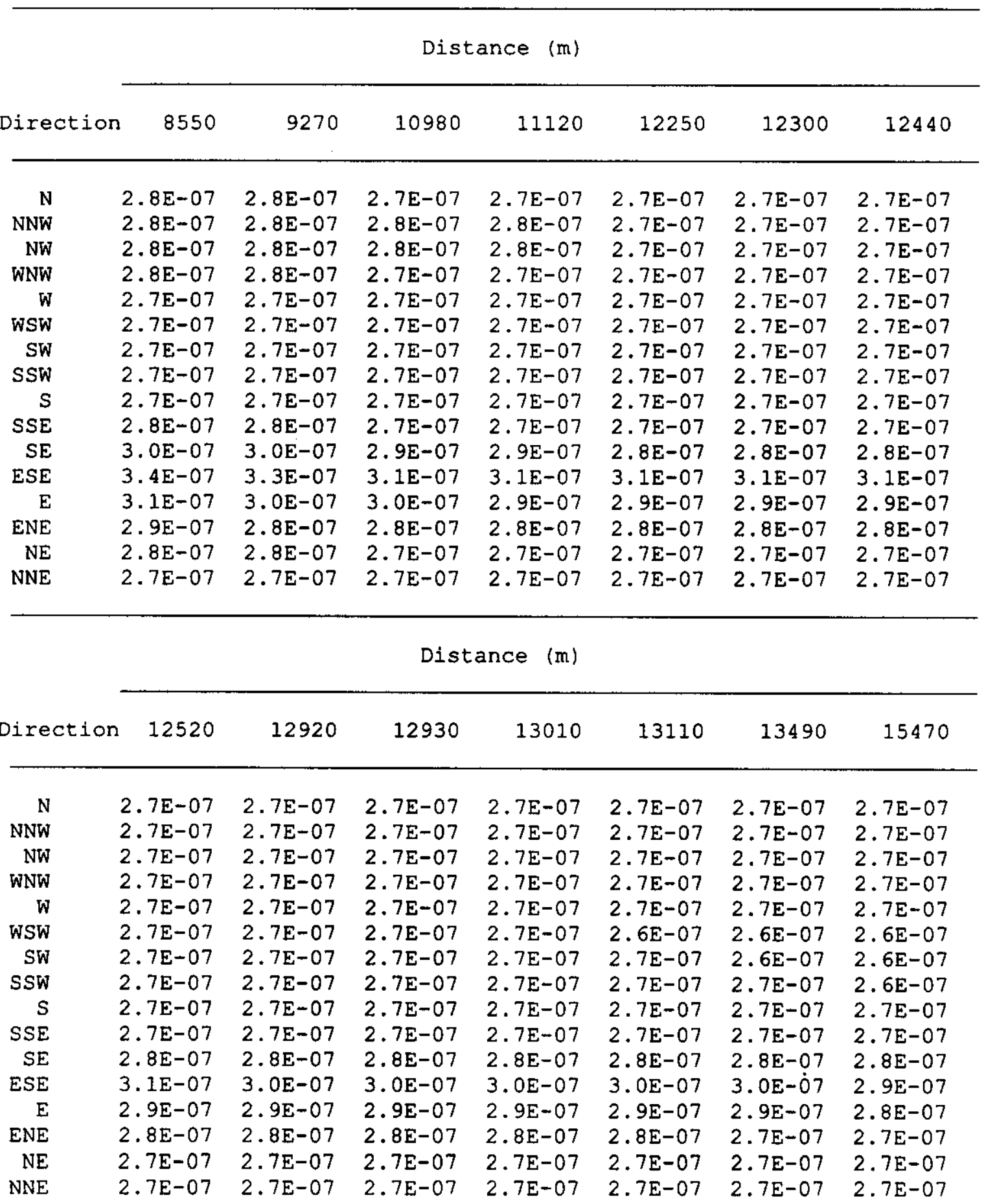


Apr 4, 2000 11:10 am

SUMMARY

Page 8

INDIVIDUAL LIFETIME RISK (deaths)

(All Radionuclides and Pathways)

\begin{tabular}{|c|c|c|c|c|}
\hline \multirow[b]{2}{*}{ Direction } & \multicolumn{4}{|c|}{ Distance (m) } \\
\hline & 16170 & 16600 & 19270 & \\
\hline $\mathrm{N}$ & $2.7 E-07$ & $2.7 E-07$ & $2.7 E-07$ & \\
\hline NNW & $2.7 E-07$ & $2.7 E-07$ & $2.7 E-07$ & \\
\hline NW & $2.7 E-07$ & $2.7 E-07$ & $2.7 E-07$ & \\
\hline WNW & $2.7 \mathrm{E}-07$ & $2.7 E-07$ & $2.6 \mathrm{E}-07$ & \\
\hline W & $2.6 E-07$ & $2.6 E-07$ & $2.6 E-07$ & \\
\hline WSW & $2.6 E-07$ & 2. $6 E-07$ & $2.6 E-07$ & \\
\hline SW & $2.6 \mathrm{E}-07$ & $2.6 E-07$ & $2.6 \mathrm{E}-07$ & \\
\hline SSW & $2.6 E-07$ & $2.6 E-07$ & $2.6 E-07$ & \\
\hline S & $2.6 \mathrm{E}-07$ & $2.6 \mathrm{E}-07$ & 2. $6 \mathrm{E}-07$ & \\
\hline SSE & $2.7 E-07$ & $2.7 E-07$ & $2.6 E-07$ & \\
\hline SE & $2.8 \mathrm{E}-07$ & $2.8 E-07$ & $2.7 E-07$ & \\
\hline ESE & 2. $9 E-07$ & 2. $9 \mathrm{E}-07$ & $2.9 E-07$ & \\
\hline E & $2.8 \mathrm{E}-07$ & $2.8 \mathrm{E}-07$ & $2.8 E-07$ & \\
\hline ENE & $2.7 E-07$ & $2.7 E-07$ & $2.7 E-07$ & \\
\hline NE & $2.7 E-07$ & $2.7 E-07$ & $2.7 E-07$ & . \\
\hline NNE & $2.7 \mathrm{E}-07$ & $2.6 \mathrm{E}-07$ & $2.6 \mathrm{E}-07$ & \\
\hline
\end{tabular}




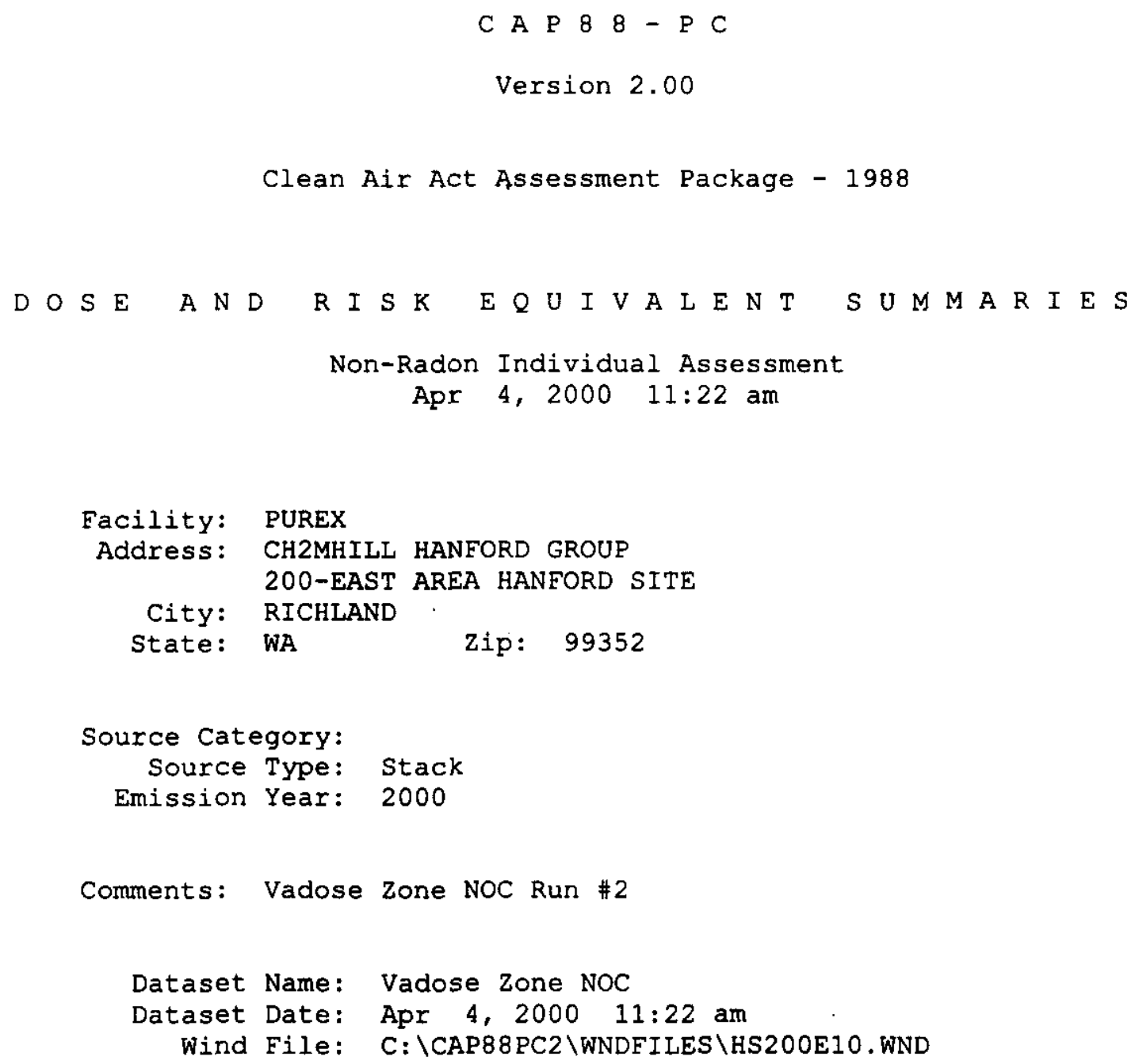




\begin{tabular}{lc} 
ORGAN DOSE EQUIVALENT SUMMARY \\
Organ & $\begin{array}{c}\text { Selected } \\
\text { Individual } \\
\text { (mrem/y) }\end{array}$ \\
\cline { 2 - 2 } GONADS & $1.30 \mathrm{E}-02$ \\
BREAST & $1.35 \mathrm{E}-03$ \\
R MAR & $8.35 \mathrm{E}-02$ \\
LUNGS & $6.25 \mathrm{E}-01$ \\
THYROID & $1.31 \mathrm{E}-03$ \\
ENDOST & $1.03 \mathrm{E}+00$ \\
RMNDR & $4.65 \mathrm{E}-02$ \\
EFFEC & $1.33 \mathrm{E}-01$
\end{tabular}

PATHWAY EFEECTIVE DOSE EQUIVALENT SUMMARY

Selected Individual

Pathway

INGESTION

INHALATION

AIR IMMERSION

GROUND SURFACE

INTERNAL

EXTERNAL

TOTAL
2. $21 \mathrm{E}-03$

1. 31E-01

3. $85 E-10$

1. $91 \mathrm{E}-05$

1. 33E-01

1. $91 \mathrm{E}-05$

1. $33 \mathrm{E}-01$ 


$\begin{array}{lc}\text { NUCLIDE EFFECTIVE DOSE EQUIVALENT SUMMARY } \\ \text { Nuclide } & \begin{array}{c}\text { Selected } \\ \text { Individual } \\ \text { (mrem/y) }\end{array} \\ \mathrm{U}-232 & 2.51 \mathrm{E}-06 \\ \mathrm{U}-233 & 2.69 \mathrm{E}-06 \\ \mathrm{U}-234 & 5.26 \mathrm{E}-05 \\ \mathrm{U}-235 & 2.20 \mathrm{E}-06 \\ \mathrm{U}-236 & 5.08 \mathrm{E}-07 \\ \mathrm{U}-238 & 4.71 \mathrm{E}-02 \\ \text { NP-237 } & 1.56 \mathrm{E}-06 \\ \text { PU-238 } & 6.27 \mathrm{E}-04 \\ \text { PU-239 } & 6.16 \mathrm{E}-02 \\ \text { PU-240 } & 6.48 \mathrm{E}-03 \\ \text { PU-241 } & 5.86 \mathrm{E}-04 \\ \text { PU-242 } & 1.75 \mathrm{E}-07 \\ \text { AM-241 } & 1.69 \mathrm{E}-02 \\ \text { AM-243 } & 3.74 \mathrm{E}-07 \\ \text { CM-242 } & 4.34 \mathrm{E}-06 \\ \text { CM-243 } & 3.09 \mathrm{E}-06 \\ \text { CM-244 } & 2.26 \mathrm{E}-05 \\ \text { TOTAL } & 1.33 \mathrm{E}-01\end{array}$


DOE/ORP-2000-05, Rev. 1

04/2000

Apr 4, 2000 11:22 am

SUMMARY

Page 3

CANCER RISK SUMMARY

\begin{tabular}{lc} 
Cancer & $\begin{array}{c}\text { Selected Individual } \\
\text { Total Lifetime } \\
\text { Fatal Cancer Risk }\end{array}$ \\
\cline { 2 - 2 } LEUKEMIA & $6.83 \mathrm{E}-08$ \\
BONE & $4.34 \mathrm{E}-08$ \\
THYROID & $1.44 \mathrm{E}-10$ \\
BREAST & $1.10 \mathrm{E}-09$ \\
LUNG & $1.01 \mathrm{E}-06$ \\
STOMACH & $7.83 \mathrm{E}-10$ \\
BOWEL & $5.32 \mathrm{E}-10$ \\
LIVER & $1.44 \mathrm{E}-07$ \\
PANCREAS & $5.77 \mathrm{E}-10$ \\
URINARY & $2.47 \mathrm{E}-09$ \\
OTHER & $7.06 \mathrm{E}-10$ \\
TOTAL & $1.27 \mathrm{E}-06$
\end{tabular}

PATHWAY RISK SUMMARY

Pathway

INGESTION

INHALATION

AIR IMMERSION

GROUND SURFACE

INTERNAL

EXTERNAL

TOTAL
Selected Individual Total Lifetime Fatal Cancer Risk

1. $10 \mathrm{E}-08$

1. 26E-06

8. $04 \mathrm{E}-15$

3. $99 \mathrm{E}-10$

1. $27 \mathrm{E}-06$

3. $99 \mathrm{E}-10$

1. $27 \mathrm{E}-06$ 
DOE/ORP-2000-05, Rev. 1

$04 / 2000$

Apr $4,2000 \quad 11: 22$ am

SUMMARY

Page 4

NUCLIDE RISK SUMMARY

Nuclide

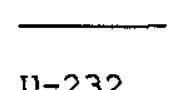

$\mathrm{U}-232$

U-233

U-234

$\mathrm{U}-235$

$\mathrm{U}-236$

$\mathrm{U}-238$

NP -237

PU -238

PU-239

PU-240

PU-241

PU-242

AM-241

$\mathrm{AM}-243$

$\mathrm{CM}-242$

$\mathrm{CM}-243$

$\mathrm{CM}-244$

TOTAL
Selected Individual

Total Lifetime

Fatal Cancer Risk

$2.06 \mathrm{E}-11$

3. $56 \mathrm{E}-11$

6. $95 \mathrm{E}-10$

2. $96 \mathrm{E}-11$

$6.72 \mathrm{E}-12$

$6.27 \mathrm{E}-07$

$7.89 \mathrm{E}-12$

5. $48 E-09$

4. $96 \mathrm{E}-07$

$5.22 E-08$

2. 24E-09

1. $40 \mathrm{E}-12$

8. $63 \mathrm{E}-08$

1. $91 \mathrm{E}-12$

6. $69 \mathrm{E}-11$

1. $86 \mathrm{E}-11$

1. $47 \mathrm{E}-10$

1. $27 \mathrm{E}-06$ 
INDIVIDUAL EFFECTIVE DOSE EQUIVALENT RATE (mrem/y) (All Radionuclides and Pathways)

\begin{tabular}{|c|c|c|c|c|c|c|c|}
\hline \multirow[b]{2}{*}{ Direction } & \multicolumn{6}{|c|}{ Distance (m) } & \multirow[b]{2}{*}{12440} \\
\hline & 8550 & 9270 & 10980 & 11120 & 12250 & 12300 & \\
\hline $\mathrm{N}$ & $3.4 \mathrm{E}-02$ & 3. $0 E-02$ & $2.4 \mathrm{E}-02$ & $2.4 \mathrm{E}-02$ & $2.1 E-02$ & $2.1 E-02$ & 2. $1 E-02$ \\
\hline NNW & $4.5 E-02$ & $4.0 E-02$ & 3. $2 \mathrm{E}-02$ & $3.1 E-02$ & $2.8 E-02$ & $2.8 E-02$ & $2.7 E-02$ \\
\hline NW & $4.4 \mathrm{E}-02$ & $3.9 E-02$ & $3.1 E-02$ & $3.0 E-02$ & $2.7 E-02$ & $2.7 E-02$ & $2.6 \mathrm{E}-02$ \\
\hline WNW & 3. $3 E-02$ & $2.9 E-02$ & 2. $3 E-02$ & $2.3 E-02$ & $2.0 E-02$ & $2.0 E-02$ & 2. $0 \mathrm{E}-02$ \\
\hline W & $2.7 \mathrm{E}-02$ & 2. $4 \mathrm{E}-02$ & 1. $9 \mathrm{E}-02$ & $1.9 \mathrm{E}-02$ & 1. $7 E-02$ & 1. $7 \mathrm{E}-02$ & $1.6 \mathrm{E}-02$ \\
\hline WSW & $2.1 \mathrm{E}-02$ & $1.8 E-02$ & 1. $5 \mathrm{E}-02$ & 1. $5 \mathrm{E}-02$ & 1. $3 E-02$ & 1. $3 E-02$ & 1. $3 E-02$ \\
\hline SW & 2. $2 \mathrm{E}-02$ & 1. $9 E-02$ & 1. $5 \mathrm{E}-02$ & 1. $5 \mathrm{E}-02$ & $1.4 \mathrm{E}-02$ & $1.3 \mathrm{E}-02$ & 1. $3 E-02$ \\
\hline SSW & 2. $2 \mathrm{E}-02$ & 1. $9 E-02$ & 1. $6 \mathrm{E}-02$ & $1.5 \mathrm{E}-02$ & 1. $4 \mathrm{E}-02$ & 1. $4 \mathrm{E}-02$ & $1.4 E-02$ \\
\hline S & $2.6 \mathrm{E}-02$ & 2. $3 E-02$ & 1. $8 \mathrm{E}-02$ & $1.8 E-02$ & 1. $6 E-02$ & 1. $6 \mathrm{E}-02$ & 1. $6 \mathrm{E}-02$ \\
\hline SSE & 3. $3 E-02$ & 2. $9 E-02$ & 2. $3 E-02$ & $2.3 E-02$ & 2. $0 E-02$ & $2.0 \mathrm{E}-02$ & $2.0 E-02$ \\
\hline$S E$ & 7. $3 E-02$ & $6.4 \mathrm{E}-02$ & $5.1 E-02$ & $5.0 E-02$ & $4.5 \mathrm{E}-02$ & $4.4 \mathrm{E}-02$ & $4.4 \mathrm{E}-02$ \\
\hline ESE & 1. $3 E-01$ & 1. $2 E-01$ & $9.4 \mathrm{E}-02$ & $9.2 E-02$ & $8.2 E-02$ & $8.2 \mathrm{E}-02$ & $8.1 E-02$ \\
\hline$E$ & $9.0 \mathrm{E}-02$ & 7. $9 E-02$ & $6.3 \mathrm{E}-02$ & $6.2 E-02$ & $5.5 \mathrm{E}-02$ & $5.5 E-02$ & $5.4 \mathrm{E}-02$ \\
\hline ENE & $5.1 E-02$ & $4.5 E-02$ & 3. $6 \mathrm{E}-02$ & 3. $6 E-02$ & 3. $2 \mathrm{E}-02$ & 3. $2 \mathrm{E}-02$ & $3.1 E-02$ \\
\hline $\mathrm{NE}$ & $3.4 \mathrm{E}-02$ & 3. $0 \mathrm{E}-02$ & $2.4 \mathrm{E}-02$ & $2.3 E-02$ & $2.1 E-02$ & $2.1 \mathrm{E}-02$ & $2.1 E-02$ \\
\hline NNE & $2.7 \mathrm{E}-02$ & $2.4 \mathrm{E}-02$ & 1. $9 E-02$ & 1. $9 \mathrm{E}-02$ & $1.7 E-02$ & $1.7 \mathrm{E}-02$ & $1.7 \mathrm{E}-02$ \\
\hline
\end{tabular}

Distance (m)

\begin{tabular}{rrrrrrrr} 
& & & & & & & \\
Direction & 12520 & 12920 & 12930 & 13010 & 13110 & 13490 & 15470 \\
\hline & & & & & & & \\
N & $2.1 \mathrm{E}-02$ & $2.0 \mathrm{E}-02$ & $2.0 \mathrm{E}-02$ & $2.0 \mathrm{E}-02$ & $2.0 \mathrm{E}-02$ & $1.9 \mathrm{E}-02$ & $1.6 \mathrm{E}-02$ \\
$\mathrm{NNW}$ & $2.7 \mathrm{E}-02$ & $2.6 \mathrm{E}-02$ & $2.6 \mathrm{E}-02$ & $2.6 \mathrm{E}-02$ & $2.6 \mathrm{E}-02$ & $2.5 \mathrm{E}-02$ & $2.1 \mathrm{E}-02$ \\
$\mathrm{NW}$ & $2.6 \mathrm{E}-02$ & $2.5 \mathrm{E}-02$ & $2.5 \mathrm{E}-02$ & $2.5 \mathrm{E}-02$ & $2.5 \mathrm{E}-02$ & $2.4 \mathrm{E}-02$ & $2.0 \mathrm{E}-02$ \\
WNW & $2.0 \mathrm{E}-02$ & $1.9 \mathrm{E}-02$ & $1.9 \mathrm{E}-02$ & $1.9 \mathrm{E}-02$ & $1.9 \mathrm{E}-02$ & $1.8 \mathrm{E}-02$ & $1.5 \mathrm{E}-02$ \\
$\mathrm{~W}$ & $1.6 \mathrm{E}-02$ & $1.6 \mathrm{E}-02$ & $1.6 \mathrm{E}-02$ & $1.6 \mathrm{E}-02$ & $1.5 \mathrm{E}-02$ & $1.5 \mathrm{E}-02$ & $1.3 \mathrm{E}-02$ \\
WSW & $1.3 \mathrm{E}-02$ & $1.2 \mathrm{E}-02$ & $1.2 \mathrm{E}-02$ & $1.2 \mathrm{E}-02$ & $1.2 \mathrm{E}-02$ & $1.2 \mathrm{E}-02$ & $1.0 \mathrm{E}-02$ \\
$\mathrm{SW}$ & $1.3 \mathrm{E}-02$ & $1.3 \mathrm{E}-02$ & $1.3 \mathrm{E}-02$ & $1.3 \mathrm{E}-02$ & $1.3 \mathrm{E}-02$ & $1.2 \mathrm{E}-02$ & $1.0 \mathrm{E}-02$ \\
$\mathrm{SSW}$ & $1.3 \mathrm{E}-02$ & $1.3 \mathrm{E}-02$ & $1.3 \mathrm{E}-02$ & $1.3 \mathrm{E}-02$ & $1.3 \mathrm{E}-02$ & $1.2 \mathrm{E}-02$ & $1.1 \mathrm{E}-02$ \\
$\mathrm{~S}$ & $1.6 \mathrm{E}-02$ & $1.5 \mathrm{E}-02$ & $1.5 \mathrm{E}-02$ & $1.5 \mathrm{E}-02$ & $1.5 \mathrm{E}-02$ & $1.4 \mathrm{E}-02$ & $1.2 \mathrm{E}-02$ \\
$\mathrm{SSE}$ & $2.0 \mathrm{E}-02$ & $1.9 \mathrm{E}-02$ & $1.9 \mathrm{E}-02$ & $1.9 \mathrm{E}-02$ & $1.9 \mathrm{E}-02$ & $1.8 \mathrm{E}-02$ & $1.5 \mathrm{E}-02$ \\
$\mathrm{SE}$ & $4.4 \mathrm{E}-02$ & $4.2 \mathrm{E}-02$ & $4.2 \mathrm{E}-02$ & $4.2 \mathrm{E}-02$ & $4.1 \mathrm{E}-02$ & $4.0 \mathrm{E}-02$ & $3.4 \mathrm{E}-02$ \\
$\mathrm{ESE}$ & $8.0 \mathrm{E}-02$ & $7.7 \mathrm{E}-02$ & $7.7 \mathrm{E}-02$ & $7.7 \mathrm{E}-02$ & $7.6 \mathrm{E}-02$ & $7.3 \mathrm{E}-02$ & $6.2 \mathrm{E}-02$ \\
$\mathrm{E}$ & $5.4 \mathrm{E}-02$ & $5.2 \mathrm{E}-02$ & $5.2 \mathrm{E}-02$ & $5.2 \mathrm{E}-02$ & $5.1 \mathrm{E}-02$ & $5.0 \mathrm{E}-02$ & $4.2 \mathrm{E}-02$ \\
$\mathrm{ENE}$ & $3.1 \mathrm{E}-02$ & $3.0 \mathrm{E}-02$ & $3.0 \mathrm{E}-02$ & $3.0 \mathrm{E}-02$ & $3.0 \mathrm{E}-02$ & $2.9 \mathrm{E}-02$ & $2.4 \mathrm{E}-02$ \\
$\mathrm{NE}$ & $2.1 \mathrm{E}-02$ & $2.0 \mathrm{E}-02$ & $2.0 \mathrm{E}-02$ & $2.0 \mathrm{E}-02$ & $2.0 \mathrm{E}-02$ & $1.9 \mathrm{E}-02$ & $1.6 \mathrm{E}-02$ \\
$\mathrm{NNE}$ & $1.6 \mathrm{E}-02$ & $1.6 \mathrm{E}-02$ & $1.6 \mathrm{E}-02$ & $1.6 \mathrm{E}-02$ & $1.6 \mathrm{E}-02$ & $1.5 \mathrm{E}-02$ & $1.3 \mathrm{E}-02$
\end{tabular}


DOE/ORP-2000-05, Rev. 1

$\begin{array}{llr}\text { Apr } 4,2000 & 11: 22 \text { am } & \text { SUMMARY } \\ & \text { Page } 6\end{array}$

INDIVIDUAL EFFECTIVE.DOSE EQUIVALENT RATE (mrem/y)

(All Radionuclides and Pathways)

\begin{tabular}{rlll}
\hline & & & Distance $(\mathrm{m})$ \\
& & & \\
\cline { 2 - 4 } Direction & 16170 & 16600 & 19270 \\
\hline & & & \\
$N$ & $1.5 \mathrm{E}-02$ & $1.5 \mathrm{E}-02$ & $1.3 \mathrm{E}-02$ \\
$\mathrm{NNW}$ & $2.0 \mathrm{E}-02$ & $2.0 \mathrm{E}-02$ & $1.6 \mathrm{E}-02$ \\
$\mathrm{NW}$ & $1.9 \mathrm{E}-02$ & $1.9 \mathrm{E}-02$ & $1.6 \mathrm{E}-02$ \\
WNW & $1.5 \mathrm{E}-02$ & $1.4 \mathrm{E}-02$ & $1.2 \mathrm{E}-02$ \\
$\mathrm{~W}$ & $1.2 \mathrm{E}-02$ & $1.2 \mathrm{E}-02$ & $9.8 \mathrm{E}-03$ \\
WSW & $9.5 \mathrm{E}-03$ & $9.3 \mathrm{E}-03$ & $7.8 \mathrm{E}-03$ \\
$\mathrm{SW}$ & $9.9 \mathrm{E}-03$ & $9.6 \mathrm{E}-03$ & $8.1 \mathrm{E}-03$ \\
$\mathrm{SSW}$ & $1.0 \mathrm{E}-02$ & $9.8 \mathrm{E}-03$ & $8.3 \mathrm{E}-03$ \\
$\mathrm{~S}$ & $1.2 \mathrm{E}-02$ & $1.1 \mathrm{E}-02$ & $9.5 \mathrm{E}-03$ \\
$\mathrm{SSE}$ & $1.5 \mathrm{E}-02$ & $1.4 \mathrm{E}-02$ & $1.2 \mathrm{E}-02$ \\
$\mathrm{SE}$ & $3.2 \mathrm{E}-02$ & $3.1 \mathrm{E}-02$ & $2.6 \mathrm{E}-02$ \\
$\mathrm{ESE}$ & $5.9 \mathrm{E}-02$ & $5.7 \mathrm{E}-02$ & $4.8 \mathrm{E}-02$ \\
$\mathrm{E}$ & $4.0 \mathrm{E}-02$ & $3.9 \mathrm{E}-02$ & $3.2 \mathrm{E}-02$ \\
$\mathrm{ENE}$ & $2.3 \mathrm{E}-02$ & $2.3 \mathrm{E}-02$ & $1.9 \mathrm{E}-02$ \\
$\mathrm{NE}$ & $1.5 \mathrm{E}-02$ & $1.5 \mathrm{E}-02$ & $1.3 \mathrm{E}-02$ \\
$\mathrm{NNE}$ & $1.2 \mathrm{E}-02$ & $1.2 \mathrm{E}-02$ & $1.0 \mathrm{E}-02$ \\
\hline
\end{tabular}


INDIVIDUAL LIFETIME RISK (deaths)

(All Radionuclides and Pathways)

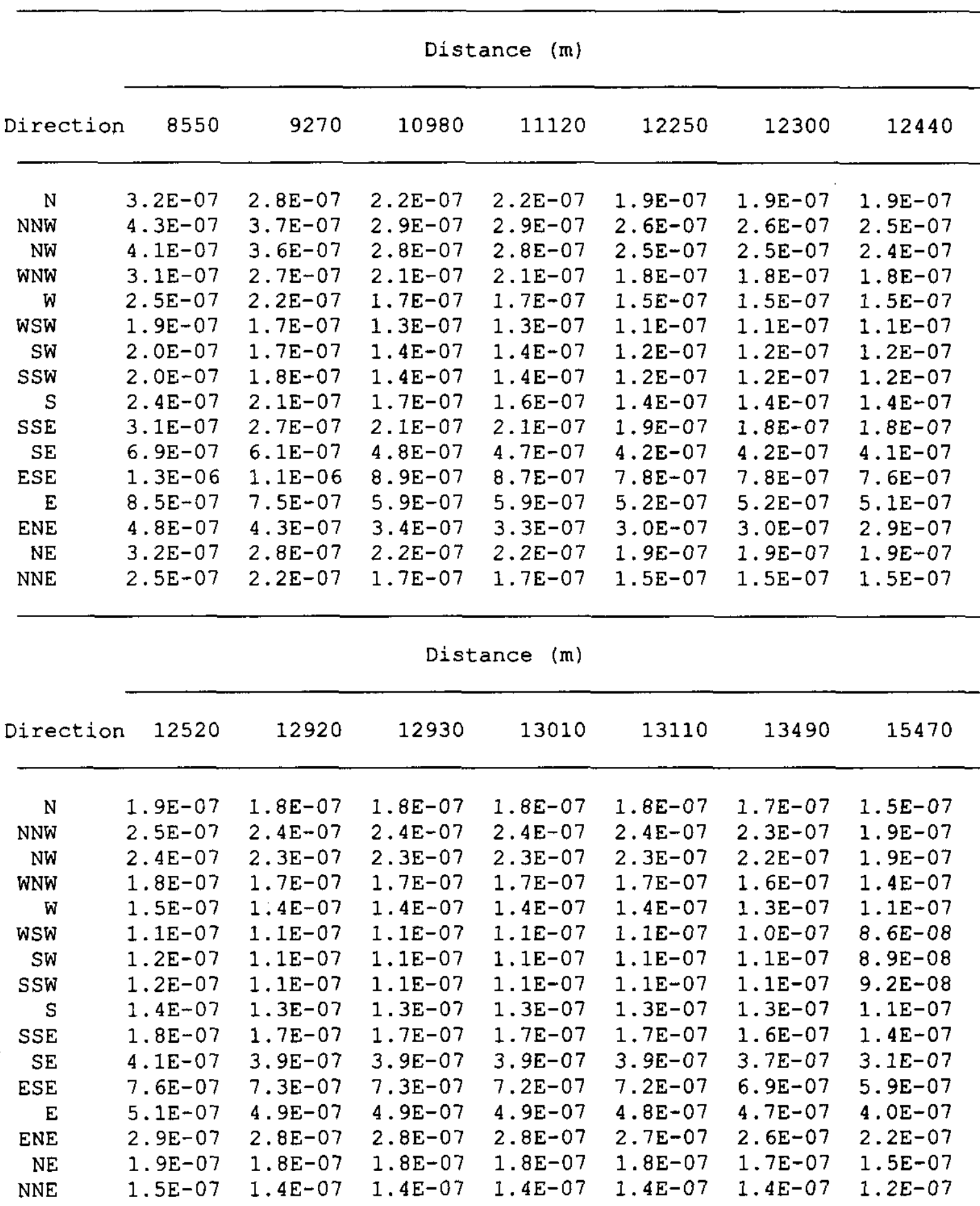


DOE/ORP-2000-05, Rev. 1

$04 / 2000$

Apr 4, 2000 11:22 am

SUMMARY

Page 8

INDIVIDUAL LIFETIME RISK (deaths)

(All Radionuclides and Pathways)

Distance (m)

\begin{tabular}{rrrr}
\cline { 2 - 4 } Direction & 16170 & 16600 & 19270 \\
\hline & & & \\
$N$ & $1.4 \mathrm{E}-07$ & $1.3 \mathrm{E}-07$ & $1.1 \mathrm{E}-07$ \\
$\mathrm{NNW}$ & $1.8 \mathrm{E}-07$ & $1.8 \mathrm{E}-07$ & $1.5 \mathrm{E}-07$ \\
$\mathrm{NW}$ & $1.7 \mathrm{E}-07$ & $1.7 \mathrm{E}-07$ & $1.4 \mathrm{E}-07$ \\
WNW & $1.3 \mathrm{E}-07$ & $1.3 \mathrm{E}-07$ & $1.0 \mathrm{E}-07$ \\
$\mathrm{~W}$ & $1.1 \mathrm{E}-07$ & $1.0 \mathrm{E}-07$ & $8.4 \mathrm{E}-08$ \\
$\mathrm{WSW}$ & $8.1 \mathrm{E}-08$ & $7.9 \mathrm{E}-08$ & $6.5 \mathrm{E}-08$ \\
$\mathrm{SW}$ & $8.5 \mathrm{E}-08$ & $8.2 \mathrm{E}-08$ & $6.8 \mathrm{E}-08$ \\
$\mathrm{SSW}$ & $8.7 \mathrm{E}-08$ & $8.4 \mathrm{E}-08$ & $7.0 \mathrm{E}-08$ \\
$\mathrm{~S}$ & $1.0 \mathrm{E}-07$ & $9.9 \mathrm{E}-08$ & $8.1 \mathrm{E}-08$ \\
$\mathrm{SSE}$ & $1.3 \mathrm{E}-07$ & $1.3 \mathrm{E}-07$ & $1.0 \mathrm{E}-07$ \\
$\mathrm{SE}$ & $3.0 \mathrm{E}-07$ & $2.9 \mathrm{E}-07$ & $2.4 \mathrm{E}-07$ \\
$\mathrm{ESE}$ & $5.6 \mathrm{E}-07$ & $5.4 \mathrm{E}-07$ & $4.5 \mathrm{E}-07$ \\
$\mathrm{E}$ & $3.7 \mathrm{E}-07$ & $3.6 \mathrm{E}-07$ & $3.0 \mathrm{E}-07$ \\
$\mathrm{ENE}$ & $2.1 \mathrm{E}-07$ & $2.1 \mathrm{E}-07$ & $1.7 \mathrm{E}-07$ \\
$\mathrm{NE}$ & $1.4 \mathrm{E}-07$ & $1.3 \mathrm{E}-07$ & $1.1 \mathrm{E}-07$ \\
$\mathrm{NNE}$ & $1.1 \mathrm{E}-07$ & $1.1 \mathrm{E}-07$ & $8.8 \mathrm{E}-08$ \\
\hline
\end{tabular}




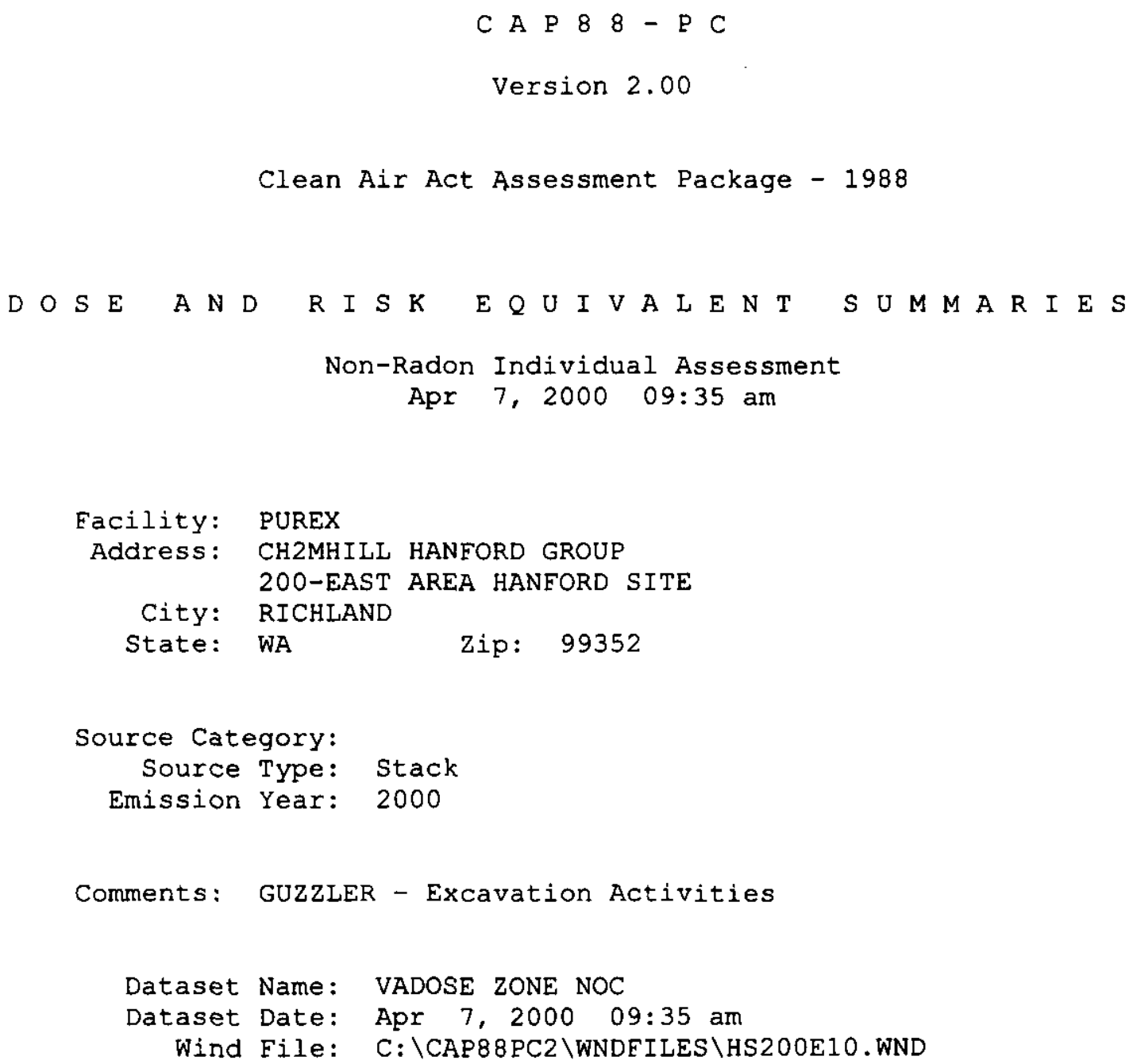


ORGAN DOSE EQUIVALENT SUMMARY

\begin{tabular}{lc} 
Organ & $\begin{array}{c}\text { Selected } \\
\text { Individual } \\
\text { (mrem/y) }\end{array}$ \\
\hline GONADS & $3.35 \mathrm{E}-04$ \\
BREAST & $2.00 \mathrm{E}-04$ \\
R MAR & $2.34 \mathrm{E}-02$ \\
LUNGS & $3.01 \mathrm{E}-04$ \\
THYROID & $1.99 \mathrm{E}-04$ \\
ENDOST & $6.13 \mathrm{E}-02$ \\
RMNDR & $1.13 \mathrm{E}-03$ \\
EFFEC & $5.14 \mathrm{E}-03$
\end{tabular}

PATHWAY EFFECTIVE DOSE EQUIVALENT SUMMARY

Pathway

INGESTION INHALATION AIR IMMERSION GROUND SUREACE INTERNAL EXTERNAI

TOTAL
Selected Individual (mrem/y)

$3.51 \mathrm{E}-03$

$1.63 \mathrm{E}-03$

1.39E-11

$5.41 \mathrm{E}-07$

$5.14 \mathrm{E}-03$

$5.41 E-07$

$5.14 \mathrm{E}-03$ 
Apr 7, 2000 09:35 am

SUMMARY

Page 2

NUCLIDE EFEECTIVE DOSE EQUIVALENT SUMMARY

\begin{tabular}{lc} 
Nuclide & $\begin{array}{c}\text { Selected } \\
\text { Individual } \\
\text { (mrem/y) }\end{array}$ \\
\hline $\begin{array}{l}\text { AM-241 } \\
\text { SR-90 }\end{array}$ & $6.72 \mathrm{E}-04$ \\
TOTAL & $4.47 \mathrm{E}-03$ \\
& $5.14 \mathrm{E}-03$
\end{tabular}


CANCER RISK SUMMARY

\begin{tabular}{lc} 
Cancer & $\begin{array}{c}\text { Selected Individual } \\
\text { Total Lifetime } \\
\text { Fatal Cancer Risk }\end{array}$ \\
\hline LEUKEMIA & $6.36 \mathrm{E}-08$ \\
BONE & $7.56 \mathrm{E}-09$ \\
THYROID & $8.31 \mathrm{E}-11$ \\
BREAST & $7.04 \mathrm{E}-10$ \\
LUNG & $1.28 \mathrm{E}-09$ \\
STOMACH & $3.76 \mathrm{E}-10$ \\
BOWEL & $1.67 \mathrm{E}-09$ \\
LIVER & $2.46 \mathrm{E}-09$ \\
PANCREAS & $4.38 \mathrm{E}-10$ \\
URINARY & $2.25 \mathrm{E}-10$ \\
OTHER & $5.35 \mathrm{E}-10$ \\
TOTAL & $7.89 \mathrm{E}-08$
\end{tabular}

PATHWAY RISK SUMMARY

Pathway

INGESTION

INHALATION

AIR IMMERSION

GROUND SURFACE

INTERNAL

EXTERNAL

TOTAL
Selected Individual Total Lifetime Fatal Cancer Risk

$5.90 E-08$

1. $99 \mathrm{E}-08$

2. $88 \mathrm{E}-16$

1. $13 \mathrm{E}-11$

7. $89 \mathrm{E}-08$

1. $13 \mathrm{E}-11$

$7.89 \mathrm{E}-08$ 
Apr 7, 2000 09:35 am

SUMMARY

Page 4

NUCLIDE RISK SUMMARY

\begin{tabular}{lc} 
Nuclide & $\begin{array}{c}\text { Selected Individual } \\
\text { Total Lifetime } \\
\text { Fatal Cancer Risk }\end{array}$ \\
\hline AM-241 & $3.44 \mathrm{E}-09$ \\
SR-90 & $7.55 \mathrm{E}-08$ \\
TOTAL & $7.89 \mathrm{E}-08$
\end{tabular}


Apr 7, 2000 09:35 am

SUMMARY

Page 5

INDIVIDUAL EFFECTIVE.DOSE EQUIVALENT RATE (mrem/y)

(All Radionuclides and Pathways)

\begin{tabular}{|c|c|c|c|c|c|c|c|}
\hline \multirow[b]{2}{*}{ Direction } & \multicolumn{7}{|c|}{ Distance (m) } \\
\hline & 8550 & 9270 & 10980 & 11120 & 12250 & 12300 & 12440 \\
\hline $\begin{array}{r}N \\
N N W \\
N W \\
W N W \\
W \\
W S W \\
S W \\
\text { SSW } \\
S \\
\text { SSE } \\
S E \\
E S E \\
E \\
\text { ENE } \\
N E \\
N N E\end{array}$ & $\begin{array}{l}3.9 E-03 \\
4.0 \mathrm{E}-03 \\
4.0 \mathrm{E}-03 \\
3.9 \mathrm{E}-03 \\
3.8 \mathrm{E}-03 \\
3.7 \mathrm{E}-03 \\
3.8 \mathrm{E}-03 \\
3.8 \mathrm{E}-03 \\
3.8 \mathrm{E}-03 \\
3.9 \mathrm{E}-03 \\
4.4 \mathrm{E}-03 \\
5.1 \mathrm{E}-03 \\
4.6 \mathrm{E}-03 \\
4.1 \mathrm{E}-03 \\
3.9 \mathrm{E}-03 \\
3.8 \mathrm{E}-03\end{array}$ & $\begin{array}{l}3.9 \mathrm{E}-03 \\
4.0 \mathrm{E}-03 \\
4.0 \mathrm{E}-03 \\
3.8 \mathrm{E}-03 \\
3.8 \mathrm{E}-03 \\
3.7 \mathrm{E}-03 \\
3.7 \mathrm{E}-03 \\
3.7 \mathrm{E}-03 \\
3.8 \mathrm{E}-03 \\
3.8 \mathrm{E}-03 \\
4.3 \mathrm{E}-03 \\
4.9 \mathrm{E}-03 \\
4.5 \mathrm{E}-03 \\
4.0 \mathrm{E}-03 \\
3.9 \mathrm{E}-03 \\
3.8 \mathrm{E}-03\end{array}$ & $\begin{array}{l}3.8 E-03 \\
3.9 E-03 \\
3.9 E-03 \\
3.8 E-03 \\
3.7 E-03 \\
3.7 E-03 \\
3.7 E-03 \\
3.7 E-03 \\
3.7 E-03 \\
3.8 E-03 \\
4.1 E-03 \\
4.6 E-03 \\
4.3 E-03 \\
3.9 E-03 \\
3.8 E-03 \\
3.7 E-03\end{array}$ & $\begin{array}{l}3.8 E-03 \\
3.9 E-03 \\
3.9 E-03 \\
3.8 E-03 \\
3.7 E-03 \\
3.7 E-03 \\
3.7 E-03 \\
3.7 E-03 \\
3.7 E-03 \\
3.8 E-03 \\
4.1 E-03 \\
4.6 E-03 \\
4.3 E-03 \\
3.9 E-03 \\
3.8 E-03 \\
3.7 E-03\end{array}$ & $\begin{array}{l}3.7 \mathrm{E}-03 \\
3.8 \mathrm{E}-03 \\
3.8 \mathrm{E}-03 \\
3.7 \mathrm{E}-03 \\
3.7 \mathrm{E}-03 \\
3.6 \mathrm{E}-03 \\
3.7 \mathrm{E}-03 \\
3.7 \mathrm{E}-03 \\
3.7 \mathrm{E}-03 \\
3.7 \mathrm{E}-03 \\
4.0 \mathrm{E}-03 \\
4.5 \mathrm{E}-03 \\
4.2 \mathrm{E}-03 \\
3.9 \mathrm{E}-03 \\
3.7 \mathrm{E}-03 \\
3.7 \mathrm{E}-03\end{array}$ & $\begin{array}{l}3.7 E-03 \\
3.8 E-03 \\
3.8 E-03 \\
3.7 E-03 \\
3.7 E-03 \\
3.6 E-03 \\
3.6 E-03 \\
3.7 E-03 \\
3.7 E-03 \\
3.7 E-03 \\
4.0 E-03 \\
4.5 E-03 \\
4.2 E-03 \\
3.9 E-03 \\
3.7 E-03 \\
3.7 E-03\end{array}$ & $\begin{array}{l}3.7 E-03 \\
3.8 E-03 \\
3.8 E-03 \\
3.7 E-03 \\
3.7 E-03 \\
3.6 E-03 \\
3.6 E-03 \\
3.7 E-03 \\
3.7 E-03 \\
3.7 E-03 \\
4.0 E-03 \\
4.5 E-03 \\
4.2 E-03 \\
3.9 E-03 \\
3.7 E-03 \\
3.7 E-03\end{array}$ \\
\hline \multicolumn{8}{|c|}{ Distance (m) } \\
\hline Direction & 12520 & 12920 & 12930 & 13010 & 13110 & 13490 & 15470 \\
\hline $\mathrm{N}$ & $3.7 E-03$ & $3.7 E-03$ & $3.7 \mathrm{E}-03$ & $3.7 E-03$ & $3.7 \mathrm{E}-03$ & $3.7 E-03$ & $3.7 E-03$ \\
\hline NNW & 3. $8 \mathrm{E}-03$ & 3. $8 \mathrm{E}-03$ & 3. $8 E-03$ & 3. $8 E-03$ & 3. $8 E-03$ & $3.8 \mathrm{E}-03$ & 3. $7 \mathrm{E}-03$ \\
\hline $\begin{array}{l}\text { NW } \\
\text { WNW }\end{array}$ & $\begin{array}{l}3.8 E-03 \\
3.7 E-03\end{array}$ & $\begin{array}{l}3.8 E-03 \\
3.7 E-03\end{array}$ & $\begin{array}{l}3.8 E-03 \\
3.7 E-03\end{array}$ & $\begin{array}{l}3.8 E-03 \\
3.7 E-03\end{array}$ & $\begin{array}{l}3.8 E-03 \\
3.7 E-03\end{array}$ & $\begin{array}{l}3.8 E-03 \\
3.7 E-03\end{array}$ & $\begin{array}{l}3.7 E-03 \\
3.7 E-03\end{array}$ \\
\hline$w$ & $3.7 \mathrm{E}-03$ & $3.7 \mathrm{E}-03$ & $3.7 E-03$ & $3.7 \mathrm{E}-03$ & $3.7 \mathrm{E}-03$ & $3.7 \mathrm{E}-03$ & $3.6 \mathrm{E}-03$ \\
\hline WSW & 3. $6 \mathrm{E}-03$ & $3.6 E-03$ & 3. $6 \mathrm{E}-03$ & $3.6 \mathrm{E}-03$ & $3.6 \mathrm{E}-03$ & $3.6 \mathrm{E}-03$ & $3.6 E-03$ \\
\hline SW & $3.6 \mathrm{E}-03$ & $3.6 \mathrm{E}-03$ & $3.6 \mathrm{E}-03$ & $3.6 \mathrm{E}-03$ & $3.6 \mathrm{E}-03$ & $3.6 \mathrm{E}-03$ & $3.6 \mathrm{E}-03$ \\
\hline SSW & $3.6 \mathrm{E}-03$ & 3. $6 E-03$ & $3.6 \mathrm{E}-03$ & 3. $6 E-03$ & $3.6 \mathrm{E}-03$ & 3. $6 E-03$ & $3.6 E-03$ \\
\hline$S$ & $3.7 E-03$ & $3.7 \mathrm{E}-03$ & $3.7 \mathrm{E}-03$ & $3.7 \mathrm{E}-03$ & $3.7 E-03$ & $3.7 E-03$ & $3.6 E-03$ \\
\hline SSE & $3.7 \mathrm{E}-03$ & $3.7 \mathrm{E}-03$ & $3.7 \mathrm{E}-03$ & $3.7 E-03$ & $3.7 E-03$ & $3.7 E-03$ & $3.7 E-03$ \\
\hline$S E$ & $4.0 E-03$ & 4. $0 E-03$ & $4.0 E-03$ & 4. OE -03 & $4.0 E-03$ & 4. $0 E-03$ & $3.9 E-03$ \\
\hline ESE & $4.5 E-03$ & $4.4 E-03$ & $4.4 E-03$ & 4. $4 \mathrm{E}-03$ & $4.4 \mathrm{E}-03$ & $4.4 E-03$ & $4.3 E-03$ \\
\hline$E$ & $4.2 \mathrm{E}-03$ & $4.1 E-03$ & $4.1 \mathrm{E}-03$ & $4.1 \mathrm{E}-03$ & $4.1 E-03$ & $4.1 E-03$ & $4.0 \mathrm{E}-03$ \\
\hline ENE & $3.9 E-03$ & $3.9 E-03$ & $3.9 E-03$ & $3.9 E-03$ & $3.8 \mathrm{E}-03$ & $3.8 E-03$ & $3.8 E-03$ \\
\hline $\mathrm{NE}$ & $3.7 \mathrm{E}-03$ & $3.7 \mathrm{E}-03$ & $3.7 E-03$ & $3.7 E-03$ & $3.7 E-03$ & $3.7 \mathrm{E}-03$ & $3.7 \mathrm{E}-03$ \\
\hline NNE & $3.7 E-03$ & $3.7 E \sim 03$ & $3.7 \mathrm{E}-03$ & $3.7 E-03$ & $3.7 E-03$ & $3.7 \mathrm{E}-03$ & $3.6 E-03$ \\
\hline
\end{tabular}


Apr 7, 2000 09:35 am

SUMMARY

Page 6

INDIVIDUAL EFFECTIVE .DOSE EQUIVALENT RATE (mrem/y)

(All Radionuclides and Pathways)

\begin{tabular}{rlll}
\hline & & & \\
& & & \\
& & & \\
Direction & 16170 & 16600 & 19270 \\
& & & \\
\hline$N$ & $3.7 E-03$ & $3.7 E-03$ & $3.6 \mathrm{E}-03$ \\
$\mathrm{~N} W$ & $3.7 \mathrm{E}-03$ & $3.7 \mathrm{E}-03$ & $3.7 \mathrm{E}-03$ \\
$\mathrm{NW}$ & $3.7 \mathrm{E}-03$ & $3.7 \mathrm{E}-03$ & $3.7 \mathrm{E}-03$ \\
$\mathrm{WNW}$ & $3.7 \mathrm{E}-03$ & $3.7 \mathrm{E}-03$ & $3.6 \mathrm{E}-03$ \\
$\mathrm{~W}$ & $3.6 \mathrm{E}-03$ & $3.6 \mathrm{E}-03$ & $3.6 \mathrm{E}-03$ \\
$\mathrm{WSW}$ & $3.6 \mathrm{E}-03$ & $3.6 \mathrm{E}-03$ & $3.6 \mathrm{E}-03$ \\
$\mathrm{SW}$ & $3.6 \mathrm{E}-03$ & $3.6 \mathrm{E}-03$ & $3.6 \mathrm{E}-03$ \\
$\mathrm{SSW}$ & $3.6 \mathrm{E}-03$ & $3.6 \mathrm{E}-03$ & $3.6 \mathrm{E}-03$ \\
$\mathrm{~S}$ & $3.6 \mathrm{E}-03$ & $3.6 \mathrm{E}-03$ & $3.6 \mathrm{E}-03$ \\
$\mathrm{SSE}$ & $3.7 \mathrm{E}-03$ & $3.7 \mathrm{E}-03$ & $3.6 \mathrm{E}-03$ \\
$\mathrm{SE}$ & $3.9 \mathrm{E}-03$ & $3.9 \mathrm{E}-03$ & $3.8 \mathrm{E}-03$ \\
$\mathrm{ESE}$ & $4.2 \mathrm{E}-03$ & $4.2 \mathrm{E}-03$ & $4.1 \mathrm{E}-03$ \\
$\mathrm{E}$ & $4.0 \mathrm{E}-03$ & $4.0 \mathrm{E}-03$ & $3.9 \mathrm{E}-03$ \\
$\mathrm{ENE}$ & $3.8 \mathrm{E}-03$ & $3.8 \mathrm{E}-03$ & $3.7 \mathrm{E}-03$ \\
$\mathrm{NE}$ & $3.7 \mathrm{E}-03$ & $3.7 \mathrm{E}-03$ & $3.6 \mathrm{E}-03$ \\
$\mathrm{NNE}$ & $3.6 \mathrm{E}-03$ & $3.6 \mathrm{E}-03$ & $3.6 \mathrm{E}-03$ \\
\hline
\end{tabular}


DOE/ORP-2000-05, Rev. 1

$04 / 2000$

Apr 7, 2000 09:35 am

SUMMARY

Page 7

INDIVIDUAL LIFETIME RISK (deaths)

(All Radionuclides and Pathways)

\begin{tabular}{|c|c|c|c|c|c|c|c|}
\hline \multirow[b]{2}{*}{ Direction } & \multicolumn{7}{|c|}{ Distance (m) } \\
\hline & 8550 & 9270 & 10980 & 11120 & 12250 & 12300 & 12440 \\
\hline $\mathrm{N}$ & $6.4 \mathrm{E}-08$ & $6.3 E-08$ & $6.2 E-08$ & $6.2 \mathrm{E}-08$ & $6.2 E-08$ & $6.2 \mathrm{E}-08$ & $6.2 E-08$ \\
\hline NNW & $6.6 E-08$ & $6.5 E-08$ & $6.3 E-08$ & $6.3 E-08$ & $6.3 E-08$ & $6.3 E-08$ & $6.3 E-08$ \\
\hline $\mathrm{NW}$ & $6.5 \mathrm{E}-08$ & $6.5 E-08$ & $6.3 E-08$ & $6.3 E-08$ & $6.3 E-08$ & $6.3 E-08$ & $6.3 E-08$ \\
\hline WNW & $6.4 \mathrm{E}-08$ & $6.3 E-08$ & $6.2 E-08$ & $6.2 E-08$ & $6.2 E-08$ & $6.2 \mathrm{E}-08$ & $6.2 E-08$ \\
\hline W & $6.3 E-08$ & $6.2 E-08$ & $6.2 E-08$ & $6.1 \mathrm{E}-08$ & $6.1 E-08$ & $6.1 E-08$ & $6.1 E-08$ \\
\hline WSW & $6.2 E-08$ & $6.1 E-08$ & $6.1 E-08$ & $6.1 E-08$ & $6.1 E-08$ & $6.1 E-08$ & $6.1 E-08$ \\
\hline SW & $6.2 \mathrm{E}-08$ & $6.2 \mathrm{E}-08$ & $6.1 E-08$ & $6.1 \mathrm{E}-08$ & $6.1 E-08$ & $6.1 \mathrm{E}-08$ & $6.1 E-08$ \\
\hline SSW & $6.2 E-08$ & $6.2 \mathrm{E}-08$ & $6.1 E-08$ & $6.1 E-08$ & $6.1 \mathrm{E}-08$ & $6.1 E-08$ & $6.1 E-08$ \\
\hline$S$ & $6.3 E-08$ & $6.2 \mathrm{E}-08$ & $6.1 E-08$ & $6.1 \mathrm{E}-08$ & $6.1 E-08$ & $6.1 E-08$ & $6.1 E-08$ \\
\hline SSE & $6.4 \mathrm{E}-08$ & $6.3 E-08$ & $6.2 \mathrm{E}-08$ & $6.2 \mathrm{E}-08$ & $6.2 E-08$ & $6.2 E-08$ & $6.2 E-08$ \\
\hline$S E$ & $7.0 E-08$ & $6.8 E-08$ & $6.6 \mathrm{E}-08$ & $6.6 \mathrm{E}-08$ & $6.5 E-08$ & $6.5 \mathrm{E}-08$ & $6.5 E-08$ \\
\hline ESE & $7.9 E-08$ & $7.7 \mathrm{E}-08$ & 7. $3 \mathrm{E}-08$ & $7.3 E-08$ & $7.1 \mathrm{E}-08$ & $7.1 E-08$ & $7.1 \mathrm{E}-08$ \\
\hline $\mathrm{E}$ & 7. $2 E-08$ & $7.1 E-08$ & $6.8 \mathrm{E}-08$ & $6.8 E-08$ & $6.7 \mathrm{E}-08$ & $6.7 \mathrm{E}-08$ & $6.7 E-08$ \\
\hline ENE & $6.6 E-08$ & $6.6 \mathrm{E}-08$ & $6.4 \mathrm{E}-08$ & $6.4 \mathrm{E}-08$ & $6.3 E-08$ & $6.3 E-08$ & $6.3 E-08$ \\
\hline $\mathrm{NE}$ & $6.4 \mathrm{E}-08$ & $6.3 E-08$ & $6.2 \mathrm{E}-08$ & $6.2 E-08$ & $6.2 E-08$ & $6.2 E-08$ & $6.2 E-08$ \\
\hline NNE & $6.3 E-08$ & $6.2 E-08$ & $6.2 \mathrm{E}-08$ & $6.1 E-08$ & $6.1 E-08$ & $6.1 E-08$ & $6.1 E-08$ \\
\hline
\end{tabular}

Distance (m)

\begin{tabular}{|c|c|c|c|c|c|c|c|}
\hline Direction & 12520 & 12920 & 12930 & 13010 & 13110 & 13490 & 15470 \\
\hline $\mathrm{N}$ & $6.2 E-08$ & $6.2 E-08$ & $6.2 \mathrm{E}-08$ & $6.2 \mathrm{E}-08$ & $6.2 E-08$ & $6.2 E-08$ & $6.1 E-08$ \\
\hline NNW & $6.3 E-08$ & $6.3 E-08$ & $6.3 \mathrm{E}-08$ & 6. $3 E-08$ & $6.3 E-08$ & $6.2 E-08$ & $6.2 E-08$ \\
\hline NW & $6.3 E-08$ & $6.2 E-08$ & $6.2 \mathrm{E}-08$ & $6.2 E-08$ & $6.2 E-08$ & $6.2 E-08$ & $6.2 E-08$ \\
\hline WNW & $6.2 \mathrm{E}-08$ & $6.2 E-08$ & $6.2 \mathrm{E}-08$ & $6.1 E-08$ & $6.1 E-08$ & $6.1 E-08$ & $6.1 E-08$ \\
\hline W & $6.1 \mathrm{E}-08$ & $6.1 E-08$ & $6.1 E-08$ & $6.1 E-08$ & $6.1 \mathrm{E}-08$ & $6.1 E-08$ & $6.1 E-08$ \\
\hline WSW & $6.1 \mathrm{E}-08$ & $6.0 \mathrm{E}-08$ & 6. $0 \mathrm{E}-08$ & $6.0 E-08$ & $6.0 \mathrm{E}-08$ & $6.0 \mathrm{E}-08$ & $6.0 E-08$ \\
\hline SW & $6.1 E-08$ & $6.1 E-08$ & $6.1 E-08$ & $6.1 E-08$ & $6.1 E-08$ & $6.0 \mathrm{E}-08$ & $6.0 E-08$ \\
\hline SSW & $6.1 \mathrm{E}-08$ & $6.1 \mathrm{E}-08$ & $6.1 \mathrm{E}-08$ & $6.1 E-08$ & $6.1 E-08$ & $6.0 E-08$ & $6.0 E-08$ \\
\hline S & $6.1 E-08$ & $6.1 E-08$ & $6.1 \mathrm{E}-08$ & $6.1 E-08$ & $6.1 E-08$ & $6.1 E-08$ & $6.0 \mathrm{E}-08$ \\
\hline SSE & $6.2 E-08$ & $6.2 \mathrm{E}-08$ & $6.2 E-08$ & $6.2 \mathrm{E}-08$ & $6.1 E-08$ & $6.1 \mathrm{E}-08$ & $6.1 E-08$ \\
\hline SE & $6.5 E-08$ & $6.5 E-08$ & $6.5 E-08$ & $6.5 E-08$ & $6.5 \mathrm{E}-08$ & $6.5 E-08$ & $6.4 \mathrm{E}-08$ \\
\hline ESE & 7. $1 \mathrm{E}-08$ & $7.0 E-08$ & $7.0 \mathrm{E}-08$ & $7.0 \mathrm{E}-08$ & $7.0 \mathrm{E}-08$ & $7.0 \mathrm{E}-08$ & $6.8 E-08$ \\
\hline$E$ & $6.7 E-08$ & $6.7 E-08$ & $6.7 E-08$ & $6.6 \mathrm{E}-08$ & $6.6 \mathrm{E}-08$ & $6.6 \mathrm{E}-08$ & $6.5 E-08$ \\
\hline ENE & $6.3 E-08$ & $6.3 E-08$ & $6.3 E-08$ & $6.3 E-08$ & $6.3 E-08$ & $6.3 E-08$ & $6.2 E-08$ \\
\hline - NE & $6.2 E-08$ & $6.2 \mathrm{E}-08$ & $6.2 \mathrm{E}-08$ & $6.2 \mathrm{E}-08$ & $6.2 \mathrm{E}-08$ & $6.1 E-08$ & $6.1 \mathrm{E}-08$ \\
\hline NNE & $6.1 \mathrm{E}-08$ & $6.1 E-08$ & $6.1 \mathrm{E}-08$ & $6.1 E-08$ & $6.1 E-08$ & $6.1 E-08$ & $6.1 E-08$ \\
\hline
\end{tabular}


DOE/ORP-2000-05, Rev. 1

04/2000

Apr 7, 2000 09:35 am

SUMMARY

Page 8

INDIVIDUAL LIFETIME RISK (deaths)

(All Radionuclides and Pathways)

\begin{tabular}{rlll}
\hline & & & Distance $(\mathrm{m})$ \\
& & & \\
\cline { 2 - 4 } Direction & 16170 & 16600 & 19270 \\
\hline & & & \\
$N$ & $6.1 \mathrm{E}-08$ & $6.1 \mathrm{E}-08$ & $6.1 \mathrm{E}-08$ \\
$\mathrm{~N} W$ & $6.2 \mathrm{E}-08$ & $6.2 \mathrm{E}-08$ & $6.1 \mathrm{E}-08$ \\
$\mathrm{NW}$ & $6.2 \mathrm{E}-08$ & $6.1 \mathrm{E}-08$ & $6.1 \mathrm{E}-08$ \\
WNW & $6.1 \mathrm{E}-08$ & $6.1 \mathrm{E}-08$ & $6.0 \mathrm{E}-08$ \\
$\mathrm{~W}$ & $6.0 \mathrm{E}-08$ & $6.0 \mathrm{E}-08$ & $6.0 \mathrm{E}-08$ \\
WSW & $6.0 \mathrm{E}-08$ & $6.0 \mathrm{E}-08$ & $6.0 \mathrm{E}-08$ \\
$\mathrm{SW}$ & $6.0 \mathrm{E}-08$ & $6.0 \mathrm{E}-08$ & $6.0 \mathrm{E}-08$ \\
$\mathrm{SSW}$ & $6.0 \mathrm{E}-08$ & $6.0 \mathrm{E}-08$ & $6.0 \mathrm{E}-08$ \\
$\mathrm{~S}$ & $6.0 \mathrm{E}-08$ & $6.0 \mathrm{E}-08$ & $6.0 \mathrm{E}-08$ \\
$\mathrm{SSE}$ & $6.1 \mathrm{E}-08$ & $6.1 \mathrm{E}-08$ & $6.0 \mathrm{E}-08$ \\
$\mathrm{SE}$ & $6.3 \mathrm{E}-08$ & $6.3 \mathrm{E}-08$ & $6.3 \mathrm{E}-08$ \\
$\mathrm{ESE}$ & $6.8 \mathrm{E}-08$ & $6.7 \mathrm{E}-08$ & $6.6 \mathrm{E}-08$ \\
$\mathrm{E}$ & $6.5 \mathrm{E}-08$ & $6.5 \mathrm{E}-08$ & $6.4 \mathrm{E}-08$ \\
$\mathrm{ENE}$ & $6.2 \mathrm{E}-08$ & $6.2 \mathrm{E}-08$ & $6.1 \mathrm{E}-08$ \\
$\mathrm{NE}$ & $6.1 \mathrm{E}-08$ & $6.1 \mathrm{E}-08$ & $6.1 \mathrm{E}-08$ \\
$\mathrm{NNE}$ & $6.1 \mathrm{E}-08$ & $6.0 \mathrm{E}-08$ & $6.0 \mathrm{E}-08$ \\
& & & \\
\hline
\end{tabular}




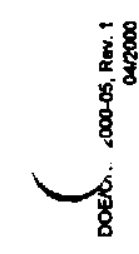

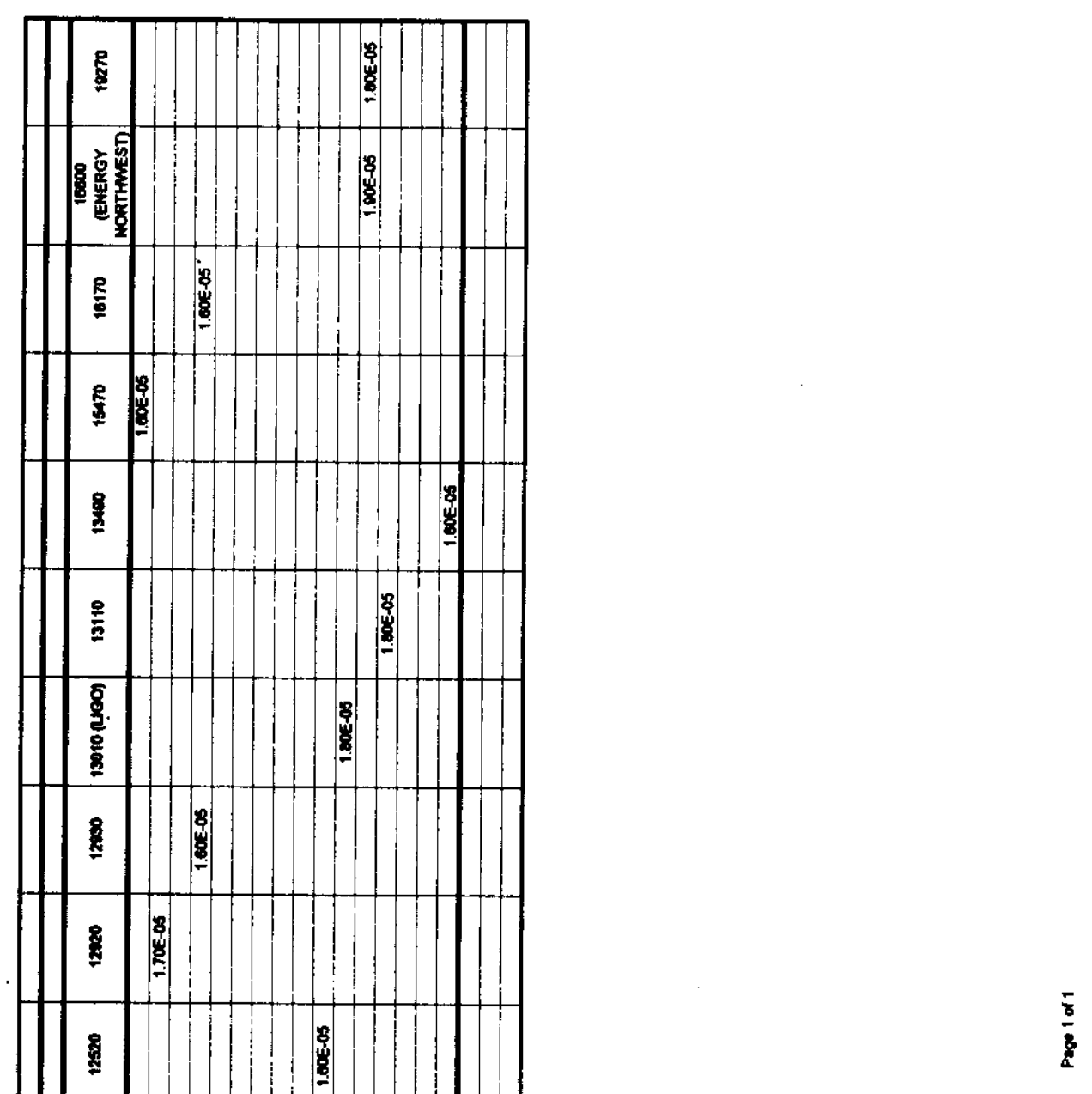


I

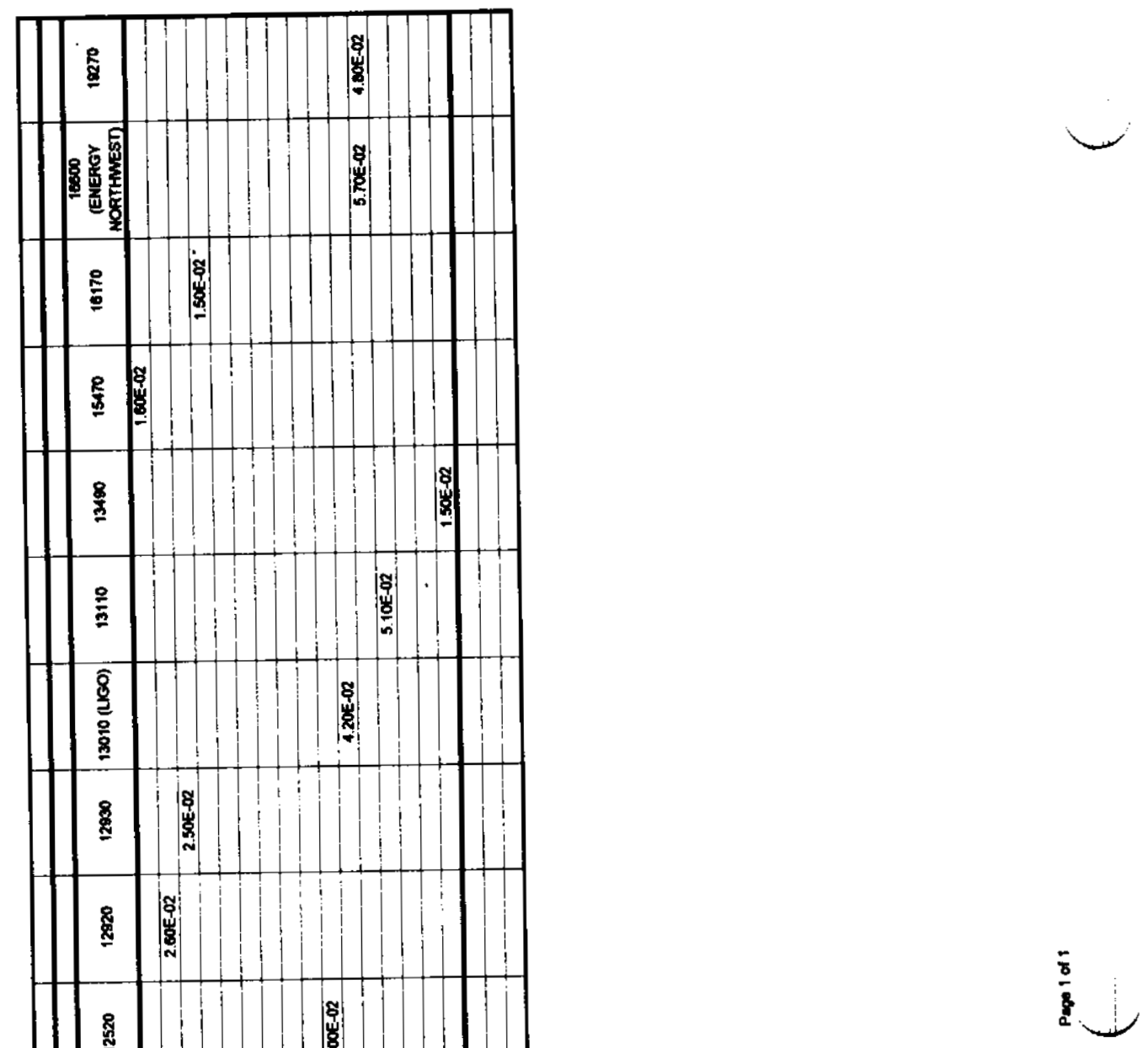


-8
8
8
8
8
8
8
0
0
0
0
8
8

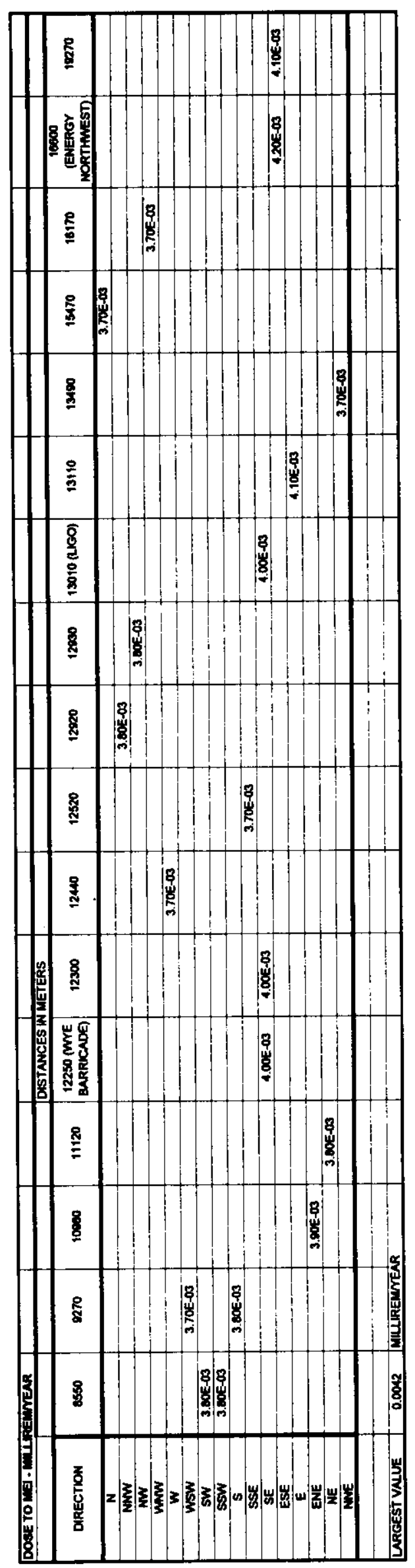

$\frac{5}{8}$ 


\section{DISTRIBUTION}

MSIN

J. Leitch

United States Environmental Protection Agency

Region 10

1200 Sixth Avenue

Seattle, Washington, 98101

A. W. Conklin

Washington State Department of Health

7171 Cleanwater Lane, Building 5

Olympia, Washington 98504

R. S. Acselrod

Washington State Department of Health

PMB 385

2839 W. Kennewick, Avenue

Kennewick, Washington 99336

J. W. Schmidt

Washington State Department of Health

PMB 385

2839 W. Kennewick, Avenue

Kennewick, Washington 99336

J. Wilkinson

Confederated Tribes of the Umatilla Indian Nation

P. O. Box 638

Pendleton, Oregon 97801

P. Sobotta

Nez Perce Tribe

P. O. Box 365

Lapwai, Idaho 93540

R. Jim, Manager

Environmental Restoration/Waste Management Program Yakama Nation

P. O. Box 151

Toppenish, Washington 98948

U.S. Department of Energy, Office of River Protection

J. J. Bevelacqua

H6-60

D. W. Bowser

H6-60

J. A. Poppiti

H6-60

R. T. Winward

H6-60

R. M. Yasek

H6-60

Public Reading Room

$\mathrm{H} 2-53$

Distr-1 


\section{DISTRIBUTION}

MSIN

U.S. Department of Energy, Richland Operations Office

S. E. Clarke

A6-38

D. M. Collado

A5-17

D. E. Olson

A5-13

J. E. Rasmussen

A2-15

CH2M HILL Hanford Group, Inc.

D. J. Carrell

R1-51

D. E. Clark

R1-51

B. G. Erlandson

R1-51

C. C. Haass

R2-89

M. S. Harrington

R2-88

J. S. Hill

R1-51

D. G, Larsen

T4-08

J. J. Luke

R1-51

P. C. Miller

R1-51

D. A. Myers (10)

H0-22

Numatec Hanford Corp.

C. M. Lewis

H0-22

Pacific Northwest National Laboratory

Hanford Technical Library

P8-55

Fluor Federal Services

F. M. Mann

H0-22

Fluor Hanford

B. L. Curn

Gl-30

Waste Management Northwest, Inc.

M. G. Gardner

H]-11

D. J. Moak

H1-11

K. D. Reynolds

H1-11

Lockheed Martin Services, Inc.

Central Files

B1-07

DPC

H6-08

EDMC (2)

H6-08 